San Jose State University

SJSU ScholarWorks

Master's Theses

Master's Theses and Graduate Research

Spring 2017

\title{
Using Stable Isotope Analysis to Infer Breeding Latitude and Migratory Timing of Juvenile Pacific-Slope Flycatchers (Empidonax Diffıcilis)
}

Emily Bailey Moffitt

San Jose State University

Follow this and additional works at: https://scholarworks.sjsu.edu/etd_theses

\section{Recommended Citation}

Moffitt, Emily Bailey, "Using Stable Isotope Analysis to Infer Breeding Latitude and Migratory Timing of Juvenile Pacific-Slope Flycatchers (Empidonax Difficilis)" (2017). Master's Theses. 4812.

DOI: https://doi.org/10.31979/etd.2k8t-xmu5

https://scholarworks.sjsu.edu/etd_theses/4812

This Thesis is brought to you for free and open access by the Master's Theses and Graduate Research at SJSU ScholarWorks. It has been accepted for inclusion in Master's Theses by an authorized administrator of SJSU ScholarWorks. For more information, please contact scholarworks@sjsu.edu. 


\title{
USING STABLE ISOTOPE ANALYSIS TO INFER BREEDING LATITUDE AND MIGRATORY TIMING OF JUVENILE PACIFIC-SLOPE FLYCATCHERS \\ (Empidonax difficilis)
}

\author{
A Thesis \\ Presented to \\ The Faculty of the Department of Environmental Studies \\ San José State University \\ In Partial Fulfillment \\ of the Requirements for the Degree \\ Master of Science
}

by

Emily B. Moffitt

May, 2017 
(C) 2017

Emily B. Moffitt

ALL RIGHTS RESERVED 
The Designated Thesis Committee Approves the Thesis Titled

USING STABLE ISOTOPE ANALYSIS TO INFER BREEDING LATITUDE AND MIGRATORY TIMING OF JUVENILE PACIFIC-SLOPE FLYCATCHERS

(Empidonax difficilis)

by

Emily B. Moffitt

APPROVED FOR THE DEPARTMENT OF ENVIRONMENTAL STUDIES

SAN JOSÉ STATE UNIVERSITY

May, 2017

Lynne Trulio, Ph.D.

Department of Environmental Studies

Scott Shaffer, Ph.D.

Department of Biological Sciences

Kristen Ruegg, Ph.D.

Research Biologist, University of

California, Santa Cruz 


\section{ABSTRACT \\ USING STABLE ISOTOPE ANALYSIS TO INFER BREEDING LATITUDE AND MIGRATORY TIMING OF JUVENILE PACIFIC-SLOPE FLYCATCHERS (Empidonax difficilis)}

by Emily B. Moffitt

Effective conservation of migratory species is hindered by a lack of knowledge of population links between breeding, wintering and stopover habitats. The Pacific-slope flycatcher (Empidonax difficilis) is one of the many Neotropical migratory songbirds whose populations are steadily declining throughout western North America. This research contributed to the assessment of connectivity in this species by inferring relative breeding origins and habitat selection of juvenile birds that migrate along the Pacific Flyway to the South San Francisco Bay Area in the fall. Feather data collected from July 20 to October 12, 2014 were analyzed for three stable isotopes $\left(\delta^{2} \mathrm{H}, \delta^{13} \mathrm{C}, \delta^{15} \mathrm{~N}\right)$. Findings revealed that populations migrated sequentially from western regions throughout expected breeding latitudes, with early season migrants most likely coming from the more southern, warmer, and dryer regions of northern California, Oregon, and southern Washington while late season migrants had probable origins in the more northern, cooler, and wetter regions of northern Washington and southwestern British Columbia. This study provided new information on the annual cycle and migratory timing of Pacific-slope flycatchers, and lays the foundation for future assessments of migratory connectivity of this species. 


\section{DEDICATION}

To the memory of my grandmother, Sigrid Richter Hoffman. Sigrid had a deep appreciation for the earth and animals and kept a garden that served as a sanctuary for birds on the wing. Her compassion for life's delicacies will always be remembered.

November 16, 1930 - October 15, 2016

I want to express my sincere appreciation and gratitude to all of the people that helped make the completion of this thesis possible. To my parents, my siblings, my best friend Julie, my family and friends: thank you for encouraging me to follow my dreams, for pushing me to succeed in academia, and for always listening to my bird stories.

Justin: you have been an incredibly patient, loving, and supportive partner through some of the most stressful aspects of this project; I am tremendously grateful that I've had you by my side.

To my thesis advisor, Dr. Lynne Trulio: I am incredibly thankful for your knowledge, advice, and willingness to support my research. You inspired me to follow my passion, and provided a consistent voice of reason. My committee members, Dr. Scott Shaffer and

Dr. Kristen Ruegg: your mentoring was invaluable to all aspects of my project- thank you for enlightening me about migratory connectivity and the utility of stable isotopes.

Thank you to the San Francisco Bay Bird Observatory, Josh Scullen, and the volunteer bird banders at the Coyote Creek Field Station for providing me with a venue and assistance for conducting this research. To all of my funders, laboratory assistants, statistical advisors, and peers - I am so grateful for all of you. 


\section{TABLE OF CONTENTS}

List of Tables.............................................................. viii

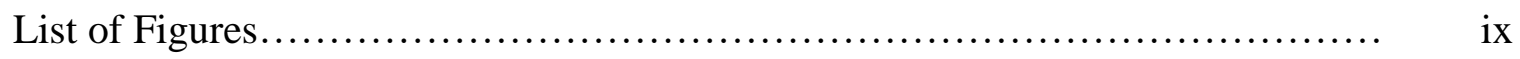

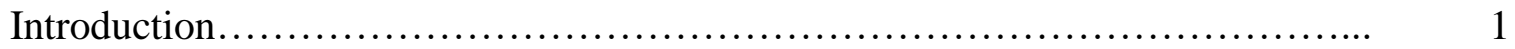

Threats to Migratory Birds............................................. 3

Pacific-slope flycatchers .............................................. 8

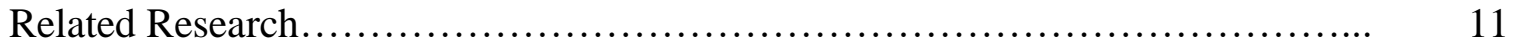

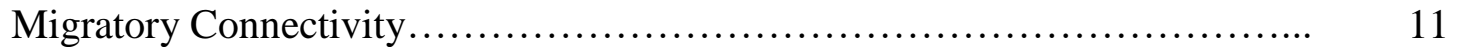

Research Methods.................................................. 12

Pacific-slope flycatchers............................................ 20

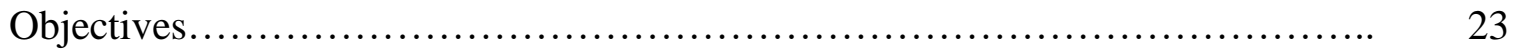

Research Questions................................................. 24

Null Hypotheses................................................... 24

Methods................................................................. 25

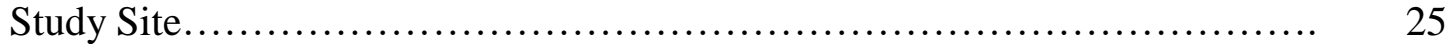

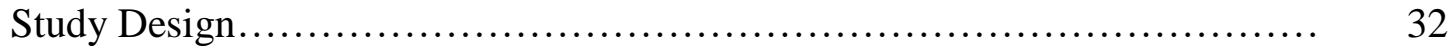

Data Collection...................................................... 34

Field procedures................................................... 34

Laboratory procedures............................................ $\quad 38$

Secondary data...................................................... 44

Data Analysis.......................................................... 47

Assignments to breeding origin.................................... 47

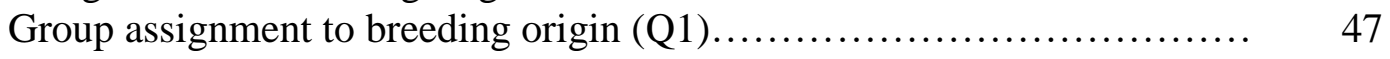

Incorporation of BBS Abundance Data (Q1) ........................ 54

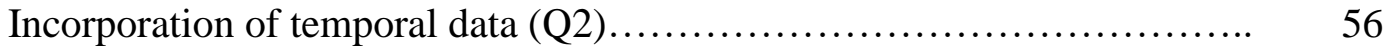

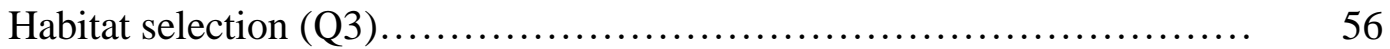

Morphological measurement analysis (Q4) .......................... $\quad 60$

Limitations............................................................. 61

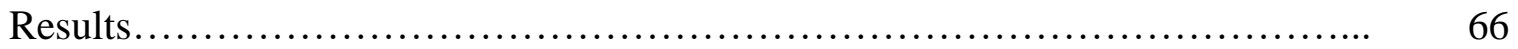

Probable Breeding Origins of Pacific-slope flycatchers....................... 66

Precision in hydrogen analysis...................................... 66

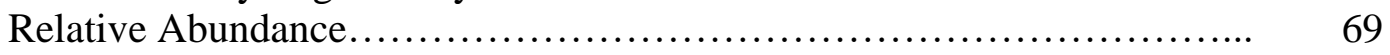

Timing of migration............................................ $\quad 70$

Natal Origin Habitat Selection of Pacific-slope flycatchers..................... 76

Precision in carbon and nitrogen analysis............................. $\quad 76$

Physical conditions of Pacific-slope flycatchers............................ 81 
Discussion......................................................... 84

Recommendations for Future Research................................ 92

References........................................................... 95

Appendix A: Example of a field data sheet............................... 113

Appendix B: Weekly Assignment Models................................. 114

Appendix C: Stable isotope values (\%o) of feathers from 167 HY Pacific-slope

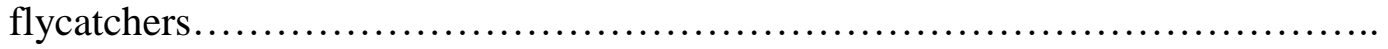




\section{LIST OF TABLES}

Table 1. Average value of $\delta^{2} \mathrm{H}(\%)$ of $169 \mathrm{HY}$ Pacific-slope flycatchers sampled at the Coyote Creek Field Station in Milpitas, California during fall of 2014

Table 2. Bayesian Information Criterion (BIC) for clusters for isotopes from feathers of 167 HY Pacific-slope flycatchers...

Table 3. Bayesian Information Criterion (BIC) for clusters for isotopes from

feathers of 155 HY Pacific-slope flycatchers.......................

Table 4. Mean ( \pm SD) stable isotope ratios of feathers partitioned into 2 clusters based on k-means clustering..............................

Table 5. Canonical Loadings for stable isotope values of feathers from HY Pacific-slope flycatchers

Table 6. Canonical Loadings for morphological measurements of HY Pacific-slope flycatchers 


\section{LIST OF FIGURES}

Figure 1. Growing-season and mean annual global maps for deuterium in precipitation

Figure 2. Location of CCFS within the San Francisco Bay Area, California.....

Figure 3. Study site location adjacent to lower Coyote Creek.

Figure 4. CCFS layout diagramming the four monitoring sites and established mist-net locations

Figure 5. Photo of a hatching-year Pacific-slope flycatcher caught at the Coyote Creek Field Station.

Figure 6. The total number of PSFL caught at CCFS per year from 1995 to 2015 .....

Figure 7. Photos of mist-net collection procedures at CCFS.

Figure 8. Photos of sample preparation procedures

Figure 9. The final "feather isoscape" of predicted hydrogen isotope values of feathers $\left(\delta^{2} \mathrm{H}\right)$ upon which PSFL assignments were made.

Figure 10. Kernal Density estimate of HY PSFL

Figure 11. Probable breeding origins of Pacific-slope flycatchers sampled at the Coyote Creek Field Station in Milpitas, California during fall migration in 2014 . . .

Figure 12. Probable breeding origins of Pacific-slope flycatchers after incorporating North American Breeding Bird Survey Relative Abundance data.

Figure 13. Relationship between $\delta^{2} \mathrm{H}$ and Capture Date of PSFL

Figure 14. Probable breeding origins of Pacific-slope flycatchers sampled from $7 / 20 / 2014$ to $8 / 30 / 2014$.

Figure 15. Probable breeding origins of Pacific-slope flycatchers sampled from $8 / 31 / 2014$ to $10 / 12 / 2014$. 
Figure 16. Timeline of Pacific-slope flycatchers migrating from varying

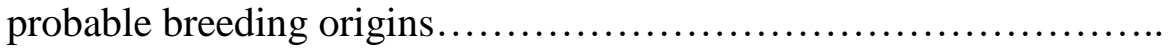

Figure 17. Clustering of stable isotope values of feathers from HY Pacific-slope

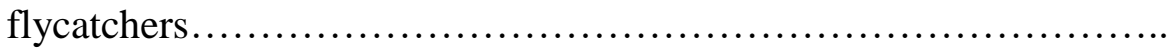

Figure 18. Relationship between loadings (Isotope Values and Morphological Measurements) of HY Pacific-slope flycatchers....................... 


\section{Introduction}

A significant portion of the Earth's biodiversity is threatened by human activities. Scientists suggest that we are in the midst of a mass extinction of biota (hence Anthropocene), estimating that $30-50 \%$ of all known species will be declining towards extinction by 2050 (Thomas et al., 2004). Habitat loss, disease, over-exploitation and competition from invasive species are among the many causes of extinction which are a direct result of human activities including exponential population growth, urbanization and development, pesticide implementation, and predator introduction. Perhaps the greatest threat facing species is changing climate due to human activities, which is expected to contribute substantially to the declines of wildlife populations (Urban, 2015). Bird species, in particular, have shown marked population declines attributed to anthropogenic impacts (Both, Bouwhuis, Lessells, \& Visser, 2006; Both \& Visser, 2001).

The earliest avian extinctions date back to the 1800s when large scavenger bird species disappeared after hunter-gatherers over harvested large herbivores (Martin \& Wright, 1967). The prevalence of avian extinctions only worsened as humans became more industrialized. Examples of just a few avian extinctions include the great auk (Pinguinus impennis) in 1844 to fisherman and collectors (Hume \& Walters, 2013), the passenger pigeon (Ectopistes migratorius) to Industrial Revolution hunters in the $1850 \mathrm{~s}$ (Magoc, 2006), the Labrador duck (Camptorhynchus labradorius) to hunters on Long Island in 1875 (Greenway, 1967), and the ivory billed woodpecker (Campephilus principalis) to a sewing machine company's forest harvest in 1948 (Collar, 1992). There have been at least 11 bird species extinctions in North America (Classic Collection of 
North American Birds, 2016), but, the International Union for Conservation of Nature (IUCN) lists 96 avian species as threatened (IUCN, 2016b) and the 2016 State of the Birds Report stated that 432 North American bird species, more than one-third of all bird species, are in need of immediate conservation action (North American Bird Conservation Initiative, 2016). As of June, 2016, the IUCN Red List stated that 140 avian species were extinct, five were extinct in the wild, 218 were critically endangered, 416 endangered, 741 were vulnerable, and 971 avian species were near threatened worldwide (IUCN, 2016a).

Efforts in the U.S. to protect birds are varied and have deep roots. The first U.S. federal law protecting birds was the Lacey Act of 1900, which prohibited trading illegally obtained wildlife, prevented poaching and shipment of wildlife, and instituted later formed wildlife refuges (American Ornithologists' Union and Cooper Ornithological Society, 2016). In 1913, the Weeks-Mclean Act established federal protection for migratory waterfowl. Following the signing of the Migratory Bird Convention by Great Britain and the U.S. in 1916, a treaty that obliges both countries to protect and preserve migratory birds, the U.S. passed the Migratory Bird Treaty Act in 1918 (U.S. Fish \& Wildlife Service, 2016b). The Migratory Bird Treaty Act continued to separate game birds from non-game birds through additional species classifications, and established a migratory bird list. Under the Migratory Bird Treaty Act, the pursuit, hunting, capturing, taking, killing, or selling of birds within the migratory bird list was prohibited (American Ornithologists' Union and Cooper Ornithological Society, 2016). 
Non-governmental efforts to protect birds have served important roles in supporting protective legislation with notable foundations of organizations such as The American Ornithologists' Union in 1883 (American Ornithologists' Union and Cooper Ornithological Society, 2016) and the Audubon Society in 1905 (Graham, 1990). Such organizations have laid the foundation for country wide efforts by non-profit organizations and researchers to protect birds. Some large-scale present-day efforts include those made by scientists, conservationists, anthropologists and educators involved with National Audubon Society, the Cornell Lab of Ornithology, the American Bird Conservancy, Partners in Flight, the Nature Conservancy, and many more. In the San Francisco Bay Area, non-profit organizations such as the San Francisco Bay Bird Observatory, Point Blue and the Golden Gate Raptor Observatory actively share missions to conserve and protect birds through scientific research, educational outreach, and management recommendations. In addition to, and often in collaboration with non-profit organizations, a large prevalence of academic researchers undertake efforts to protect birds. Many universities, locally and regionally support student and faculty research within a wide range of interdisciplinary scientific programs in which common goals towards improving the protection and conservation of wildlife are shared.

\section{Threats to Migratory Birds}

In North America there are approximately 1,154 native bird species (North American Bird Conservation Initiative, 2016) of which 386 are considered Neotropical migrants, birds that breed in the U.S. or Canada during the summer and spend the winter in Mexico, Central America, the Caribbean, or South America (U.S. Fish \& Wildlife 
Service, 2016a). Of North America's Neotropical migratory birds, 185 are Passeriformes, perching songbird species (U.S. Fish \& Wildlife Service, 2016a). Each year many Neotropical migrant songbirds travel along the Pacific Flyway, the western most migratory route in North America.

The natural phenomenon of migration, defined as the yearly seasonal movement of individual birds originating from a specific breeding location to a specific wintering location and back again, is what allows populations of birds to move in between areas of varying abundances of resources in search for optimal food and nesting availability (Webster, Marra, Haig, Bensch, \& Holmes, 2002). In North America, birds migrate twice a year. A typical pattern is that birds migrate in the fall going from summer nesting habitats to southern wintering regions, then back in the spring. Birds in North America spend approximately two to three months on their northern breeding grounds and two to three months migrating to and from their southern wintering grounds where they spend six to seven months (Norris, Marra, Kyser, Sherry, \& Ratcliffe, 2004). Birds may migrate relatively short distances, such as the northern bobwhite (Colinus virginianus), which only migrates to different elevations to winter or breed within the same mountain range (Brennan, Hernandez, \& Williford, 1999), or extremely long distances such as the sooty shearwater (Puffinus griseus), which migrates 40,000 miles a year between breeding ranges in the North Pacific Ocean and wintering sites in New Zealand (Shaffer et al., 2006). Species have evolved to migrate primarily for food and better habitats, although competition and reproduction opportunities may be other factors (Zink, 2011). Several studies have investigated the implications of food limitations, climatic stressors, and 
breeding threats on birds (Bell, 2005; Berthold, 2001; Cox, 1985) and found that migration is best described as a strategy employed to seasonally abandon inadequate resource areas, promote survival and reproduction by avoiding extreme climates, and dodge locations with numerous predators - all with the goal of promoting successful nesting and reproduction in the following year (Boyle \& Conway, 2007).

As birds prepare to migrate, they often face challenging environmental conditions as resources decline on their summer nesting grounds; migratory challenges are magnified by the taxing experience of flight travel during which migratory birds are constantly on the move to inhabit a variety of locations. Some of the most daunting challenges within the migration time frame that birds face are- time sensitivity of body mass storage requirements, mental pressures associated with proper navigation and unfamiliar habitats, limited stopover resources, physical land barriers, climatic fluctuations, competition, predators, and energy use (Carlisle et al., 2009; Klaassen, 1996).

The quality of stopover environments is critical for survival as birds rely heavily on these sites to rest and replenish fuel supplies (Buler \& Moore, 2011; Moore, Smith, \& Sandberg, 2005). For fall or spring migrations to be successful, birds must arrive at the wintering grounds (to claim a territory) or the breeding grounds (to claim a nest site and secure a mate) in a timely manner, so time spent foraging at stopover sites must be optimized (Moore et al., 2005). When birds arrive during stopovers, energy levels are typically low and the duration spent at the stopover site is dependent upon food availability, ability to locate resources, ability to avoid stress, predator abundance, weather, competition, sex, and age (Åkesson \& Hedenström, 2000; Cohen, Moore, \& 
Fischer, 2014; Goymann, Spina, Ferri, Fusani, \& Fusanu, 2010; Moore \& Aborn, 2000; Schaub, Jenni, \& Bairlein, 2008; Yong \& Moore, 1997).

Anthropogenic impacts can affect breeding, wintering and stopover habitats thereby negatively affecting migratory birds. Habitat quality is degraded or eliminated by urbanization, agricultural developments, water and energy management systems, the impact of global climate change, spread of disease, and domestic and introduced predators (Carlisle et al., 2009; Holmes, 2007; Kelly, Finch, \& Yong, 2000; Kuvlesky et al., 2007; Mehlman et al., 2005).

The variety and intensity of annual stressors can subject migratory birds to higher mortality rates than resident bird species (Carlisle et al., 2009; Møller, Rubolini, \& Lehikoinen, 2008). Some studies have found alarmingly high rates of mortality during migratory periods for some species like black-throated blue warblers (Dendroica caerulescens) (Sillett \& Holmes, 2002), pied flycatchers (Ficedula hypoleuca) (Both et al., 2006), southwestern willow flycatchers (Empidonax traillii extimus) (Paxton, 2008), and wood thrushes (Hylocichla mustelina) (Rushing, Ryder, Marra, \& Rushing, 2016).

Some of the most sensitive species are Neotropical migrant songbirds; these birds are primarily insectivores, breed in North America and winter in the tropics when insect abundances vary in temperate zones. Avian monitoring programs such as the Breeding Bird Survey (BBS), Christmas Bird Count (CBC) and Monitoring Avian Productivity and Survivorship (MAPS) have been implementing methodical, continent-wide surveys since the 1960s. These programs show a large portion of the bird species in decline are Neotropical migrants. BBS data (from 1966 to 2006) has shown that 57\% of all 
Neotropical migrant songbird populations in North America are declining (BirdLife International, 2008; Sauer, Hines, \& Fallon, 2007). Quantification of avian mortality during migration is essential to conservation strategies (Carlisle et al., 2009).

Understanding the migratory pathways of birds is essential for species conservation and management, but collecting these data has been extremely difficult. There are a variety of methodologies that have been applied in avian migration studies such as mark and recapture, citizen science, telemetry, and tissue analyses. Mark and recapture allows researchers to track the movements and survival of birds through marking individuals with unique tags. The strength of this methodology is limited as it requires re-sighting of the tags or recapturing of birds by relying on chance alone. Citizen science data has supported mark and recapture studies through annual bird counting programs and provides valuable records of population trends at given locations and times throughout the year, but lacks information on individual birds, which hinders abilities to infer connections between migratory populations of concern. Advanced telemetry technology such as radio, satellite and GPS transmitters attach to individual birds and collect reliable movement data, but can be very expensive and often require recapture for device removal. The analysis of bird tissues such as feathers, claws or blood can provide genetic or biogeochemical information about the location in which the specific tissue was grown in allowing for geographic inferences of migrating populations of individuals. Tissue analyses are relatively inexpensive and do not require recapture, but are very sensitive to environmental influences increasing sources of error. 


\section{Pacific-slope flycatchers (Empidonax difficilis)}

Pacific-slope flycatchers (PSFL) are small, insectivorous, Neotropical migrant songbirds. In 1989 the American Ornithologists' Union replaced the previous western flycatcher (Empidonax difficilis) North American bird account with two separate listings; the Pacific-slope flycatcher(Empidonax difficilis) and the cordilleran flycatcher (Empidonax occidentalis) (Monroe et al., 1989). Due to significant geographic differences in the distribution of Pacific-slope and cordilleran flycatchers, this study solely addresses Pacific-slope flycatchers.

The Pacific-slope flycatcher breeds in coastal habitats consisting of humid coniferous forest, pine-oak forest, and dense second-growth woodland and winters in tropical habitats consisting of montane evergreen forest, gallery forest, tropical deciduous forest, and tropical lowland evergreen forest (American Ornithologists' Union, 1998; Lowther, 2000). The breeding range stretches from southeastern Alaska, northwestern and central British Columbia, and the Queen Charlotte and Vancouver islands to southwestern California and throughout the mountain ranges of northern and southern Baja California (American Ornithologists' Union, 1998; Lowther, 2000).

In California, the PSFL has mostly been found to breed west of the Cascade and Sierra Nevada Mountain Ranges (American Ornithologists' Union, 1998; Lowther, 2000). The winter range includes southern Baja California and spans from northwestern Mexico to Oaxaca (American Ornithologists' Union, 1998). Known spring and fall migration stopover sites of the PSFL have been summarized by Lowther (2000). Spring stopover sites include Colorado River, AZ; San Diego County, Orange County, Santa 
Barbara County, Monterey County, and Humboldt County, CA; East of Cascades and Lincoln County, Oregon; Coastal and Queen Charlotte Islands, British Columbia; Ketchikan, Alaska from late February to late June depending on the location (Lowther, 2000). Fall stopover sites include Juneau, Alaska; Vancouver, British Columbia; Lincoln County, Oregon; Santa Clara, Monterey County, Santa Barbara County, and San Diego County, CA; and Colorado River, AZ from late July to early November depending on the location (Lowther, 2000).

The current conservation status of PSFL determined by the IUCN is of Least Concern, although population trends show decreasing populations (BirdLife International, 2012). Breeding Bird Survey data indicate PSFL populations fluctuated insignificantly between the $1960 \mathrm{~s}$ and the late $1990 \mathrm{~s}$, but have been decreasing in the $21^{\text {st }}$ century (Sauer et al., 2007). Combined BBS and Christmas Bird Count data have also shown small decreases in the Pacific-slope and cordilleran flycatcher populations (Butcher \& Niven, 2007). Although current PSFL populations are relatively large and viable, the causes of these population declines are poorly understood (BirdLife International, 2012). There is a dearth of information about the major threats to Pacificslope flycatchers. Previous studies conducted in Douglas-fir (Pseudotsuga menziesii) habitats (Raphael, Rosenberg, \& Marcot, 1988; Rosenberg, Ohmart, Hunter, \& Anderson, 1991) have found that PSFL tend to avoid human created clear-cut edges and prefer old growth forests for optimal insect feeding. During secondary succession, Douglas-fir forests of northwestern California, researchers estimated a 39\% population decline between 1980 and 1984 (Raphael et al., 1988). More information on the threats to 
Pacific-slope flycatcher populations is needed to fully evaluate the viability of this species.

Properly tracking the status of these populations remains problematic for wildlife managers, especially within the interior Pacific Northwest (Lowther, 2000). Little to no information exists on the assessment of migratory connectivity in these populations. Hence, the purpose of the present study is to characterize the migratory connectivity of Pacific-slope flycatchers that migrate south through the San Francisco Bay region each fall, en route to destinations further south. This study contributes to aspect limited body of knowledge regarding the migratory connectivity of PSFL by focusing solely on the natal (also presumed breeding) origins of migratory hatching-year (HY) flycatchers.

My approach used an indirect method of migratory connectivity by using stable isotope analysis (SIA) of Pacific-slope flycatcher tail feathers to estimate provenance and prior habitat exposure. I also examined whether there were relationships between flycatcher morphological characteristics and relative breeding origins. This is the first migratory connectivity study which addresses the annual cycle of Pacific-slope flycatchers. The results of this study provide essential information for population ecologists to make connections between Pacific-slope flycatcher breeding origins, stopover sites, and wintering grounds; further quantifying the dynamics of the PSFL annual cycle. This research also provides spatial and temporal timelines for wildlife managers to implement conservation measures at known breeding and stopover sites. Finally, the methods used in this research can serve as a model for studies investigating the migratory connectivity of other Neotropical bird species. 


\section{Related Research}

\section{Migratory Connectivity}

The study of avian migration and subsequent population trends involves the concept of migratory connectivity, a way of evaluating the similarities in movements of populations of birds by recognizing links between individuals in breeding, stopover and wintering areas (Marra, Hobson, \& Holmes, 1998; Webster et al., 2002). Common but vital information in avian conservation is to understand how often groups of birds from a certain breeding location move together to the same wintering location each winter, rather than disperse to a variety of wintering locations (Esler, 2000; Webster et al., 2002). Migratory connectivity measures population connections between travel routes and stopover sites and across multiple events during a year (Boulet, Gibbs, \& Hobson, 2006; Webster et al., 2002). The survival rate of an individual migratory bird or of its population can depend on certain events that occur throughout a yearly cycle, with the notion that the impact of one seasonal event may not be reflected until the following season, hence carry-over effects (Chamberlain et al., 1997; Fretwell, 1972).

Migratory connectivity is described as a level of strength; stronger connectivity denotes a population with groups of migrants from certain locations, whether breeding or wintering, who collectively migrate to the same area and back (Marra, Norris, Haig, Webster, \& Royle, 2006). Conversely, weak connectivity is when a group of migrants disperse to a variety of locations (Marra et al., 2006). The strength of a population's connectivity has direct implications for breeding viability, evolution, genetic variation, 
disease control, and habitat availability, with weaker connectivity being more desirable (Both et al., 2006; Boulet et al., 2006; Webster et al., 2002).

Many studies focusing on migratory connectivity demonstrate links between breeding and wintering grounds, and disregard the potential influence that the physical act of migration and stopover may have on populations of birds (Moore et al., 2005; Newton, 2004; Paxton \& Moore, 2015; Sillett \& Holmes, 2002). The challenges of migration pose significant threats to migratory birds, and links between breeding and wintering grounds should be made with the incorporation of birds that did not survive their migratory route (Paxton \& Moore, 2015). The relationship between migratory birds and their stopover habitats is essential for understanding the connection between breeding and wintering grounds, and can further quantify migration success (Yong \& Moore, 1997). To fully understand migratory connectivity, the identification of stopover sites during migration is an essential step for protecting avian populations (Cohen et al., 2015; Hobson et al., 2006; Mazerolle, Hobson, \& Wassenaar, 2005; Newton, 2004; Ruegg et al., 2014; Webster \& Marra, 2005; Webster et al., 2002). Conservation of Neotropical migrant songbirds requires protection and management of all habitats that are used by populations throughout their annual cycle (DeGraaf \& Rappole, 1995; González-Prieto, Hobson, Bayly, \& Gómez, 2011; Moore, Kerlinger, \& Simons, 1990; Morris, Holmes, \& Richmond, 1996).

\section{Research Methods}

Researchers have used a number of techniques to quantify the migratory connectivity of an individual group or population. One of the most historic, prominent, and direct 
methods of studying bird migration is mark and recapture using bird banding, in which the movement, survival, and behavior of birds is evaluated by marking an individual with a unique band or tag. Specific morphological characteristics are then assessed to differentiate between different species and origins (U.S. Department of the Interior \& U.S. Geological Survey, 2016). One of the most important components of mark and recapture studies is the ability of researchers to recapture and/or re-sight previously marked birds (Webster et al., 2002). With the help of citizen science programs such as The Christmas Bird Count, The North American Breeding Bird Survey, The Great Backyard Bird Count and Grassland Bird Surveys, many mark and recapture studies are made possible. Although mark and recapture methods are widely used, the approach is not ideal for studying specific movements of migratory birds primarily because the odds of recapturing and re-sighting previously marked birds are very small, which reduces the ability to make reliable conclusions about a population's migratory patterns (Webster et al., 2002). Additionally, mark and recapture data are not always adequate for applying statistical analyses to measure migratory connectivity (Webster et al., 2002). And, the lack of observer confidence associated with re-sighting methods may falsify conclusions on a birds' breeding or wintering origins.

Newer technologies have provided many opportunities for researchers to acquire a clearer understanding of avian migration paths. Radio telemetry, satellite telemetry, geolocators, GPS transmitters and a variety of other technological tools allow for the closer, sometimes instantaneous, tracking of individual movements, while collecting information on the external environment (Hobson \& Norris, 2008; Webster et al., 2002). 
By attaching a tracking device, researchers can obtain relatively accurate data on the activity throughout an annual cycle, which can answer many important questions about avian migration and life history patterns. Although the benefits of telemetry are significant, the costs and limitations associated with species size make the option a less desirable one for widespread use in migration studies (Webster et al., 2002).

Nevertheless, intrinsic markers, naturally occurring elements in food resources that are incorporated into animal tissues during physiological processes, can be used to evaluate breeding and wintering origins of birds (Boulet et al., 2006). By sampling tissue specimens from a migratory bird, genetic and biogeochemical analyses can be used to estimate the origin of tissue growth at the time of synthesis (Boulet et al., 2006). The analyses of contaminants, parasites, pathogens, trace elements, mitochondrial DNA, genome sequences, and stable isotopes are some of the intrinsic approaches that have been used to infer migratory movements of wildlife (Hobson \& Norris, 2008; Ruegg et al., 2014). The analysis of mitochondrial DNA and stable isotopes are two of the preferred approaches being applied in many migratory connectivity studies (Boulet et al., 2006; Hobson \& Norris, 2008; Paxton, Van Riper III, Theimer, \& Paxton, 2007; Ruegg et al., 2014; Rundel et al., 2013; Sullins et al., 2016; Webster et al., 2002; Woodworth et al., 2016).

A stable isotope is a natural deviation in the weight of a chemical element based on neutron abundance variation (Inger \& Bearhop, 2008). Elements such as hydrogen (H), oxygen $(\mathrm{O})$, carbon $(\mathrm{C})$, nitrogen $(\mathrm{N})$, strontium $(\mathrm{Sr})$ and sulphur $(\mathrm{S})$ all appear in different forms in the environment as stable isotopes and are uniquely identified based on 
their atomic weights (Fry, 2006; Inger \& Bearhop, 2008; Wassenaar, 2008; Webster et al., 2002). Ratios of stable isotopes in nature have been shown to reflect a variety of patterns across different habitats and landscapes (i.e. an isoscape), with elevation levels, among food web systems and consequently geographically (Hobson, 2009; Inger \& Bearhop, 2008; Wassenaar, 2008; Webster et al., 2002). The ratios of stable isotopes in the environment are reflected in the tissues of animals grown in at a given location, allowing researchers to analyze the tissues for information on trophic placement and relative origin of tissue growth (Bearhop, Furness, Hilton, Votier, \& Waldron, 2003; Haramis, Jorde, Macko, Walker, \& Walker, 2001; Hobson, 2009; Inger \& Bearhop, 2008; Pearson, Levey, Greenberg, \& Martínez Del Rio, 2003; Webster et al., 2002).

When birds are at a particular point in their molt cycle and grow in their feathers at their breeding, stopover, or wintering grounds, the environmental isotopic signatures becomes incorporated into their external tissues due to the inert properties of feather proteins (Inger \& Bearhop, 2008). Essentially, feathers serve as isotopic signature records, and this naturally occurring process provides a proxy for researchers to estimate species diet (i.e. trophic placement) and geospatial origin in relation to an isoscape map (Inger \& Bearhop, 2008).

The analysis of hydrogen isotope ratios in avian tissues has been used widely to infer relative geographic origins (Hobson \& Norris, 2008; Inger \& Bearhop, 2008). Deuterium, $\left(\delta^{2} \mathrm{H}\right)$, the heavier of the two stable hydrogen isotopes, varies continent-wide through precipitation, and up taken into animal tissues (Hobson \& Norris, 2008; Inger \& Bearhop, 2008). Many early studies (Hobson \& Wassenaar, 1997; Hobson, Wassenaar, \& Taylor, 
1999; Holmes et al., 1997; Kelly, Atudorei, Sharp, \& Finch, 2002; Meehan, Giermakowski, \& Cryan, 2004; Rubenstein et al., 2002) correlated deuterium in bird feathers with average deuterium values of precipitation across North America (Inger \& Bearhop, 2008). Deuterium values in water have been found to occur on a geographic sliding scale basis with latitude changes; deuterium values will decrease as latitude increases (Hobson \& Wassenaar, 1997; Inger \& Bearhop, 2008; Marshall, Brooks, \& Lajtha, 2007). Deuterium values will also decrease at higher elevations (altitude), with increased distances from the ocean (continental effect), and in areas with more rainfall (rainfall amount effect) (Kendall, Sklash, \& Bullen, 1995; Marshall et al., 2007; Plummer, Michel, Thurman, \& Glynn, 1993). Deuterium undergoes isotopic discrimination while it passes through food chains during natural processes such as evaporation, condensation, plant absorption, and trophic consumption (Wassenaar, 2008). The consistency of isotopic discrimination is predictable of latitude, allowing a basis for comparison with deuterium values in the feathers of birds (Hobson \& Wassenaar, 1997; Wassenaar, 2008).

The creation of continental maps showing deuterium precipitation value (i.e. isoscape map) changes with latitude by Bowen, Wassenaar, \& Hobson (2005) (Figure 1) has allowed researchers to analyze the deuterium values in animal tissues as an intrinsic marker of origin (Inger \& Bearhop, 2008). 


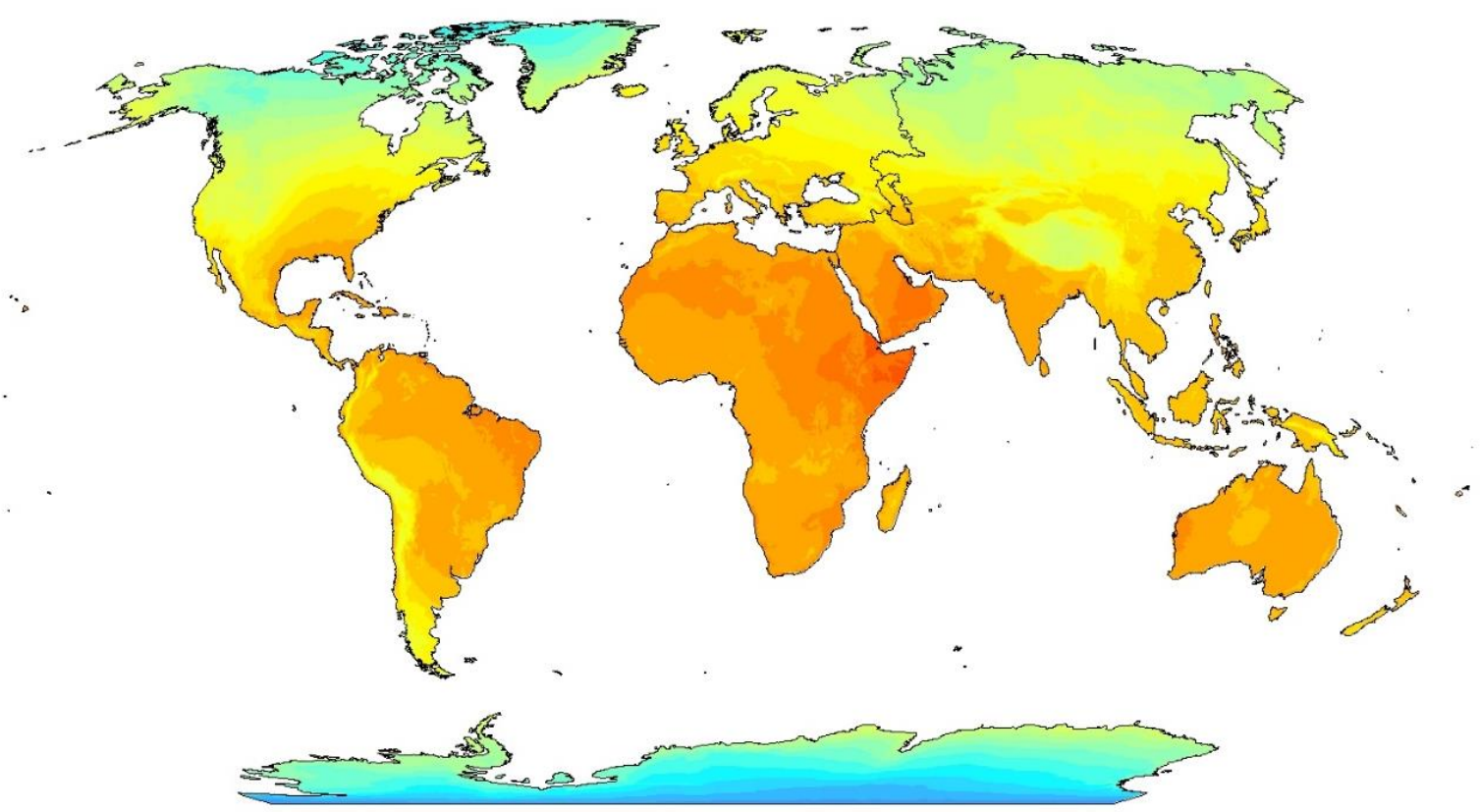

$\delta^{2} \mathrm{H}$ of Annual Precipitation

Figure 1. Growing-season and mean annual global maps for deuterium in precipitation, reprinted with permission from Bowen et al. (2005)

The analysis of carbon and nitrogen stable isotope ratios in avian tissues has been used to study diet selection, foraging history, trophic ecology, and habitat use (Bearhop et al., 2003; Inger \& Bearhop, 2008; Kelly, 2000; Lajtha \& Marshall, 1994; Peterson \& Fry, 1987). The heavy carbon stable isotope, $\left(\delta^{13} \mathrm{C}\right)$, varies based on the type of photosynthesis a plant undergoes (Inger \& Bearhop, 2008; Marshall et al., 2007). Terrestrial plants can be categorized based on the type of photosynthetic pathway (e.g., $\mathrm{C}_{3}, \mathrm{C}_{4}$, and CAM plants), are distributed geographically based on climatic conditions and subsequently use different processes to uptake $\mathrm{CO}_{2}$, which causes a variation in the heavy 
carbon isotope signatures (Marshall et al., 2007). $\mathrm{C}_{3}$ plants are typically found in temperate habitats with cooler, wetter climates and undergo higher fractionation of carbon isotopes resulting in less enriched (more negative) $\delta^{13} \mathrm{C}$ values than $\mathrm{C}_{4}$ plants which can be found in semi-tropical habitats with hotter, drier climates such as grasslands or savannas (Still, Berry, Collatz, \& DeFries, 2003; Still \& Powell, 2010; Waller \& Lewis, 1979).

Heavy nitrogen stable isotope $\left(\delta^{15} \mathrm{~N}\right)$ values will vary based on diet and trophic level; tissues of consumers that rely on high protein diets are more enriched in $\delta^{15} \mathrm{~N}$ than lower individuals in the food chain (Inger \& Bearhop, 2008). Heavy nitrogen stable isotope values can also be influenced by environmental soil content, such as in regions with high agricultural activity (Inger \& Bearhop, 2008). Bird feathers reflect levels of $\delta^{15} \mathrm{~N}$ variation based on diets with higher protein sources such as strict insectivores (higher $\delta^{15} \mathrm{~N}$ values), omnivorous diets consisting of insects and plants (low $\delta^{13} \mathrm{C}$ to $\delta^{15} \mathrm{~N}$ ratios) or diets consisting of fruits (high $\delta^{13} \mathrm{C}$ to $\delta^{15} \mathrm{~N}$ ratios) (Hobson, 2009).

Similar to deuterium, plant $\delta^{13} \mathrm{C}$ values undergo isotopic discrimination when consumed and digested by wildlife, and animal tissues will become more enriched with $\delta^{15} \mathrm{~N}$ values as they move through trophic levels (Inger \& Bearhop, 2008; Post, 2002). The shift in stable carbon and nitrogen isotope ratios during these processes provide a predictable basis for inferring diet composition and trophic level of consumers (Inger \& Bearhop, 2008; Kelly, 2000). Many studies (Bearhop et al., 2003; Evans, Newton, Mallord, \& Markman, 2012; Gagnon \& Hobson, 2009; Haramis et al., 2001; Hobson, 1999a; Hopkins \& Ferguson, 2012; Pearson et al., 2003) have analyzed the $\delta^{13} \mathrm{C}$ and $\delta^{15} \mathrm{~N}$ 
values in the tissues of birds to infer variation in diet among different habitat types and to investigate trophic relationships. It has been observed that the analysis of all three isotopes $\left(\delta^{2} \mathrm{H}, \delta^{13} \mathrm{C}\right.$, and $\left.\delta^{15} \mathrm{~N}\right)$ can yield important information about the origins and habitat variation of migratory birds (Garcia-Perez \& Hobson, 2014; Hobson et al., 2012; Hobson, Van Wilgenburg, Wassenaar, Moore, \& Farrington, 2007; Reudink et al., 2015). For example, Garcia-Perez \& Hobson (2014) analyzed multiple isotopes in barn swallows (Hirundo rustica) while on their breeding grounds and were able to estimate wintering origins. Similarly, Reudink et al. (2015) applied multi-isotope methodologies to a sample of Vaux's swift (Chaetura vauxi) at a migratory stopover site and found natural distinct groups from different wintering origins. Hobson et al. (2012) found latitudinal trends in plant $\delta^{13} \mathrm{C}$ and $\delta^{15} \mathrm{~N}$ values across Africa, allowing for successful migratory assignments of previous published feather data.

Morphological characteristics of birds have been widely studied to better understand migratory energetic abilities, foraging behavior, and mechanisms of adaptation (Hedenström, 2008; Milá, Wayne, \& Smith, 2008; Nowakowski, Szulc, \& Remisiewicz, 2014; Pérez-Tris \& Tellería, 2003; Shaffer, Weimerskirch, \& Costa, 2001; Vágási et al., 2016). Certain morphological variables such as wing length, fat score, body mass and size have been examined closely in migration studies. It has been observed that some birds who migrate longer distances have longer wings (Maggini, Spina, Voigt, Ferri, \& Bairlein, 2013; Milá et al., 2008; Nowakowski et al., 2014; Pérez-Tris \& Tellería, 2003; Vágási et al., 2016) and lower body masses (Jones \& Witt, 2014; Kaboli, Aliabadian, Guillaumet, Roselaar, \& Prodon, 2007; Moore et al., 2005). Fat score is a visual indicator 
of total body fat and has been found to be higher in birds that are foraging for several days at a migratory stopover site (Lindström, Klaassen, Piersma, Holmgren, \& Wennerberg, 2002; Meissner, 1996; Meissner, 2009; Wichmann, Barker, Zuna-Kratky, Donnerbaum, \& Rössler, 2004). There have been few studies that have investigated the potential relationships between the morphological measurements and stable feather istopes of migrating songbirds, and in those that have focus questions within topics on foraging selection (Arizaga, Alonso, \& Hobson, 2014; Møller \& Hobson, 2004), nutritional stress (Kempster et al., 2007) phenomics (Bensch, Grahn, Müller, Gay, \& Åkesson, 2009) and migratory connectivity (Delingat, Hobson, Dierschke, Schmaljohann, \& Bairlein, 2011) Arizaga, Alonso, \& Hobson’s (2014) study investigated the foraging selection of crossbills (Loxia spp.) by collecting a suite of morphological measurements and $\delta^{2} \mathrm{H}$ feather isotope values and were able to make differentiating conclusions about a migratory population utilizing a stopover site. A study by Delingat et al. (2011) found significant differences in wintering origins of groups of northern wheatears (Oenanthe oenanthe) based on wing shape, wing size and $\delta^{2} \mathrm{H}, \delta^{13} \mathrm{C}, \delta^{15} \mathrm{~N}$ feather values of birds at breeding and stopover sites on offshore islands of Germany.

Aside from research by (Delingat et al., 2011) little to no information exists about the integration of morphological measurement assesment with stable isotope analysis within migratory connectivity studies.

\section{Pacific-slope flycatchers (Empidonax difficilis)}

There is a dearth of information about the migratory connectivity of Pacific-slope flycatcher populations. The American Ornithologists' Union's 1989 decision to officially 
split the western flycatcher (Empidonax difficilis) into two species, the Pacific-slope flycatcher (PSFL) and the cordilleran flycatcher (Empidonax occidentalis), was made after research by (Johnson \& Marten, 1988) found there to be enough significant vocal, genetic and slight morphological differences in inland and coastal populations of the western flycatcher to consider the separate populations to be unique species (Johnson \& Marten, 1988; Monroe et al., 1989). Alternatively, morphometric identification criteria only allows for distinction of $60 \%$ of individuals (Pyle, Institute for Bird Populations, \& Point Reyes Bird Observatory, 1997). A study of Pacific-slope and cordilleran flycatcher DNA by (Rush, Cannings, \& Irwin, 2009) revealed hybridization between the two species in southeastern British Columbia and southwestern Alberta, providing possible evidence for the need for population re-merge. Some organizations and databases such as the Cornell Lab of Ornithology's Birds of North America Online, the North American Breeding Bird Survey, and the San Francisco Bay Bird Observatory continue to refer to the former nomenclature of western flycatcher to address both species simultaneously. The decision to split the western flycatcher into two species has restricted our understanding of the annual cycles of these populations as unique species.

Previous research on the migration of Pacific-slope flycatchers has focused on topics that address population abundance, foraging selection, and local movements. Certain trends in the abundances of PSFL populations have been observed to be influenced by geographic location and habitat. In a study conducted at the Rocky Point Bird Observatory in Vancouver Island, British Columbia from 1997- 2003 by Christie (2004), Pacific-slope flycatchers showed a significant increase in abundance potentially related to 
a preference for the coastal interior forest habitats of Vancouver Island. Similarly, Skagen et al. (2005) found PSFL abundances to increase with increasing longitude (closer to the coast) at migratory stopover sites throughout the southern U.S. and Mexico. Research has shown that migratory PSFL favor areas with certain vegetation to support stopover foraging of insects, such as the finding of PSFL reliance on flowering honey mesquite (Prosopis glandulosa) by (Fontaine \& Van Riper III, 2009) at the Cibola National Wildlife Refuge in Arizona.

Although previous research sheds light on important factors that influence Pacificslope flycatcher population abundances and migratory habitat selection, assessment of migratory connectivity has never been addressed. Aside from a study by (Nocedal, 1994) which examined short distance movements between habitats in western Mexico, research on the migratory timing and movement of Pacific-slope flycatcher populations in relation to breeding, stopover and wintering grounds does not exist. 


\section{Objectives}

With the growing variety of external stressors and the increasing sensitivities of Neotropical migrant songbirds, the mortality rates of migratory birds are rising. The direct causes of declines are poorly understood, and a major knowledge gap is our understanding of the relationship between Neotropical migrant songbirds' breeding and wintering habitat and the migratory routes birds take. Mortality factors cannot be adequately quantified without narrower resolutions of breeding origins, stopover points, and wintering grounds for individual species of interest. Little to no information exists on links between particular breeding, stopover and wintering areas of Neotropical migrant songbirds (Hobson \& Wassenaar, 1997), and without filling in these gaps, the roadblocks preventing proper conservation strategies will remain unresolved.

The overall objective of this study was to contribute to the assessment of migratory connectivity in Pacific-slope flycatchers. My goal focused on evaluating the breeding origins and variation in breeding habitat exposure of HY Pacific-slope flycatchers migrating through the Coyote Creek Field Station in Milpitas, CA at different times during the fall 2014 migration season. This study also examined relationships between the morphological characteristics of HY Pacific-slope flycatchers and the inferred relative breeding origins and habitat exposure.

This research provides the necessary data to better define HY PSFL fall migratory routes, serves as a resource for wildlife managers to further protect known stopover habitats, and may be used as a model for other ecologists conducting similar migratory 
connectivity studies. The following research questions and hypotheses address the objectives of this study.

\section{Research Questions}

Q1: Based on $\delta^{2} \mathrm{H}$ signatures, what are the probable breeding origins of the entire PSFL sample that migrated through CCFS in fall of 2014 ?

Q2: Does the incorporation of temporal data improve our ability to determine the probable breeding origins of Pacific-slope flycatchers that migrated through CCFS in fall of $2014 ?$

Q3: Based on $\delta^{2} \mathrm{H}, \delta^{13} \mathrm{C}$ and $\delta^{15} \mathrm{~N}$ signatures, are there differences in the ecological niches of the natal habitats that the PSFL occupied prior to migrating through CCFS in the fall of 2014 ?

Q4: Are there relationships between morphological measurements and feather isotope values of the Pacific-slope flycatchers that migrated through CCFS in the fall of 2014 ? $\left(\mathrm{H}_{0} 1\right)$

\section{Null Hypotheses}

$\mathrm{Ho}_{1}$ : There will be no relationships between the morphological measurements and the feather isotope values of the Pacific-slope flycatchers sampled at the Coyote Creek Field Station in the fall of 2014. 


\section{Methods}

\section{Study Site}

The Coyote Creek Field Station (CCFS) is located within a parcel of mixed riparian forest and woodland at the southernmost portion of the San Francisco Bay in Milpitas, California (Figure 2).

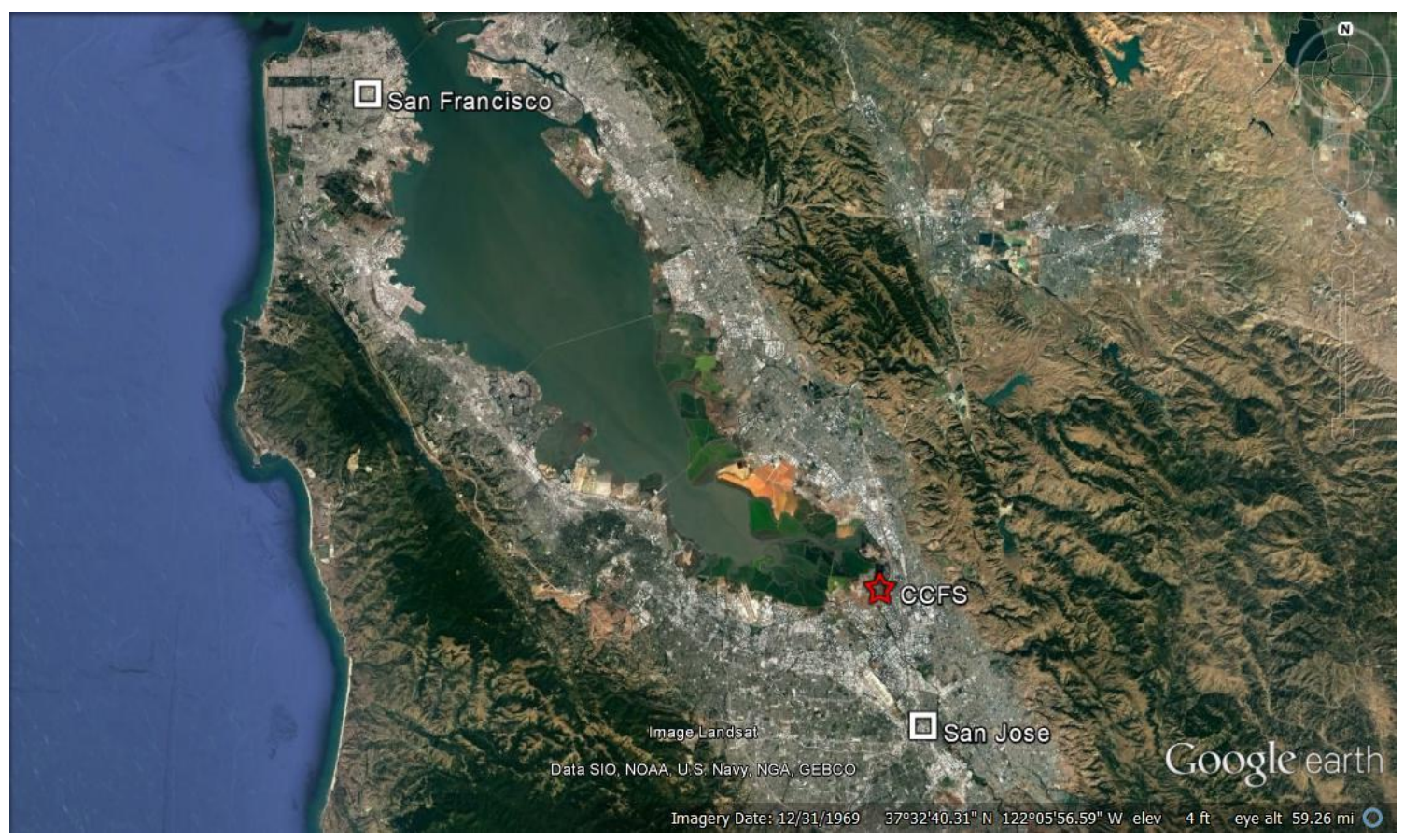

Figure 2. Location of CCFS within the San Francisco Bay Area, California (Google Earth, 2016).

CCFS lies within California's Santa Clara Valley approximately $73 \mathrm{~km}$ south east of San Francisco, $13.7 \mathrm{~km}$ north east of San José, and $5.6 \mathrm{~km}$ east of Alviso, 37²6'17.03"N $121^{\circ} 55^{\prime} 42.54^{\prime \prime W}$. The site is situated adjacent to lower Coyote Creek (Figure 3), and is part of the Coyote Creek watershed (Jaramillo, Hudson, \& Strong, 1996). 


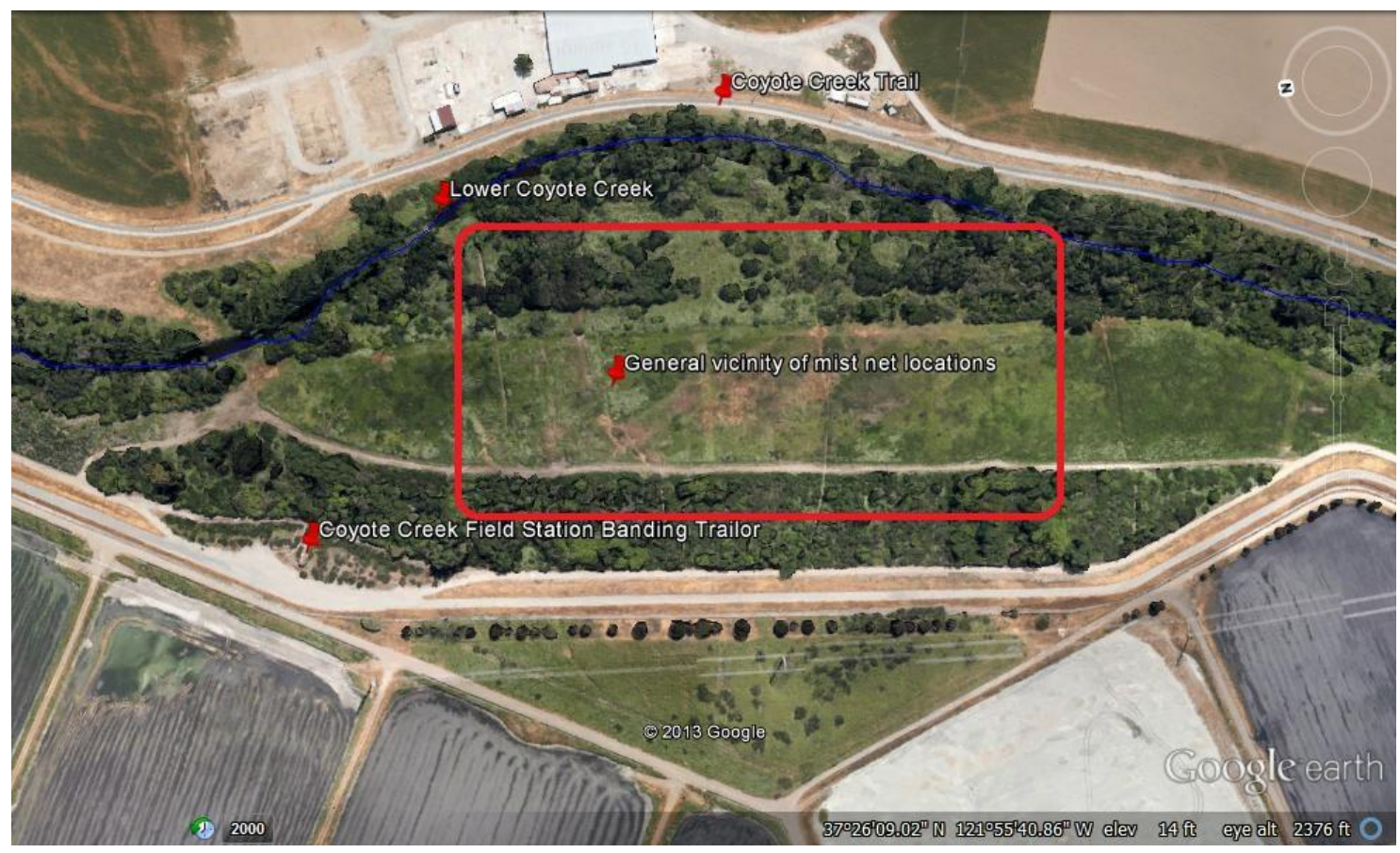

Figure 3. Study site location adjacent to lower Coyote Creek (Google Earth, 2016).

The site was originally operated by the Santa Clara Valley Water District (SCVWD) from 1987 to 1993 when a series of flood prevention operations and subsequent habitat restoration occurred (Jaramillo et al., 1996; Rigney, Mewaldt, Wolf, \& Duke, 1989). The non-profit scientific organization, The San Francisco Bay Bird Observatory (SFBBO), assisted the SCVWD by monitoring wildlife on site. In 1999, in collaboration with another non-profit research organization, the Coyote Creek Riparian Station, SFBBO acquired CCFS as part of the Bird Observatory's Landbird Program. SFBBO continues bird banding operations at CCFS under the North American Bird Banding Program administered by the United States Geological Survey and the Department of the Interior.

Santa Clara County experiences a Mediterranean climate in which the warmest and driest conditions occur between the spring and summer months of April and October, and cooler, wetter conditions occur during the fall and winter, from November to March. 
Year round average temperatures can range from lows of $3.3^{\circ} \mathrm{C}$ to highs of $31.6^{\circ} \mathrm{C}$. The average rainfall of Milpitas is 37.8 centimeters with the majority of the rain occurring in January and February (National Oceanic and Atmospheric Administration, 2016). The elevation at CCFS is six to nine meters above sea level.

Historically, the area surrounding CCFS included riparian vegetation bordering riverbeds to oak stands dominating grasslands near shorelines and a widespread variety of willow species (Jaramillo et al., 1996). Riparian trees at CCFS include western sycamore (Platanus racemosa), Fremont cottonwood (Populus fremontii), willow (Salix lucidum, S. laevigata, S. lasilopis, and S. exigua), and oak (Quercus lobata and Q. agrifolia) (Jaramillo et al., 1996). Although the riparian forest around CCFS has remained relatively undisturbed, the urban development has greatly reduced the riparian corridor in size and has eliminated the native oak woodland. Flood prevention operations such as the on-site construction of the overflow channel, the waterway created by plowing portions of the existing vegetation in 1989-1990, construction and development of Highway 237, and the growth of surrounding businesses, parks and shopping malls (Jaramillo et al., 1996) have all contributed to the disturbance of the surrounding CCFS ecosystem.

As mitigation for a major flood-control project conducted by the SCVWD from 19871993, CCFS implemented a series of on-site riparian habitat restoration and monitoring projects (Jaramillo et al., 1996; Rigney et al., 1989). Four monitoring sites within the area were identified: 1) the Riparian site, 2) the Pilot Revegetation site, 3) the Overflow Channel, and 4) the New Revegetation site (Figure 4) (Jaramillo et al., 1996). 


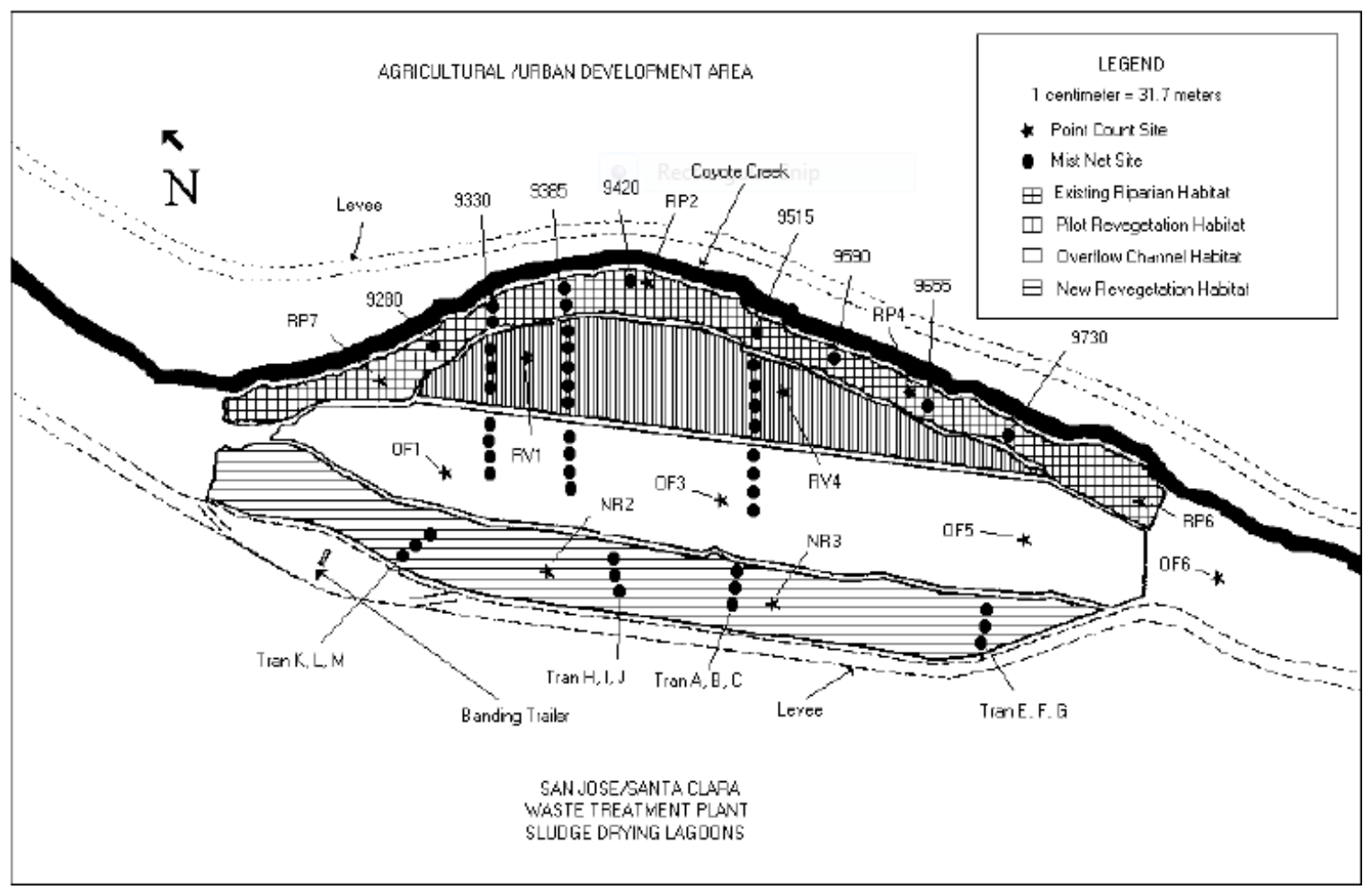

Figure 4. CCFS layout diagramming the four monitoring sites and established mist-net locations, reprinted with permission from Jaramillo et al. (1997).

The habitat and vegetation diversity within each monitoring site vary due to the previous occupation of the land for agricultural purposes. The Riparian site is set along the 8-23 m wide habitat bordering Lower Coyote Creek which contains a variety of trees of different species, ages and sizes, along with shrubs, and some native and nonnative plants (Wolf, Mewaldt, Rigney, Duke, \& Hopkins, 1989). Vegetation species in the Riparian site consist of Arundo (Arundo spp.), weeping willow (Salix babylonica), box elder (Acer negundo), blue-elderberry (Sambucus cerulean), California buckeye (Aesculus californica), California black walnut (Juglans californica), coyote brush (Baccharis pilularis), poison hemlock (Conium maculatum), California blackberry (Rubus), greater periwinkle (Vinca major) and peppergrass (Lepidium virginicum) (Taketa, 2013). The Pilot Revegetation site is a 4.3 acre plot, and was formerly used as a 
pear orchard until the SCVWD replanted the property with about 4,000 trees and shrubs of 14 different species as part of the habitat restoration component of the flood prevention projects (Jaramillo et al., 1996). Vegetation species in the Pilot Revegetation site consist of willow, box elder, poison hemlock, California blackberry, coyote brush, coast live oak (Quercus agrifolia), valley oak (Quercus lobata), California black walnut, peppergrass, black mustard (Brassica nigra), Oregon ash (Fraxinus latifolia), blue-elderberry, western sycamore (Platanus racemose), California bay (Umbellularia californica) and California buckeye (Taketa, 2013). The Overflow Channel was created by the SCVWD between 1989-1990 to minimize the risk of flooding along lower Coyote Creek, and currently consists of small herbaceous plants; woody vegetation is removed when too overgrown (Jaramillo et al., 1996; Rigney, Katano \& Otahal, 1993). Vegetation species in the Overflow Channel consist of California blackberry, peppergrass, poison hemlock, mule fat (Baccharis salicifolia), box elder, coyote brush, blue-elderberry, teasel (Dipsacus), black mustard, mugwort (Artemisia vulgaris) and bindweed (Convolvulus) (Taketa, 2013).

The New Revegetation site was created in 1993 by the SCVWD, where 25 species of trees, shrubs and plants were grown along the eight acres of land adjacent to the Overflow Channel (Rigney, Katano, \& Otahal, 1994). Today, the vegetation species in the New Revegetation Site consist of valley oak, coyote brush, willow, blue-elderberry, box elder, California bay, fig, California blackberry, caper spurge (Euphorbia lathyris), California rose (Rosa californica), poison hemlock, virgin's bower (Clematis virginiana), aster (Aster spp.), coast live oak and peppergrass (Taketa, 2013). 
CCFS lies adjacent to a popular recreational trail, the Coyote Creek Trail. People often use the Coyote Creek Trail for walking, biking, and dog-walking. Additionally, CCFS is situated near a large shopping center, McCarthy Ranch, and surrounded by a variety of frequently used highways and roadways. There is no public access to CCFS but there are surrounding neighborhoods with growing developments are present in the area. Although the role of the human dominated communities surrounding CCFS has not been readily investigated in relation to the health of the ecosystem, it is important to keep such factors in mind when implementing restoration and management studies.

Since the late 1980s the area within CCFS has been documented to be a desirable habitat for avian communities due to vegetation and resource diversity and abundance surrounding the riparian corridor. Birds from a variety of foraging guilds as well as Neotropical migrants, winter residents, and year-round residents visit or occupy the CCFS habitat annually. Due to the location of CCFS along the Pacific Flyway, the North to South route of travel for migratory birds, a variety of species have been observed at CCFS during different seasons.

Each year the fall migration brings a variety of species to CCFS, including hatchingyear (HY) Pacific-slope flycatchers (PSFL), the focal species for this study (Figure 5). 


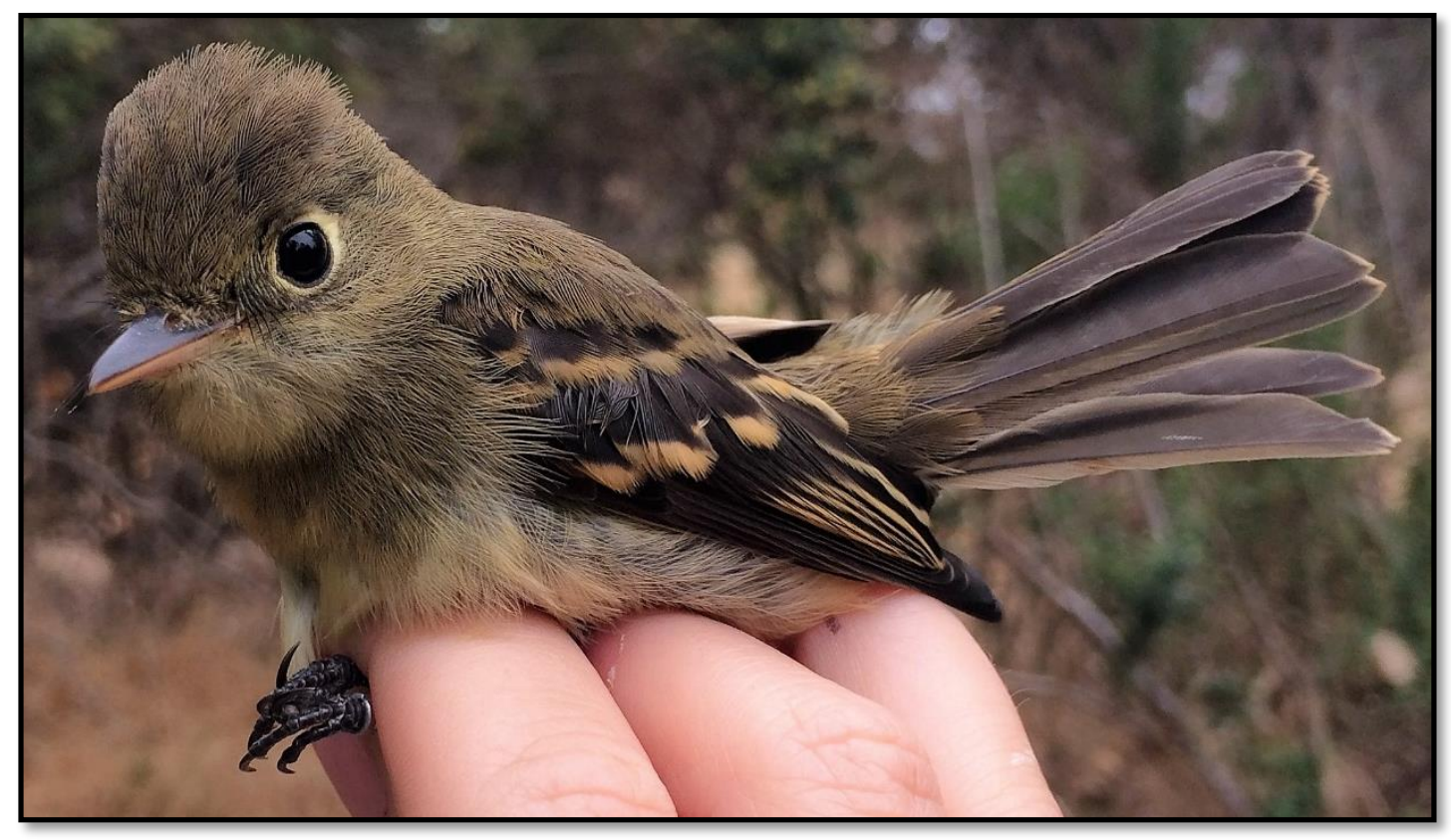

Figure 5. Photo of a hatching-year Pacific-slope flycatcher caught at the Coyote Creek Field Station. (E. Moffitt, personal photograph, September, 2014)

HY PSFL arrive at the site as early as July and stay until as late as November.

Because PSFL are primarily insectivorous, the eruptions of insects within the riparian corridor during the warm summer months make CCFS an ideal stopover site for these birds to forage. The fall migration of the HY PSFL has been very consistent over the past 15 years with between 80 and 250 birds captured at CCFS each fall (San Francisco Bay Bird Observatory, 2016).

The trend in capture rates of PSFL at CCFS over time (Figure 6) is consistent with the general declining trend of PSFL populations observed from BBS and Christmas Bird Count data. 


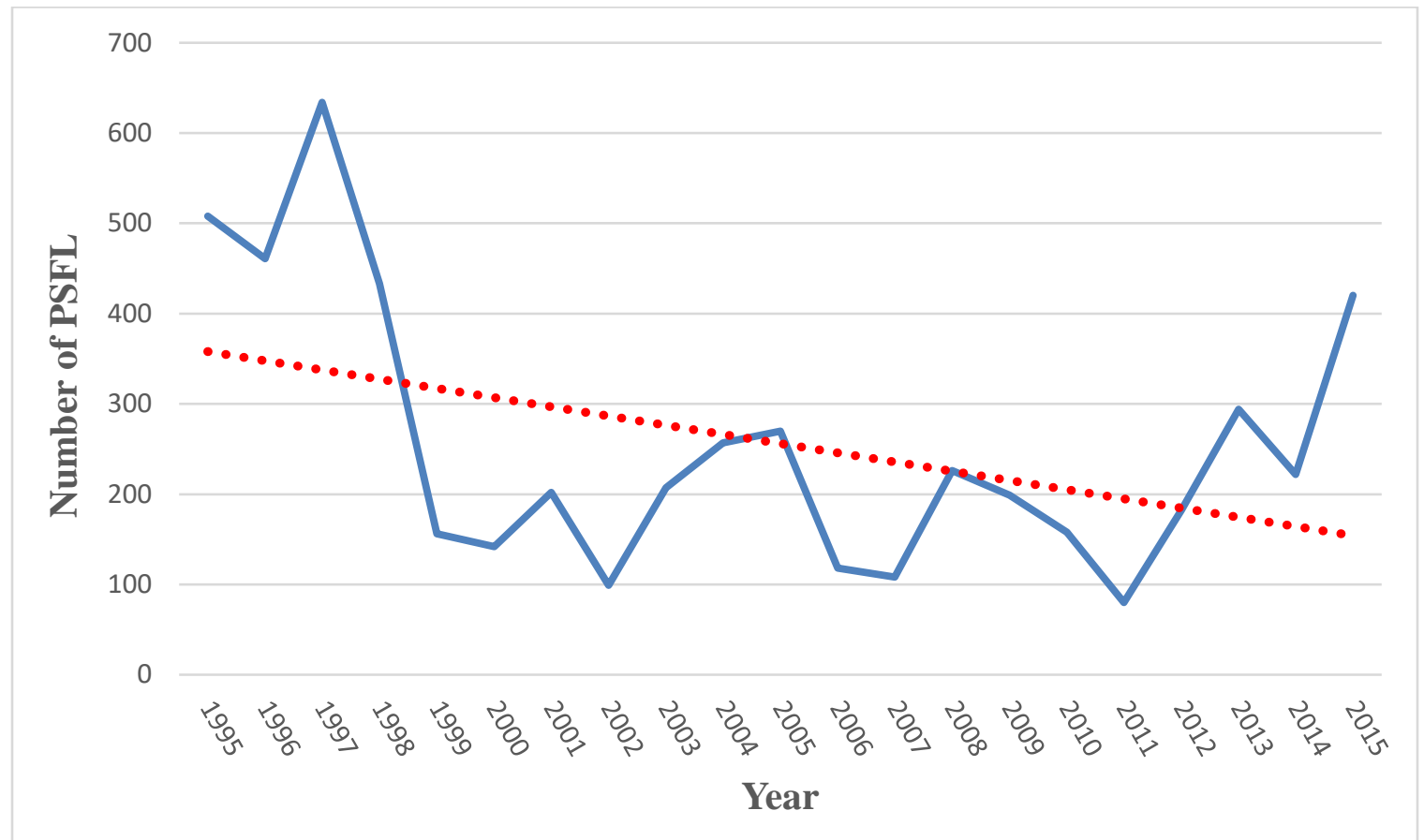

Figure 6. The total number of PSFL caught at CCFS per year from 1995 to 2015, data analyzed with permission from San Francisco Bay Bird Observatory (2016).

HY Pacific-slope flycatchers go through a partial pre-basic molt on their wintering grounds between September and December (Pyle et al., 1997). When the HY PSFL migrate south to their wintering grounds in the fall, and stopover at CCFS along the way, they are retaining their juvenile plumage. The juvenile plumage was grown in on the HY PSFL natal grounds, and the feathers contain isotopic signatures that are consistent with those in the natural environment of their natal grounds. Because HY PSFL wait to molt their feathers until they've reached their wintering grounds, they serve as ideal candidates for this study.

\section{Study Design}

To address all four research questions, I sampled HY Pacific-slope (PSFL) flycatchers at the Coyote Creek Field Station. The overall population size of PSFL is 
unknown, but each year a subset of the population migrates through the Coyote Creek Field Station banding station as the birds make their way to their southern, tropical wintering grounds. Each bird was the sampling unit for this project, with the intention of obtaining a maximum of 180 samples. Based on the previous annual capture rates of the banding station, the number of flycatchers expected to be captured at the banding station was in the range of 85 to 200 birds. Based on similar studies, (Chamberlain et al., 1997; Hobson, 1999b; Hobson, Mcfarland, Wassenaar, Rimmer, \& Goetz, 2001; Hobson \& Wassenaar, 1997; Kelly, 2006; Kelly et al., 2002; Meehan et al., 2004; Pérez \& Hobson, 2007; Rubenstein et al., 2002; Wassenaar \& Hobson, 2000b) adequate sample sizes range from 50 birds to 700 birds, depending on the number of species being examined, which component(s) of the annual cycle is being examined (breeding and/or wintering grounds), and the number of isotope signatures being investigated $\left(\delta^{2} \mathrm{H}, \delta^{13} \mathrm{C}\right.$ and/or $\left.\delta^{15} \mathrm{~N}\right)$. Generally, an average of 50 birds is sufficient for determining one origin by analyzing one isotope signature. Because this study investigated only the breeding origins of the PSFL but analyzed three isotopic signatures $\left(\delta^{2} \mathrm{H}, \delta^{13} \mathrm{C}\right.$ and $\left.\delta^{15} \mathrm{~N}\right)$, the maximum sample size was set at 180 birds.

All primary data were collected at CCFS during the summer and fall 2014 PSFL migration season which began when the first PSFL arrived (Sunday, July 20, 2014) and was ongoing until the last PSFL arrived (Sunday, October 12, 2014). Data were collected during the normal operating hours of the CCFS banding station, which were Wednesdays, Saturdays, and Sundays from a half hour before local sunrise to five hours following. The opening times varied from 5:50 to 6:30 am, and the closing times varied from 10:50 am 
to 11:30 am. Most data were collected by myself, but other data collectors included Josh Scullen (the CCFS station manager) and 21 trained volunteer bird banders. The locations of the mist nets were pre-established by SFBBO. The sampling locations (Figure 4), times, and frequency were previously designated to capture birds at different areas of each habitat type, and on different days of the week, based on volunteer availability.

Because CCFS was established to continually monitor the movement, population trends, and breeding statuses of the avian community, control groups were not necessary and did not apply to this research design. It was a common occurrence at CCFS for the same birds to be sampled and captured repeatedly due to their regular use of the habitat, but for this project the sampled PSFL were marked and, if recaptured, the data was not collected twice.

\section{Data Collection}

Field procedures. Flycatchers were caught in 48 previously-established mist net transects located within the Riparian, Pilot Revegetation, Overflow Channel, and New Revegetation sites at CCFS. Forty-seven out of 48 nets used are the TQ12 model manufactured by Avinet and are 2.6 meters high, 12 meters wide, and made of black polyester mesh. The $48^{\text {th }}$ net is the TQ06 model from Avinet and is 2.6 meters high and six meters wide. Each net is held together by two three meter poles made of two centimeter electrical conduit. On Sundays, 19 nets were opened: five within the Riparian habitat, four within the Pilot Revegetation habitat, four within the Overflow Channel, and six within the New Revegetation habitat. On Wednesdays, 15 nets were opened: three within the Riparian habitat, five within the Pilot Revegetation habitat, four within the 
Overflow Channel, and three within the New Revegetation habitat. On Saturdays, 14 nets were opened: four within the Riparian habitat, three within the Pilot Revegetation habitat, four within the Overflow Channel, and three within the New Revegetation habitat. Nets remained open during the normal operating hours of CCFS, unless weather was inclement, which included temperatures below $4.4^{\circ} \mathrm{C}$, temperatures above $26.6^{\circ} \mathrm{C}$, heavy mist, rain, flooding, winds exceeding $24 \mathrm{kh}$, if numerous predators such as feral cats, fox, bobcat, or accipiters were present, or if there were less than two people on site volunteering.

Nets were checked every 30 minutes or more often if possible. Once the birds were caught in the mist-nets, they were extracted immediately and carefully transported to the banding trailer in breathable cotton bags (Figure 7). 

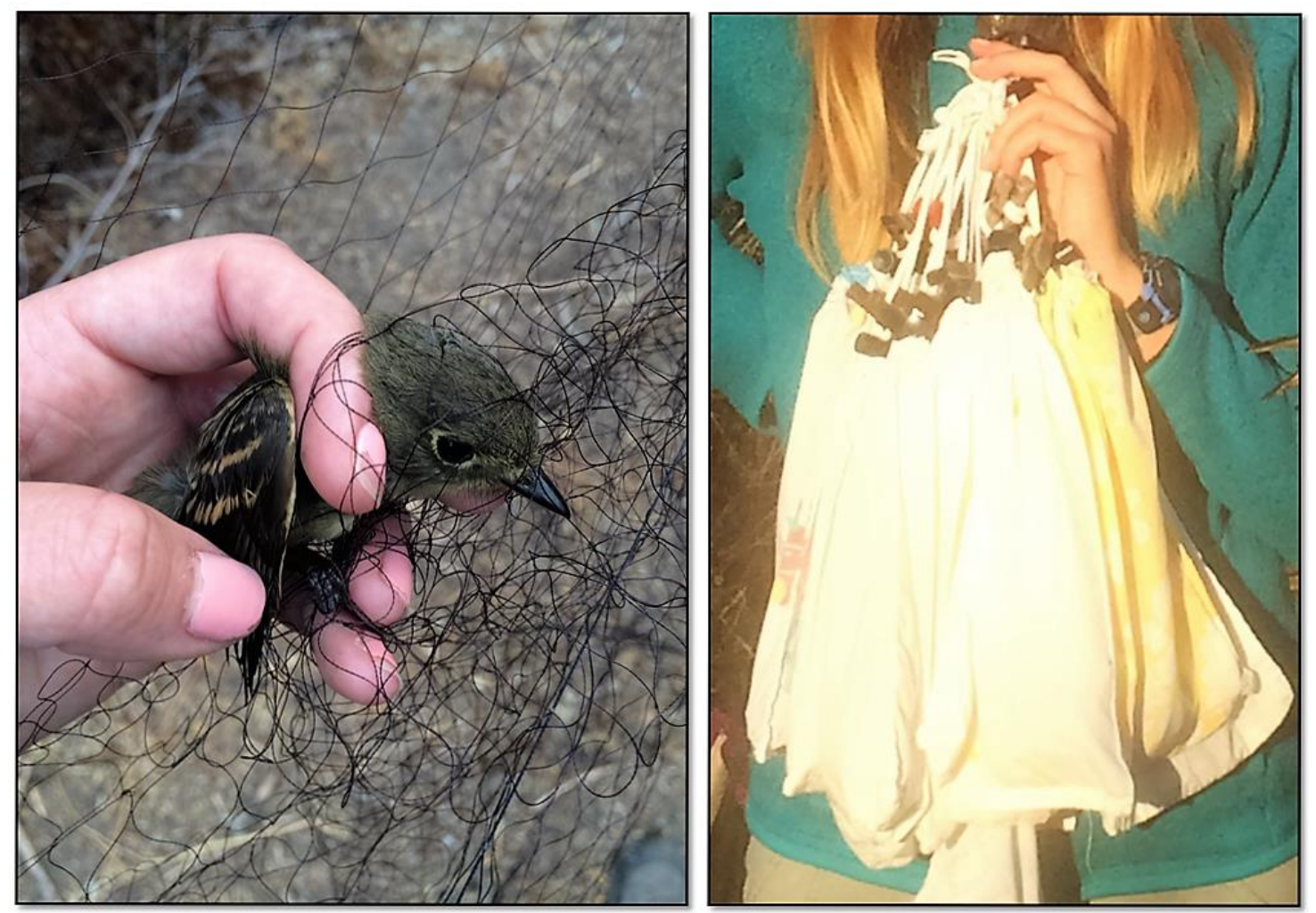

Figure 7. Photos of mist-net collection procedures at CCFS. On the left is a HY PSFL being extracted from a mist-net, and on the right are birds being transported to the banding trailer in cotton bags. (E. Moffitt, personal photographs, September, 2014).

The flycatchers were fitted with aluminum bands provided by the Bird Banding Laboratory of the U.S. Geological Survey within the Department of the Interior that had an eight- or nine- digit unique number. Morphological measurements were taken as required by the BBL standard protocol. The bands were either size 0 or $0 \mathrm{~A}$ based on the leg measurement of the individual bird. A leg gauge was used to measure the bird's leg for the correct band size and the band was placed on the bird's left leg using banding pliers and if needed band removal pliers. The species of flycatcher were identified and all measurements were recorded until species identification was confirmed. The only species which were considered for this study after being identified were the Pacific-slope flycatchers. None of the other congeners, cordilleran, willow, traill's, hammonds, least, 
dusky, gray, yellow-bellied, acadian, and western wood-pewee- were considered for this study. A wing chord ruler, a tail ruler and digital calipers were used to take all body measurements on the PSFL. As previously mentioned, western flycatcher is the previously used identification name for the Pacific-slope and cordilleran flycatchers combined, but the CCFS banding station refers to the former nomenclature in its protocol due to the extreme difficulties in differentiating between the two subspecies, and the increased chance of overlap between the two species. The following formula, which only allows distinction of 60\% of individuals (Pyle et al., 1997) created by Pyle et al. (1997) found on page 236 of the "Identification Guide to North American Birds Part 1" was used to separate the Pacific-slope flycatchers from the Cordilleran flycatchers to the best of my ability, with "p" referring to a primary feather, "s" referring to a secondary feather, "wg" referring to wing length, and "tl" referring to tail length:

$$
\begin{gathered}
([p 6-p 10]+[\text { longest } p \text { - longest } s]+[w g-t l]) X(p 9-p 5)= \\
61.7-283.5 \mathrm{~mm} \text { in Pacific-slope flycatchers } \\
\text { 157.8-331.0 mm in cordilleran flycatchers }
\end{gathered}
$$

Once flycatchers were properly identified, in addition to the date, capture time, and net location the following standard Bird Banding Laboratory (BBL) data were recorded: age, sex, how aged and sexed (based on skull, cloacal protuberance, brood patch, juv. plumage, molt limit, plumage, molt, feather wear, mouth/bill, eye color, wing length, tail length, or other), skull pneumatization level, display of breeding characteristics (cloacal protuberance or brood patch), fat, feather molt stage (body molt and flight feather molt), wing length, body mass. An optivisor (magnification device) and skulling water (tap water) were used to determine skull pneumatization level. A digital balance and weighing 
containers were used to weigh the birds. All other measurements were obtained visually. Data sheets were completed for each bird sampled (Appendix A).

For each newly banded Pacific-slope flycatcher, two tail feathers (left rectrice \#1 [LR1], an inner most tail feather, and right rectrice \#6 [RR6], an outer most tail feather), one from each side, were carefully pulled and placed in coin envelopes labelled with the capture date, band number, and species identification. If either LRI or RR6 were missing from the bird, then LR2 and RR5 were respectively pulled. If more than one of the targeted tail feathers was missing, only 1 feather was pulled. Special attention was made to handling the feather quill ends as little as possible to avoid removing any flycatcher DNA, so feathers were held by the tips, the distal end, and placed in the envelopes quill ends first, proximally. The date of feather collection was noted on the data sheets. For each recaptured Pacific-slope flycatcher, the formerly collected data on that flycatcher was checked to confirm if feathers had been previously pulled, and only birds with feathers which had not been pulled were subject to extraction.

A total of 176 Pacific-slope flycatchers were sampled and 349 tails feathers were obtained for this study.

Laboratory procedures. Feathers were stored in coin envelopes as they were collected in the cool, dry environment of San José State University’s Environmental Studies Department Graduate Laboratory. Stored feather samples were not handled until all of the samples had been collected by the end of the field season.

Once all samples had been collected, feather quills were cut and separated from the rest of the feather, and stored in coin envelopes. The quill-less feathers were placed in 
clearly labelled 20ml scintillation vials (VWR, Visalia, CA; catalogue number 66021453) and cleaned to remove surface oils following protocols by (Paritte \& Kelly, 2009; Wassenaar \& Hobson, 2000a). All cleaning procedures were conducted at San José State University in the Biology Department's PROTEIN (Proteomics Research or Training Encompassing Investigator Needs) Lab.

The quill-less feathers were cleaned once with a 1:30 solution of Fisher-Versa Clean (Fisher Scientific, Pittsburg, PA; catalogue number 04-342) detergent: deionized water, and then rinsed three times with pure deionized water. Fresh deionized water was used for each rinse cycle. Spent detergent solution and deionized water was properly discarded in hazardous waste containers as required by San José State University. The cleaned feathers were then air dried within the $20 \mathrm{ml}$ scintillation vials for 24 hours under the evacuating fume hood. Once dried, the feathers were re-cleaned by being soaked in a 2:1 chloroform: methanol (The Science Company, Denver, CO; catalogue numbers NC-0217 and NC-3495) solvent, agitated for three minutes using an Ultrasonic Cleaner (Branson 1510 Ultrasonic Cleaner) and then let to sit in the solution with vials capped and screwed tightly for 24 hours (R. Orben, personal communication, March 11, 2014). After 24 hours the liquid was poured out and properly disposed of, and feathers were rinsed twice with a fresh 2:1 chloroform: methanol solution. The spent rinse was then properly disposed of, and the feathers were left in solution-free open top vials to dry for 48 hours in the fume hood. After cleaning, dried feathers were stored in solution-free open top vials in sealed Tupperware containers lined with Silica Gel Dessicant packets (Uline, Pleasant Prairie, WI; catalogue number S-3906) to prevent moisture buildup. 
Cleaned feather samples were then cut, weighed, and encapsulated in preparation for analysis (Figure 8).
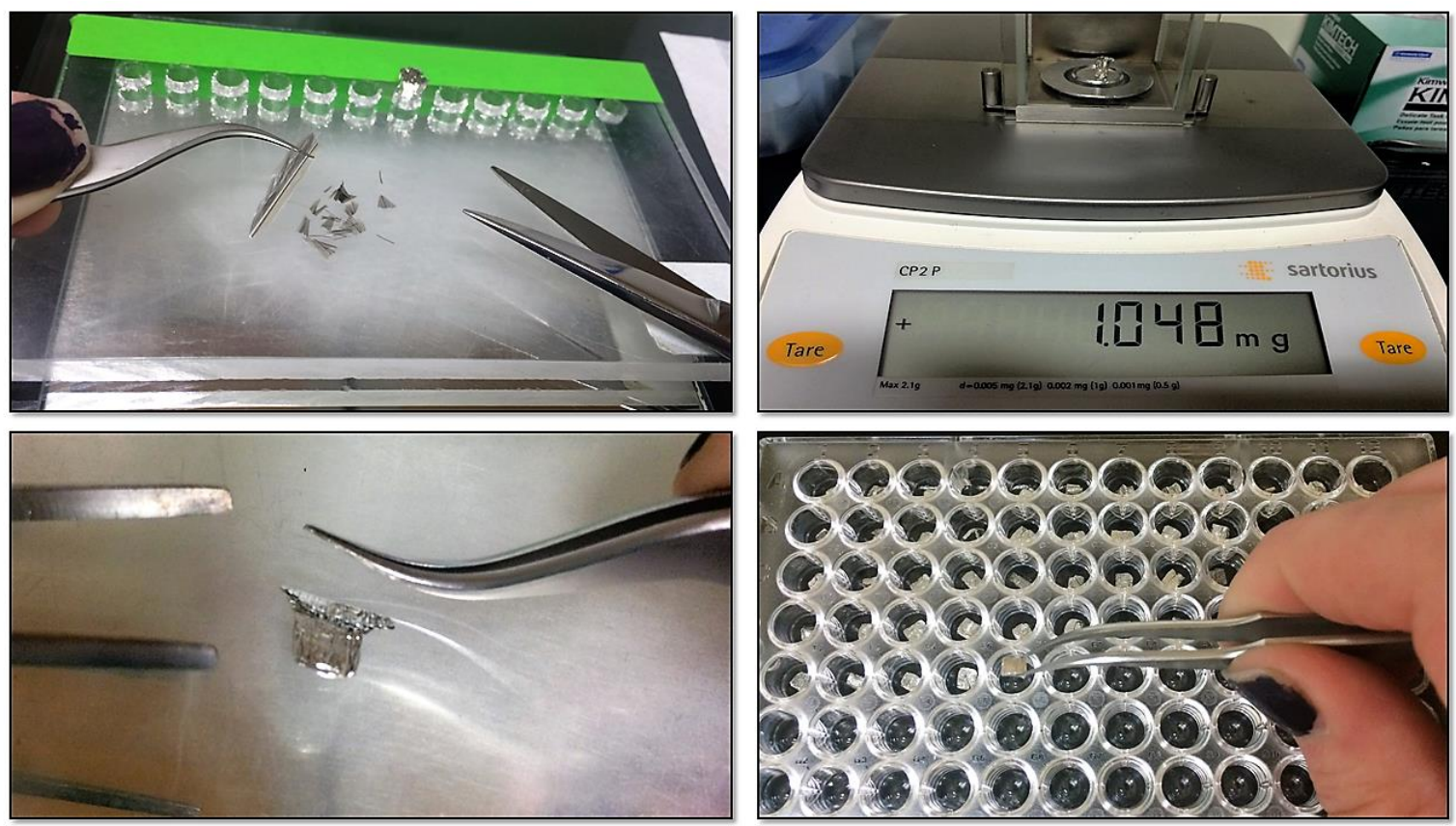

Figure 8. Photos of sample preparation procedures. On the top left feathers are being cut and placed in a capsule; on the top right feather pieces are weighed in a capsule; on the bottom left the capsule containing the feather pieces is encapsulated into a small ball; and on the bottom right finished samples are placed into a 96 well plate. (E. Moffitt, personal photographs, February, 2015).

Approximately $75 \mathrm{ug}$ of hydrogen, $125 \mathrm{ug}$ of carbon and $500 \mathrm{ug}$ of nitrogen needed to be extracted from the cleaned feathers to conduct hydrogen $(\mathrm{D} / \mathrm{H})$, carbon $\left({ }^{13} \mathrm{C}:{ }^{12} \mathrm{C}\right)$, and nitrogen $\left({ }^{15} \mathrm{~N}:{ }^{14} \mathrm{~N}\right)$ stable isotope analysis. Hydrogen $(\mathrm{D} / \mathrm{H})$ analyses were conducted separately from carbon and nitrogen analysis, so samples were prepared separately. For both analyses, necropsy scissors were used to cut a 0.1-0.2 mg sample of material containing both vane and rachis from the distal end of each feather sample. For hydrogen analysis, every $8^{\text {th }}$ sample (individual bird), was prepared twice, and for carbon and nitrogen analyses, every $12^{\text {th }}$ sample was prepared twice. The purpose of this was to 
include replicate samples as recommended by the U.C. Davis Stable Isotope Facility for the purpose of checking analytical precision. Due to complications with laboratory preparation, 7 samples (individual birds) were removed from the study. A total of 374 samples including replicates were prepared for hydrogen, carbon and nitrogen stable isotope analyses.

Samples were weighed and placed using fine surgical forceps into 3.5 x $5.0 \mathrm{~mm}$ silver capsules (Costech, Valencia, CA; catalogue number 041066) for hydrogen analysis and 5.0 x $9.0 \mathrm{~mm}$ tin capsules (Costech, Valencia, CA; catalogue number 041061) for carbon and nitrogen analysis. Of the 374 samples, 173 were weighed to the nearest $.001 \mathrm{mg}$ using a guest micro-analytical balance (Sartorius Microbalance with internal calibration, $\mathrm{CP} 2 \mathrm{P}$ model) at the University of California Davis Stable Isotope Facility in Davis, California. The remaining 201 samples were weighed to the nearest $0.1 \mathrm{mg}$ using Dr. Alexander Gershenson's analytical balance (O'Haus Pioneer Analytical Balance, model \# PA2201) at located in room 51 of the Science Building at San José State University.

Once in the silver and tin capsules, samples were crimped and encapsulated into a small, compact spherical ball. Capsule openings were folded over several times to compress the samples and remove any trapped air. Because feather material is extremely rigid and the capsules are delicate, there were multiple incidences in which feather material punctured the capsule walls. These samples were wrapped in a second silver or tin capsule. Of the 374 samples, 225 were wrapped in two capsules. Finally, encapsulated samples were placed into separate pre-labeled wells of 96-well trays (Electron 
Microscopy Sciences, Hatfield, PA; catalogue number 70437-R1) for hydrogen and carbon/nitrogen analyses.

Stable hydrogen, carbon, and nitrogen analysis of the feather samples occurred at the University of California Davis Stable Isotope Facility in Davis, California between February 2015 and January 2016. One hundred and ninety-one samples were analyzed for deuterium: hydrogen ratios, and 183 samples were analyzed simultaneously for ${ }^{13} \mathrm{C}:{ }^{12} \mathrm{C}$ and ${ }^{15} \mathrm{~N}:{ }^{14} \mathrm{~N}$ ratios.

The hydrogen samples were stored by the U.C. Davis Stable Isotope Facility for a 96 hour equilibration period as described by (Wassenaar \& Hobson, 2003) to avoid complications associated with the potential exchange of hydrogen in the feather samples with ambient water vapor (U.C. Davis Stable Isotope Facility, 2014b). Carbon and nitrogen samples were analyzed upon receipt.

Hydrogen samples were analyzed using an elementar PyroCube (Elementar Analysensysteme GmbH, Hanau, Germany) interfaced to an Isoprime VisION isotope ratio mass spectrometer (Isoprime Ltd., Stockport, UK) (U.C. Davis Stable Isotope Facility, 2014b). Samples were incinerated at $1450^{\circ} \mathrm{C}$, to convert solid material to hydrogen gas using a glassy carbon and graphite felt filled ceramic reactor (U.C. Davis Stable Isotope Facility, 2014b). Carbon and nitrogen samples were analyzed using a PDZ Europa ANCA-GSL elemental analyzer interfaced to a PDS Europa 20-20 isotope ratio mass spectrometer (Sercon Ltd., Cheshire, UK) (U.C. Davis Stable Isotope Facility, 2014b). Samples were combusted at $1000^{\circ} \mathrm{C}$ in a chromium oxide and silvered copper oxide filled reactor and then removed in a reduction reactor (reduced copper at $650^{\circ} \mathrm{C}$ ) 
(U.C. Davis Stable Isotope Facility, 2014b). A helium carrier then flowed through a water trap (magnesium perchlorate), and nitrogen gas and carbon dioxide were separated on a Carbosieve $\mathrm{GC}$ column $\left(65^{\circ} \mathrm{C}, 65 \mathrm{~mL} / \mathrm{min}\right)$ before entering the IRMS (U.C. Davis Stable Isotope Facility, 2014b).

To determine the hydrogen, carbon and nitrogen isotope ratios of the PSFL samples, reference samples with known values were analyzed simultaneously, and the results were corrected based on the known values of the analyzed laboratory standards (U.C. Davis Stable Isotope Facility, 2014b). For hydrogen analysis, turkey keratin (TRK) was selected as the laboratory standard due to its similar composition to the PSFL feather samples, and was interspersed during analysis for every four PSFL samples to correct for drift. The TRK laboratory standard was calibrated against Polyethylene Powder, an accepted material in substitution of the International Reference Material IAEA-CH7, and two keratin working standards Kudu Horn (KHS) and Caribou Hoof (CBS). Polyethylene powder was interspersed between PSFL samples for the purpose of size correction and calculating elemental totals, while KHS and CBS standards were interspersed for normalization correction purposes. Additionally, Bowhead Whale Baleen (BWB) was used for check standardization. Similar corrections were made for carbon and nitrogen analysis with Bovine Liver, Nylon 5, and Glutamic Acid laboratory standards scattered throughout the PSFL samples. These standards were calibrated against the National Institute of Standards and Technology (NIST) Standard Reference Material USGS-41.

Preliminary hydrogen, carbon, and nitrogen isotope ratios were measured in relation to the reference standards analyzed (U.C. Davis Stable Isotope Facility, 2014a). As 
described by Joy Matthews, the laboratory manager at the U.C. Davis Stable Isotope Facility, the long term precision, reported as SD, for $\delta^{2} \mathrm{H}$ is $<3 \%$ (J. Matthews, personal communication, May 15, 2016). Precision standard deviations were $0.2 \%$ for $\delta^{13} \mathrm{C}$ and $0.3 \%$ for $\delta^{15} \mathrm{~N}$. The final stable isotope ratios (deuterium to hydrogen; ${ }^{13} \mathrm{C}$ to ${ }^{12} \mathrm{C} ;{ }^{15} \mathrm{~N}$ to ${ }^{14} \mathrm{~N}$ ) were calculated by correcting all values in the analyses based on the known values of the simultaneously run laboratory standards (U.C. Davis Stable Isotope Facility, 2014a). Ratios were reported in parts per thousand $(\% 0)$ written in delta $(\delta)$ notation, relative to the international standard V-SMOW (Vienna Standard Mean Ocean Water) for hydrogen, V-PDB (Vienna PeeDee Belemnite) for carbon, and air for nitrogen (U.C. Davis Stable Isotope Facility, 2014). The following equation was used for both analyses:

$$
X=\left\{\left[\left(R_{\text {sample }} / R_{\text {standard }}\right)-1\right] \text { X } 1,000\right\},
$$

where $X$ is the final isotope ratio for the PSFL samples (deuterium:hydrogen, ${ }^{13} \mathrm{C}:{ }^{12} \mathrm{C}$, ${ }^{15} \mathrm{~N}:{ }^{14} \mathrm{~N}$ respectively), $R_{\text {sample }}$ is the preliminary isotope ratio for the PSFL samples, and $R_{\text {standard }}$ is the known isotope ratio of the laboratory standards.

Secondary data. Three secondary datasets were obtained for use in the assignment to probable breeding origins process. The first was a set of isotopic data obtained to provide a basis for comparing feather deuterium $\left(\delta^{2} \mathrm{H}_{\mathrm{f}}\right)$ and growing season precipitation $\left(\delta^{2} \mathrm{H}_{\mathrm{fp}}\right)$ when assigning PSFL to probable breeding origins. A previously constructed model of the "amount- weighted growing season $\delta^{2} \mathrm{H}$ in precipitation of North America" in the form of a georeferenced ArcGIS raster was obtained from Bowen et al. (2005) on waterisotopes.org. Data for the models was obtained from the Global Network of Isotopes in Precipitation (GNIP) database within the Water Resources Programme of the 
International Atomic Energy Agency (IAEA). Data from GNIP has been collected since 1961 when the IAEA in collaboration with the World Meteorological Organization (WMO), national meteorological services, national authorities and scientific volunteers established 1,000 research stations across the United States and other countries to collect monthly weighted average precipitation samples for analysis of deuterium and oxygen-18 in the environment (International Atomic Energy Agency, 2014). It was unclear how the precipitation research stations were chosen, but it was presumed that the stations were established to sample a variety of climate types throughout the United States and other countries. At each station, deuterium in weighted average precipitation samples were taken from a total precipitation amount that was collected monthly (International Atomic Energy Agency, 2014). The models created by Bowen et al. (2005) used all the precipitation sample values from the GNIP database to calculate un-weighted (versus the provided weighted) averages for each month, which created representations of the average deuterium in precipitation for an entire year (Bowen et al., 2005).

The second dataset obtained was a digital map of the distribution of Pacific-slope flycatchers for constraining probable breeding origins. A shapefile was requested from BirdLife International and NatureServe (2015). Data to compile these maps were obtained by BirdLife International from multiple sources including the following: museum specimen localities; 587,000 point localities for 6,800 species in the BirdLife International Point Locality Database; 5.02 million records for 8,600 species in the Global Biodiversity Information Facility; observer records from the BirdLife International's Red Data Books and species factsheets; 300,000 records for 7,000 species 
of documented occurrences in 10,000 defined Important Bird and Biodiversity areas from BirdLife International's World Biodiversity Database; published literature, survey reports, and other unpublished sources; distribution atlases from systematic surveys, distribution maps in field guides, and expert opinion (BirdLife International and NatureServe, 2015).

The third dataset obtained was a digital map of the North American Breeding Bird Survey Relative Abundance results for Pacific-slope flycatchers and cordilleran flycatchers from 1966-2012 for constraining probable breeding origins. A shapefile was obtained from Sauer et al. (2014) through the USGS Patuxent Wildlife Research Center Migratory Bird Research online database. The North American Breeding Bird Survey is an annual protocol orchestrated by the Patuxent Wildlife Research Center of the U.S. Geological Survey in which qualified observers conduct Breeding Bird Surveys throughout North America during the highest point in the nesting season (Sauer, Hines, Gough, Thomas, \& Peterjohn, 1997). The surveys have been conducted in June of each year since 1966 (Sauer et al., 1997). Observers visited random pre-established habitats throughout a region and conducted point-counts for three minutes every 0.5 miles (Sauer et al., 1997). All birds that were seen and/or heard within a 0.25 mile radius of the point were counted during the three-minute survey (Sauer et al., 1997). The results of these annual surveys were published in the North American BBS Relative Abundance network, and were not comprehensive totals of breeding bird populations, but rather representations of a species' spatial concentration during the breeding season (Sauer et al., 1997). 


\section{Data Analysis}

Assignments to breeding origin. Descriptive statistics were used to calculate average $\delta^{2} \mathrm{H}$ values for the sample. Prior to making geographic assignments to breeding origins, a Shapiro-Wilk test of normality was applied to determine if the $\delta^{2} \mathrm{H}$ of PSFL sampled at CCFS came from a normally distributed population. To determine if there was a relationship between the migration origin (latitude specific) of the HY PSFL passing through CCFS during the fall of 2014 and the capture date of the birds, linear models were fitted with capture dates as the independent variables, and $\delta^{2} \mathrm{H}$ values as the dependent variables. The significance level for all statiscal analyses was set at $P<0.05$. All statistical analyses were performed in RStudio version 3.2.3 (R Core Team, 2015).

Geographic assignments to breeding origin were performed in RStudio version 3.2.3 (R Core Team, 2015) using scripts which employed the "raster" (Hijmans et al., 2016), “maps" (Becker, Wilks, Brownrigg, Minka, \& Deckmyn, 2016) and "maptools" (Bivand et al., 2016) packages.

Group assignment to breeding origin (Q1). To portray the most probable breeding origins of the southern bound migratory HY Pacific-slope flycatchers sampled at a stopover site, CCFS, a spatially explicit likelihood-based assignment technique (Hobson, 2009; Royle \& Rubenstein, 2004; Van Wilgenburg \& Hobson, 2011; Wunder, 2010, 2012) was used following the steps designed by (Van Wilgenburg \& Hobson, 2011). Likelihood-based assignment methods have been used in many animal migration studies (Arizaga et al., 2016; Hobson et al., 2014, 2015; Holberton, Van Wilgenburg, Leppold, \& Hobson, 2015; Wunder, 2010, 2012; Wunder \& Norris, 2008) to deduce migratory origin. 
Likelihood-based assignments follow a Bayesian framework to evaluate the probability that an assigned origin is the true location of that origin for a sample evaluated with measured $\delta^{2} \mathrm{H}$ (Bowen, Liu, Vander Zanden, Zhao, \& Takahashi, 2014).

I obtained a georeferenced ArcGIS raster of the amount-weighted growing season $\delta^{2} \mathrm{H}$ in precipitation of North America as reported in Bowen et al. (2005) from waterisotopes.org. When downloaded, the file was in the form of an adf file, but with the assistance of Steven Van Wilgenberg the .adf file was converted into an .asc file using ArcGIS. This ascii raster file was then imported into RStudio, as a step in the assignment model script created by Van Wilgenburg \& Hobson (2011). Additionally, a shape file of the North American and Mexico State boundaries, obtained from Steven Van Wilgenberg, was imported into RStudio as a shape file. The "raster" (Hijmans et al., 2016), "maps" (Becker et al., 2016) and "maptools" (Bivand et al., 2016) packages were used to import, plot and add country/state boundaries to the amount-weighted growing season $\delta^{2} \mathrm{H}$ in precipitation of North America raster from Bowen et al. (2005).

Because of the known isotopic discrimination of $\delta^{2} \mathrm{H}$ that occurs when $\delta^{2} \mathrm{H}$ in precipitation is metabolized into an animals' tissues, it was critical to convert the amount-weighted growing season $\delta^{2} \mathrm{H}$ in precipitation of North America raster from Bowen et al. (2005) into a raster that demonstrates a prediction of what the $\delta^{2} \mathrm{H}$ in feathers of PSFL grown in at various origins would reflect. A linear model would be conducted, and it was recommended that feathers from birds of known origins are used as the dependent variable. Known-origin feather isotope ratios would be regressed against the amount-weighted growing season $\delta^{2} \mathrm{H}$ in precipitation of North America ratios. The 
resulting algorithm would be used to calibrate the amount-weighted growing season $\delta^{2} \mathrm{H}$ in precipitation of North America raster, and convert the map into a "feather isoscape" for making assignments. For this study, PSFL feathers from known-origins were not available due to limited feasibility for obtaining samples, an inadequate sample size of available known-origin samples, and the uncertainty behind the accuracy of sample origin. Published calibration algorithms have been generated from studies that investigated biological factors and avian life history traits. Hobson, Van Wilgenburg, Wassenaar, \& Larson (2012) used data from the Avian Life History Information Database and Birds of North America Species Account Database to create categories of species based on:

1) foraging guild (insectivore, omnivore)

2) foraging substrate (ground foragers versus species foraging elsewhere [in shrubs, canopy or aerially; hereafter non-ground foragers])

3) migratory guild (Neotropical migrant, short-distance migrant, resident)

4) whether the species was associated with an aquatic versus upland habitat.

Hobson et al. (2012) modeled variation in $\delta^{2} \mathrm{H}$ based on the determined species categories, and published the following equation for use in calibrating the amountweighted growing season $\delta^{2} \mathrm{H}$ in precipitation of North America raster from Bowen et al. (2005) for Neotropical migrant non-ground foraging songbirds:

$$
\delta^{2} \mathrm{H}_{\mathrm{f}}=-27.0894+0.9527(* \mathrm{GSD})
$$

where (GSD) are the $\delta^{2} \mathrm{H}$ in precipitation of North America raster values. Several studies (Garcia-Perez \& Hobson, 2014; Garcia-Perez, Hobson, Powell, Still, \& Huber, 2013; Haché, Hobson, Bayne, Van Wilgenburg, \& Villard, 2014; Pillar, Marra, Flood, \& 
Reudink, 2016) have used the published algorithms from Hobson et al. (2012) to calibrate the amount-weighted growing season $\delta^{2} \mathrm{H}$ in precipitation of North America raster from Bowen et al. (2005) when making assignments. The above equation was entered into RStudio to calibrate the previously generated amount-weighted growing season $\delta^{2} \mathrm{H}$ in precipitation of North America raster resulting in model (hereafter feather isoscape) of the predicted $\delta^{2} \mathrm{H}$ in feathers $\left(\delta^{2} \mathrm{H}_{\mathrm{f}}\right)$. The corresponding standard deviation of the calibration model residuals for Neotropical migrant non-ground foraging songbirds $(\mathrm{SD}=$ $14.4 \%$ ) from Hobson et al. (2012) was also entered for estimating variance in the assignments.

Because PSFL are only known to be found within the Pacific coast states (California, Oregon and Washington), Alaska, and Coastal/ Southern British Columbia (Lowther, 2000), likelihood-based assignments results in RStudio were restricted to conceivable origins within the species' distribution range. A shape file of the PSFL geographic extent was obtained from Bird Life International and Nature Serve (2015) and imported into RStudio. The spatial "mask" and "crop" operations within the "raster" package (Hijmans et al., 2016) were used to reduce the feather isoscape to only areas within the PSFL distribution range.

Following the isoscape calibration and masking, a normal probability density function was used to evaluate the possibility of a region within the isoscape denoting a potential migratory origin for the PSFL samples (Van Wilgenburg \& Hobson, 2011). After the isoscape was calibrated in RStudio the boundaries within the isoscape were divided into cells. The normal probability density function serves as an equation that evaluates the 
likelihood of each cell within the isoscape being a migratory origin given the expected mean of a cell and the expected level of variance in $\delta^{2} \mathrm{H}$ (Van Wilgenburg \& Hobson, 2011). Again, the expected level of variance was derived from the reported standard deviation ( $\mathrm{SD}=14.4 \%$ ) from Hobson et al. (2012) for Neotropical migrant non-ground foraging songbirds who grew their feathers in at the same site.

The resulting probability densities for each cell of the isoscape were reported as individual maps, in a way that did not sum to a whole value, or one, uniformly across the isoscape (Van Wilgenburg \& Hobson, 2011). To correct for this the data had to be normalized and rescaled to sum to one by obtaining the cumulative sum of each cell's probability within the isoscape, and then dividing by that value to create one uniform map of each cell's probability of origin (Van Wilgenburg \& Hobson, 2011). The resulting probability of origin surfaces for each individual bird were then stacked into one vector.

The individual birds were then assigned to the calibrated isoscape using an "odds ratio approach" (Hobson, Wunder, Van Wilgenburg, Clark, \& Wassenaar, 2009; Van Wilgenburg \& Hobson, 2011; Wunder, 2007). The "odds ratio approach" is an alternative method of making spatially explicit assignments to the historically implemented "cumulative probabilities approach" which examines an entire sample set's migration origin by determining cumulative probabilities from the individual samples' (or birds) probability densities (Van Wilgenburg \& Hobson, 2011). It has been found that the cumulative probabilities approach creates sources for error in assignments when the sample set has a possibility of originating from bimodal or multimodal migration origins; the spatially explicit results do not fully depict all potential sites of origin (Van 
Wilgenburg \& Hobson, 2011). The "odds ratio approach" follows the cumulative probability method by first determining individual probability surfaces, then extracting only a small quantity of the previously calculated probability distribution (Van Wilgenburg \& Hobson, 2011). The extracted proportion of the cumulative probability distribution is then used to signify the "likely" origins of the individual birds, and the remaining cumulative probabilty surfaces are incorporated to represent the "unlikely" origins (Hobson et al., 2009; Van Wilgenburg \& Hobson, 2011; Wunder, 2007). The displays of the "likely" versus "unlikely" individual representations of origins are then totaled to exhibit the "likely" versus "unlikely" spatially explicit origins of the sample as a whole (Hobson et al., 2009; Van Wilgenburg \& Hobson, 2011; Wunder, 2007).

The vector of individual probability of origin surfaces were then assigned to the calibrated isoscape using the "odds ratio approach" (Hobson et al., 2009; Van Wilgenburg \& Hobson, 2011; Wunder, 2007). To do this, a new data frame of the estimated origins from each individual probability surface was created and edited to align the results with individual sample numbers for the purpose of acting as a factor in subsequen probability density determination (Van Wilgenburg \& Hobson, 2011). The new data frame sets up an environment where, based on the chosen odds ratio, a basis for calculating the "likely" versus "unlikely" probability densities can be determined (Van Wilgenburg \& Hobson, 2011). The odds ratio chosen was 2:1, which means that the odds of any given assigned origin being correct is $67 \%$, and the odds of any given assignment being incorrect is $33 \%$. A more conservative odds ratio, i.e. a ratio above 5:1, would decrease the risk of making incorrect assignments by assigning birds to a larger range of 
potential geographical origins (Van Wilgenburg \& Hobson, 2011). A more liberal odds ratio, i.e. a ratio below 2:1, would increase the risk of making incorrect assignments by assigning birds to a narrow range of potential geographic origins (Van Wilgenburg \& Hobson, 2011). The application of different odds ratios was investigated by (Van Wilgenburg \& Hobson, 2011) using known-origin data for validation, and it was concluded that the selection of an odds ratio between 4:1 and 2:1 would provide sufficient probability of correct assignment percentages, and results that are reflective of accurate migration origins. Similar migratory connectivity studies (Hobson et al., 2014, 2015; Hobson, Van Wilgenburg, Ferrand, Gossman, \& Bastat, 2013; Holberton et al., 2015) employed a 2:1 odds ratio.

Once the odds ratio was defined in $\mathrm{R}$, a spline function was executed to select only the upper $67 \%$ of cumulative probabilities from the new data frame (Van Wilgenburg \& Hobson, 2011). This was done in R with a "predict smooth spline" function that fit a spline curve to the pre-determined cumulative probabilties of the sample, and set a cutoff point where the selected odds of $67 \%$ had been reached (Van Wilgenburg \& Hobson, 2011). With the cumulative probability cutoff determined, the individual probability of origin densities were then re-assigned into two groups; likely origins (1) or unlikely origins (0); using the "reclassify" function within the Raster package of R (Van Wilgenburg \& Hobson, 2011). Finally, the resulting list of re-classified individual assignments, individual maps, were combined to form a "raster stack" using the "Raster Stack" function of the "raster" package (Hijmans et al., 2016) in RStudio, a multi-layer collection of maps (Van Wilgenburg \& Hobson, 2011). The individual assignment 
surfaces were then summed and plotted on the isoscape to portray the distribution of breeding origins for the entire PSFL sample as a population (Van Wilgenburg \& Hobson, 2011).

Incorporation of BBS Abundance data (Q1). The reliance on stable isotope data (specifically $\delta^{2} \mathrm{H}$ ) alone in making likelihood-based spatially explicit assignments can be unreliable and problematic, and most significantly lacks information about population distributions (Royle \& Rubenstein, 2004). An alternative to analyzing stable $\delta^{2} \mathrm{H}$ data alone is the incorporation of species relative abundance data.

Knowing that PSFL migrate from their northern breeding ranges to their southern tropical wintering grounds in the fall (Lowther, 2000) it is assumed that the birds migrating through the Coyote Creek Field Station are representative of the entire PSFL breeding population. North American BBS Relative Abundance Data has been incorporated into spatially explicit likelihood-based assignment methods and treated as a prior probability with the goal of highlighting the regions where the birds were most prevalent during breeding season (González-Prieto et al., 2011; Hobson et al., 2014; Royle \& Rubenstein, 2004). This method follows Bayes Rule in which the final likelihood-based assignments are established from not only the probability of breeding origin given the $\mathrm{d} 2 \mathrm{hf}$ values, but also given the prior Relative Abundance Breeding distribution for PSFL (Royle \& Rubenstein, 2004).

Relative Abundance shapefiles for PSFL were obtained from (Sauer et al., 2014). In order to use the above spatially explicit likelihood-based script in RStudio, the Relative Abundance shapefiles had to be in a raster format and the geographic resolution had to 
match that of the amount-weighted growing season $\delta^{2} \mathrm{H}$ in precipitation of North America isoscape (Bowen et al., 2005) exactly. With the assistance of Steve Van Wilgenberg, Relative Abundance shape files were re-projected to the WGS1984 (latitude/longitude) projection in Arc Map (S. Van Wilgenburg, personal communication, February 17, 2016). The polygon to raster conversion tool was then used to force the resolution of the Relative Abundance shape file to match the cell sizes of the amount-weighted growing season $\delta^{2} \mathrm{H}$ in precipitation of North America isoscape from Bowen et al. (2005) (S. Van Wilgenberg, personal communication, February 17, 2016). The final raster was converted to an ascii format (S. Van Wilgenberg, personal communication, February 17, 2016).

The new relative abundance raster file was imported into RStudio to run the additional likelihood-based assignment. The same steps as the previous assignment model were implemented with the following minor adjustments:

- The precipitation isoscape was cropped by the boundaries of the relative abundance raster.

- Two additional steps were implemented for formatting purposes. To force the geographical extent of the isoscape to match that of the abundance raster, the "extent" function within the "raster" package (Hijmans et al., 2016) was used.

- To make sure the model properly identified the relative abundance raster as a prior probability, the abundance raster had to be normalized. The "cellStats" function of the "raster" package (Hijmans et al., 2016) was used to divide by the sum of all of the values in the relative abundance raster. 
- Before finalizing the likelihood assignments, the relative abundance raster was called to be the prior probability surface.

Incorporation of temporal data (Q2). Additional sets of spatially explicit likelihood-based assignments were investigated based on the arrival timing of the HY PSFL passing through CCFS. The $\delta^{2} \mathrm{H}$ values were first partitioned into two groups: birds captured during the first half of the season $(7 / 20 / 14-8 / 30 / 14, n=58)$, and birds captured during the second half of the season $(8 / 31 / 14-10 / 12 / 14, n=111)$. Deuterium values were then partitioned into 13 separate data sets organized by capture week starting with the date that the first HY PSFL arrived at CCFS (7/20/2014) and the date that the last HY PSFL arrived at CCFS (10/12/2014) during the fall 2014 southbound migration. Because the CCFS banding station only operates on Sundays, Wednesdays, and Saturdays, the data that was collected is only reflective of these 3 days per week. The 13 spatially explicit likelihood-based assignments were conducted in RStudio version 3.2.3 (R Core Team, 2015) using the previously described script and methodology of (Van Wilgenburg \& Hobson, 2011).

Habitat selection (Q3). To examine if there were natural groupings of individuals based on similarities between their feather $\delta^{2} \mathrm{H}, \delta^{13} \mathrm{C}$, and $\delta^{15} \mathrm{~N}$ values, I ran a Cluster Analysis based on methodolgies presented by (Reudink et al., 2015). As previously discussed, $\delta^{2} \mathrm{H}, \delta^{13} \mathrm{C}$, and $\delta^{15} \mathrm{~N}$ signatures represent probable breedng origin, habitat composition, and trophic level, respectively. By investigating potential relationships between these three elements, the breeding origin habitat type can be further characterized. Cluster analysis examines data on a multivariate level by determining if 
there are any natural groupings present based on measurements of similarity and dissimilarity and defining the number of clusters the data should be sorted into (Quinn \& Keough, 2002). Similar studies (Garcia-Perez \& Hobson, 2014; Reudink et al., 2015) have used cluster analysis for this purpose. 167 samples (individual birds) were examined for this analysis. Samples (individual birds) that did not have feather isotope values for all three elements, $\delta^{2} \mathrm{H}, \delta^{13} \mathrm{C}$, and $\delta^{15} \mathrm{~N}$, were eliminated.

Prior to conducting Cluster Analyses, mean isotopes ratios were calculated for $\delta^{2} \mathrm{H}$, $\delta^{13} \mathrm{C}$, and $\delta^{15} \mathrm{~N}$ using descriptive statistics. Linear regressions were conducted to examine if there were correlations among $\delta^{2} \mathrm{H}$ and $\delta^{13} \mathrm{C}$ isotope values, $\delta^{2} \mathrm{H}$ and $\delta^{15} \mathrm{~N}$ isotope values, and $\delta^{13} \mathrm{C}$, and $\delta^{15} \mathrm{~N}$ isotope values. In preparation for subsequent multivariate analyses, $\delta^{2} \mathrm{H}, \delta^{13} \mathrm{C}$, and $\delta^{15} \mathrm{~N}$ feather isotope values were standardized by subtracting by each variable's mean and dividing by each variable's standard deviation. Standardization is a common practice employed prior to multivariate analysis to ensure that all variables, likely measured at different scales, are weighed equally, and to minimize sources of error (Milligan \& Cooper, 1988; Quinn \& Keough, 2002).

All statistical analyses were performed in RStudio version 3.2.3 (R Core Team, 2015) using scripts which employed the "RVAideMemoire" (Hervé, 2016), "chemometrics" (Filzmoser \& Varmuza, 2016), "NbClust” (Charrad, Ghazzali, Boiteau, \& Niknafs, 2015) “mclust” (Fraley, Raftery, Scrucca, Murphy, \& Fop, 2016) and "scatterplot3D” (Ligges, Maechler, \& Schnackenberg, 2016) packages. To determine if the $\delta^{2} \mathrm{H}, \delta^{13} \mathrm{C}$, and $\delta^{15} \mathrm{~N}$ feather isotope values of the PSFL sampled at CCFS were normally distributed, a Shapiro-Wilk test of multivariate normality was applied. The Shapiro-Wilk test of 
multivariate normality was applied using the "mshapiro.test" function of the “RVAideMemoire" package in RStudio (Hervé, 2016). The $\delta^{2} \mathrm{H}, \delta^{13} \mathrm{C}$, and $\delta^{15} \mathrm{~N}$ feather isotope values were then examined for multivariate outliers using the robust Mahalanobis distance. The robust Mahalanobis, versus the classical Mahalanobis distance was used because the data was not normally distrubted. Similar studies (Reudink et al., 2015) used the same method to isolate and remove multivariate outliers prior to running cluster analyses. The robust Mahalanobis distance was examined using the "Moutlier" function of the "chemometrics" package in RStudio (Filzmoser \& Varmuza, 2016).

To execute the Cluster analysis, the "NbClust" package (Charrad et al., 2015) in RStudio was used. Many cluster analysis packages are available in RStudio, but the "NbClust" package was chosen because it provides the most comprehensive interpretation of the data. NbClust runs 30 validity indices of which each use unique criteria to determine how many clusters are present within the data set, and provide the user with a conclusion for the best number of clusters to use based on the majority results of the validity indices (Charrad et al., 2015). Each validity index uses a different methodology to measure similarities and dissimilarities between variables, and is described in detail in (Charrad et al., 2015).

Within the NbClust package, two of several approaches to Cluster analysis are available; K-means clustering and hierarchical agglomerative clustering. Both procedures were employed to further support the selection of cluster groups. K-means clustering creates preliminary cluster groups based on the user-defined minimum/maximum, and 
then using the criteria of the validity indexes, the cluster groups are continually refined until the result is uniform (Charrad et al., 2015; Quinn \& Keough, 2002).

Hierarchical agglomerative clustering begins by analyzing the data on the individual observation level and subsequently organizes individuals into clusters that are joined with other individuals based on dissimilarity measurements (Charrad et al., 2015; Quinn \& Keough, 2002). Both the K-means cluster and hierarchical agglomerative analyses were executed in RStudio with the default parameters for the dissimilarity matrix ("NULL") and distance ("euclidean"). The euclidean distance is the square distance between two vectors (Charrad et al., 2015). For both analyses the mimimal number of clusters were set to 2 , and the maximum number of clusters were set to 10 . For both analyses all validity indices except GAP, Gamma, Gplus, and Tau were selected be calculated.

Because the K-means clustering and hierarchical agglomerative clustering procedures of the NbClust package are restricted to setting the minimal number of clusters to two, I wanted to investigate the possibility of there being a single cluster in the data. To do this, I used the "mclustBIC" function of the "mclust" package (Fraley et al., 2016) in RStudio. This procedure uses a Gaussian mixture model-based hierarchical clustering method which follows an expectation-maximazation (EM) algorithm that determines the optimal number of clusters based on the Bayesian Information Criterion (BIC) (Fraley et al., 2016). Similar studies (Reudink et al., 2015) have used the same procedure. I used the default specification of 1-9 clusters to be evaluated. 
To confirm that there were significant differences in the $\delta^{2} \mathrm{H}, \delta^{13} \mathrm{C}$, and $\delta^{15} \mathrm{~N}$ feather values of the identified cluster groups, I ran a multivariate analysis of variance (MANOVA) test. This test was performed in RStudio using the "man.mod" function.

Morphological measurement analysis (Q4). To test for relationships between morphological measurements and feather hydrogen isotope values $\left(\delta^{2} \mathrm{H}\right)$, feather carbon isotope values $\left(\delta^{13} \mathrm{C}\right)$, and feather nitrogen isotope values $\left(\delta^{15} \mathrm{~N}\right)$ of the Pacific-slope flycatchers, Canonical Correlation Analysis (CCA) was performed. Data was separated into a set of independent variables (the feather isotope values), and a set of dependent variables (the morphological measurements). The morphological measurements obtained from each PSFL that were selected for this analysis were weight, bill length, bill width, wing length, tail length, fat score, skull ossification, and primary feather wear. All variables used in this analysis were continuous.

Prior to conducting the Canonical Correlation Analysis, all variables were standardized, and a Shapiro-Wilk test of multivariate normality was applied to determine if the variables were normally distributed. The Shapiro-Wilk test of multivariate normality was applied using the "mshapiro.test" function of the "RVAideMemoire" package in RStudio (Hervé, 2016).

The following analyses were conducted in IBM SPSS 2012. Descriptive statistics were applied to determine which variables, if any, were skewed. Data was transformed using the $\mathrm{LN}$ function to compute the natural log of the skewed variables. Pearson Product-moment correlations were used to confirm that all variables within their given 
data set (feather isotope values or morphological measurements) were independent from one another $(r \geq|0.700|)$.

The null hypothesis for canonical variate selection was accepted at a significance level of $p<0.05$. Final interpretation was based upon the root score calculations of the unstandardized canonical coefficient values that corresponded with the variables with canonical loadings $(\geq|0.300|)$.

\section{Limitations}

Potential limitations of this study are rooted in our study design and applied stable isotope analysis methodologies.

Although the sample size for this study (169 individual Pacific-slope flycatchers) was sufficient, results could have potentially improved with an expansion of stopover study sites throughout the western states to incorporate multiple angles of the Pacific Flyway and to increase chances of sampling after hatching-year birds. Because this study investigated the migratory origins of solely hatching-year birds, the results may not be fully reflective of Pacific-slope flycatcher populations. The sampling of after hatchingyear birds would improve abilities to draw conclusions about expanded dynamics of Pacific-slope flycatcher populations. Because the fall capture rates of after hatching-year Pacific-slope flycatchers are significantly lower than those of hatching-year birds, obtaining a proper sample size of after hatching-year birds at the Coyote Creek Field Station would not be possible. The expansion of sampling locations would not have been feasible for this project. The collection of Pacific-slope flycatcher morphological measurements for this study were part of the standard procedures implemented by the 
Coyote Creek Field Station for Bird Banding Laboratory use. My intention of analyzing this data was to make basic inferences on potential relationships between morphological measurements and stable isotope data, but because measurements were collected under a previously established protocol the parameters that were available for analysis hold limited biological significance. Some studies that have made successful inferences from morphological measurements and isotope analysis incorporated parameters such as tarsus length, keel length and wing span to calculate body size (Arizaga et al., 2014; Bensch et al., 2009; Kempster et al., 2007; Møller \& Hobson, 2004). Statistical analyses may not have been so limited with the collection of additional morphological measurements, but given the sensitivity of Pacific-slope flycatchers during the banding process the collection of additional parameters was not feasible.

It is within the nature of stable isotopes to undergo isotopic discrimination during biological processes that are involved with assimilation by different trophic organisms, which subsequently increases chances of error, or variation in values, during investigations. Major potential sources of error fall within the naturally occurring environmental influences on stable isotope $\left(\delta^{2} \mathrm{H}, \delta^{13} \mathrm{C}\right.$ and $\left.\delta^{15} \mathrm{~N}\right)$ values. The analysis of $\delta^{2} \mathrm{H}$ in feather values contains many environmental influences such as altitude, oceanic distances, and rainfall amount which can lead to misintepreations of $\delta^{2} \mathrm{H}$ values (Kendall et al., 1995; Marshall et al., 2007; Plummer et al., 1993). Additionally, the ranges of $\delta^{2} \mathrm{H}$ values in growing-season and mean annual precipitation maps overlap multiple regions, reducing the ability to rely on stable isotope analysis alone (Bowen et al., 2005; Hobson et al., 2014; Paxton, Yau, Moore, \& Irwin, 2013). Researchers have been sucessful in 
improving geographic assignments by pairing additional data with $\delta^{2} \mathrm{H}$ analyses such as feathers of known origin (Hobson et al., 2015), band-recovery data (Sullins et al., 2016), genetic data (Paxton et al., 2013; Ruegg et al., 2014), vegetation cover data (Hobson et al., 2013), geolocaters (Solovyeva et al., 2015), and much more; all of which were not feasible for this study.

As with analysis of $\delta^{2} \mathrm{H}, \delta^{13} \mathrm{C}$ and $\delta^{15} \mathrm{~N}$ values vary with environmental factors such as microhabitat or diet selections amongst individuals for $\delta^{13} \mathrm{C}$ (Inger \& Bearhop, 2008; Marshall et al., 2007; Reudink et al., 2015) and trophic diet or agricultural influences for $\delta^{15} \mathrm{~N}$ (Inger \& Bearhop, 2008). Unlike with $\delta^{2} \mathrm{H}$, where growing-season and mean annual global maps for deuterium in precipitation are made readily available for assignment analyses by Bowen et al. (2005), maps of regional-scale $\delta^{13} \mathrm{C}$ in vegetation have not been produced for the northwestern United States and Canada. Without a strong basis of known-vegetation sample comparison, abilities to interpret Pacific-slope flycatcher prior habitat use is very limited. Additionally, analysis of $\delta^{15} \mathrm{~N}$ values are limited in providing information that hasn't already been provided by $\delta^{2} \mathrm{H}$ and $\delta^{13} \mathrm{C}$ data. Like with $\delta^{13} \mathrm{C}$, there are no readily available datasets of geographic variation in $\delta^{15} \mathrm{~N}$ values (which would likely be created from trophic organisms such as insects or prey species) upon which findings can be based. Even if known-origin $\delta^{15} \mathrm{~N}$ in the food chain existed, a sample's proximity to agricultural soils could severely skew results. Furthermore, such knownorigin $\delta^{13} \mathrm{C}$ vegetation and $\delta^{15} \mathrm{~N}$ insect samples could only be used for comparison based on species specific individual diet selection. 
An additional source of error in reported $\delta^{2} \mathrm{H}, \delta^{13} \mathrm{C}$ and $\delta^{15} \mathrm{~N}$ values could potentially be caused by laboratory preparation procedures and analytical measurement error. The cleaning of the feather samples was employed to reduce potential variation in stable isotope values from surface oil contaminants, but there is always a chance that recontamination occurred during encapsulation procedures. Laboratory surfaces, encapsulation tools, and instruments were cleaned with methanol in between each sample to avoid contamination risk, but there is no way of determining if user-based contamination occurred. Sample stable isotope values are reported as expected (mean) values through analytical measurements using continuous flow isotope ratio mass spectrometry (Wunder \& Norris, 2008). Variation in stable isotope values from analytical measurement error could potentially contribute to misinterpretation of results for this study.

Variation in $\delta^{2} \mathrm{H}$ feather stable isotope values that could have potentially been caused by environmental factors, sample preparation error, and analytical measurement error were accounted for by calibrating the amount-weighted growing season $\delta^{2} \mathrm{H}$ in precipiation of North America raster from (Bowen et al., 2005) with the published equation for Neotropical migrant non-ground foraging songbirds from (Hobson et al., 2012).

Although these limitations can cause variances in results, they do not negate this study's ability to collect preliminary information on the breeding origins and habitat selection of groups of HY Pacific-slope flycatchers migrating through the Coyote Creek Field Station at different times during the fall. The study design, data collection and 
analytical methodologies applied in this study are appropriate and sufficient for meeting our objective of obtaining basic inferences, not confident conclusions, about the probable geographic origins of migrating HY Pacific-slope flycatchers. 


\section{Results}

\section{Probable Breeding Origins of Pacific-slope flycatchers at CCFS during Fall Migration}

Precision in hydrogen analysis. Imprecision in the $\delta^{2} \mathrm{H}$ analysis was significantly greater than $3 \%$ for 4 out of the 18 duplicate samples. Four hydrogen samples were omitted due to handling error at the UC Davis Stable Isotope Facility (samples were either swapped or analyzed together). The following analyses were based on a total of 169 hatching-year Pacific-slope flycatcher individuals captured at the Coyote Creek Field Station in Milpitas, California during the fall migration of 2014.

The range of $\delta^{2} \mathrm{H}$ values for all individuals was between $-38 \%$ to $-141 \%$, which indicates that the HY Pacific-slope flycatchers sampled at the Coyote Creek Field Station in Milpitas, California represented a wide geographic range of breeding grounds (Figure 9). 


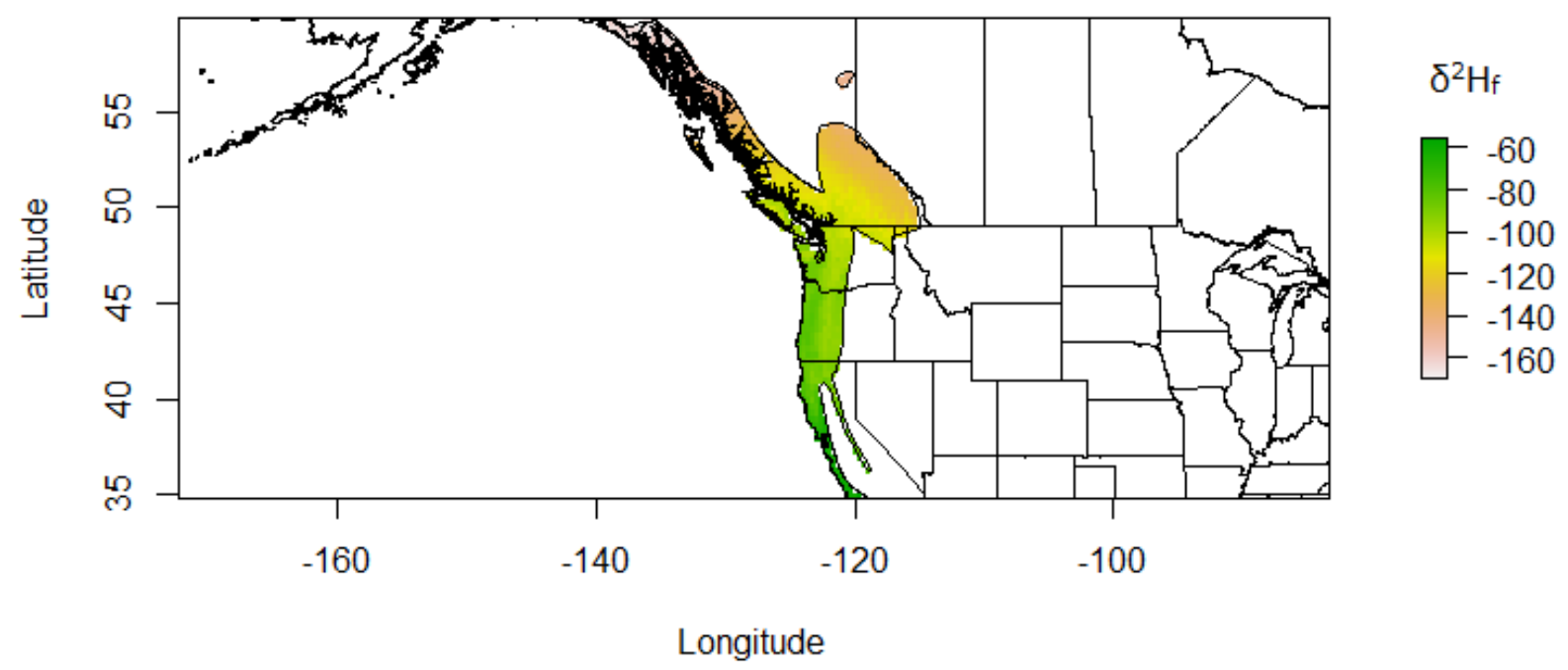

Figure 9. The final "feather isoscape" of predicted hydrogen isotope values of feathers $\left(\delta^{2} \mathrm{H}\right)$ upon which PSFL assignments were made, derived from the amount-weighted growing season $\delta^{2} \mathrm{H}$ in precipitation of North American isoscape with permission from Bowen et al. (2005), calibrated using the equation for Neotropical migrant non-ground foraging songbirds with permission from Hobson et al. (2012), and restricted to the Pacific-slope flycatcher distribution range with permission from BirdLife International and NatureServe (2015). 
The mean and standard deviation of the feather $\delta^{2} \mathrm{H}$ values were $-87.6 \pm 19.8 \%$. The values of the HY PSFL $\delta^{2} \mathrm{H}$ were normally distributed (Shapiro-Wilk normality test, $W=$ 0.99, $P=0.3$ ), and the distribution was likely bi-modal (Figure 10). All null hypothesis were accepted at a significance level of $\mathrm{p}>0.05$.

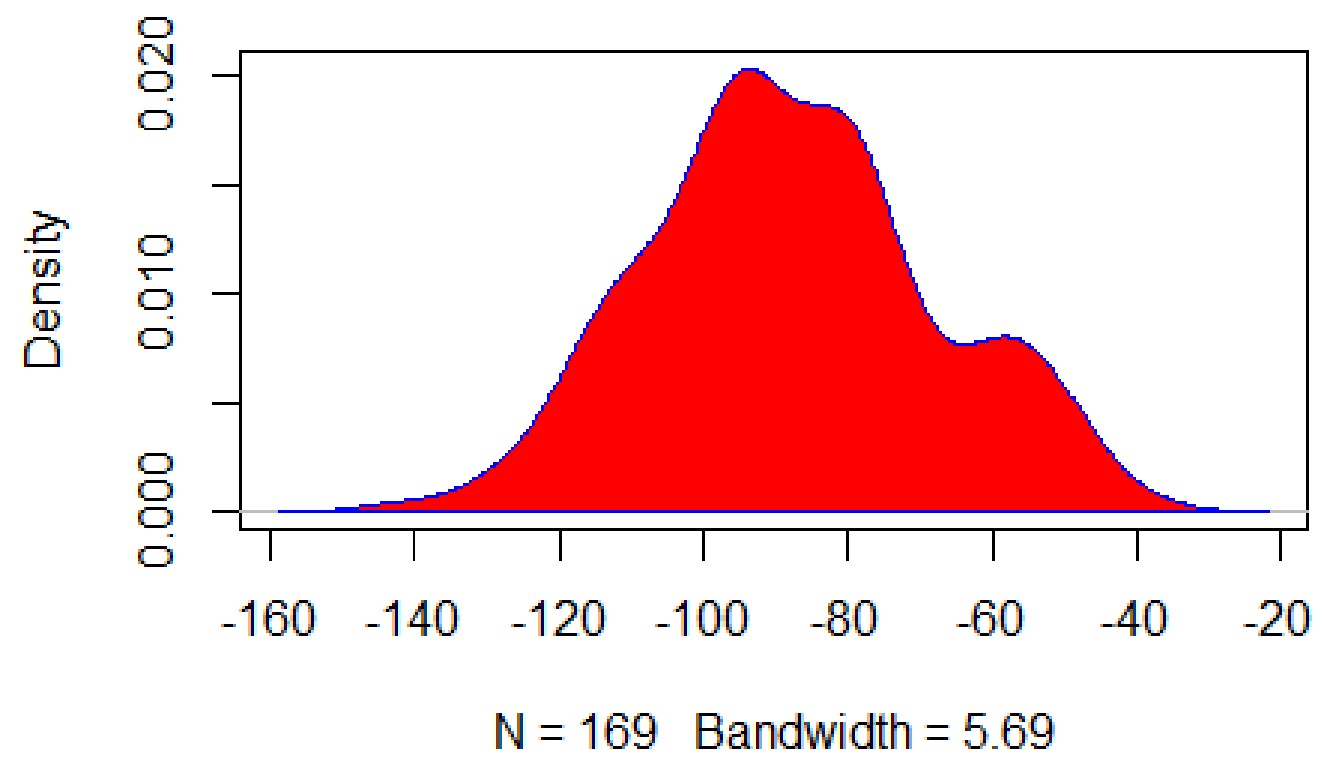

Figure 10. Kernal Density estimate of HY PSFL ( $n=169)$.

The breeding origins of the sampled PSFL likely originated from the central and southern most regions of the known Pacific-slope flycatcher breeding range. The spatially explicit likelihood-based assignment model indicated that the most likely breeding origins for the majority of the birds were equally associated with latitudinal regions with expected $\delta^{2} \mathrm{H}$ ranges of $-76 \%$ to $-97 \%$ in northwestern California, throughout western Oregon, and southern/mid-western Washington (Figure 11). 


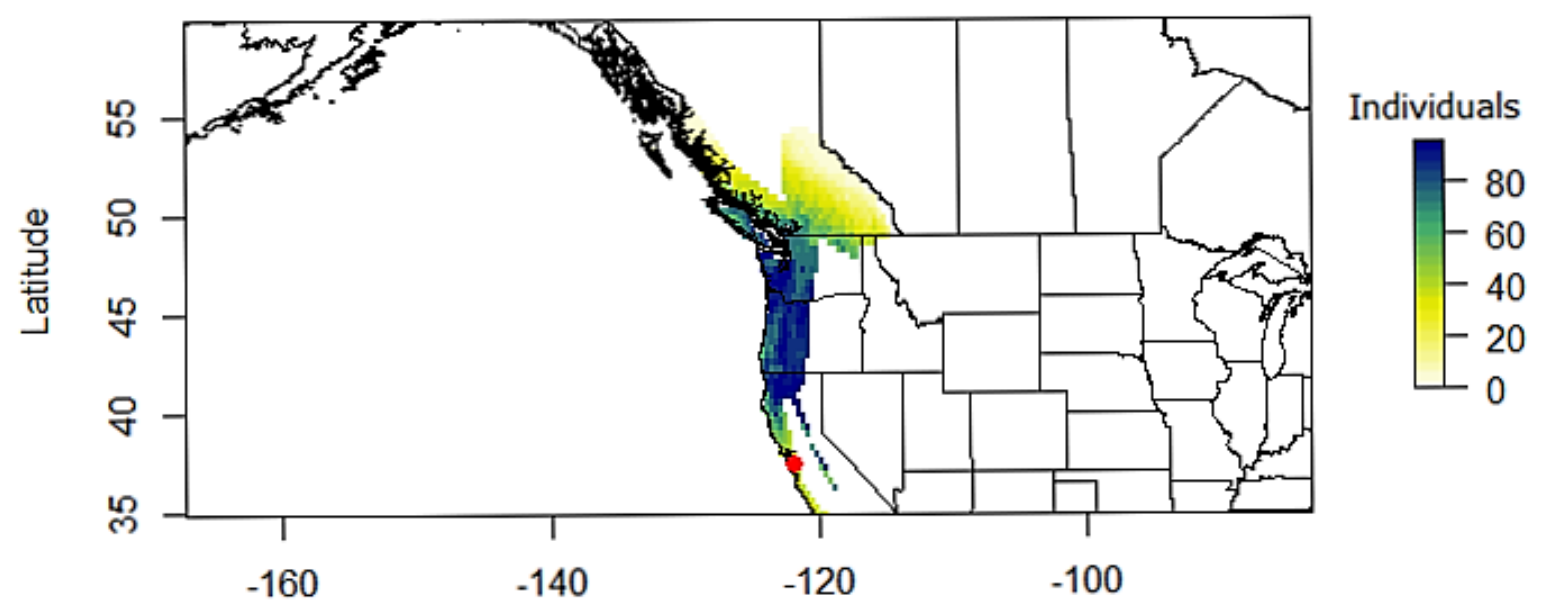

Longitude

Figure 11. Probable breeding origins of Pacific-slope flycatchers $(n=169)$ sampled at the Coyote Creek Field Station in Milpitas, California (red dot) during fall migration in 2014. The legend scale specifies the number of individual PSFL $(n=96)$ that had consistent isotopic feather values with pixels on the map of the same color based on the likelihoodbased assignment at 2:1 odds.

Ninety-six of the 169 PSFL (57\%) most likely originated from these regions.

Secondary assignments were associated with latitudinal regions with expected $\delta^{2} \mathrm{H}$ ranges of $-98 \%$ o to $-119 \%$, which included the northernmost regions of Washington and the southern border of British Columbia. There were no assignments associated with the northernmost portion of the PSFL breeding range, north of the Vancouver islands.

Relative Abundance. The incorporation of the North American Breeding Bird Survey Relative Abundance data as a prior probability surface assigned 162 out of 169 observations (individual birds) to origins throughout the entire PSFL breeding range. The model concluded that the most-likely breeding origins for this sample were from latitudinal regions with expected $\delta^{2} \mathrm{H}$ ranges of $-50 \%$ to $-97 \%$ in centralnorth/northwestern California, throughout western Oregon, and southern/mid-western 
Washington. Secondary assignments were associated with latitudinal regions with expected $\delta^{2} \mathrm{H}$ ranges of $-98 \%$ to $-141 \%$, the northernmost regions of Washington, and throughout western British Columbia (Figure 12).

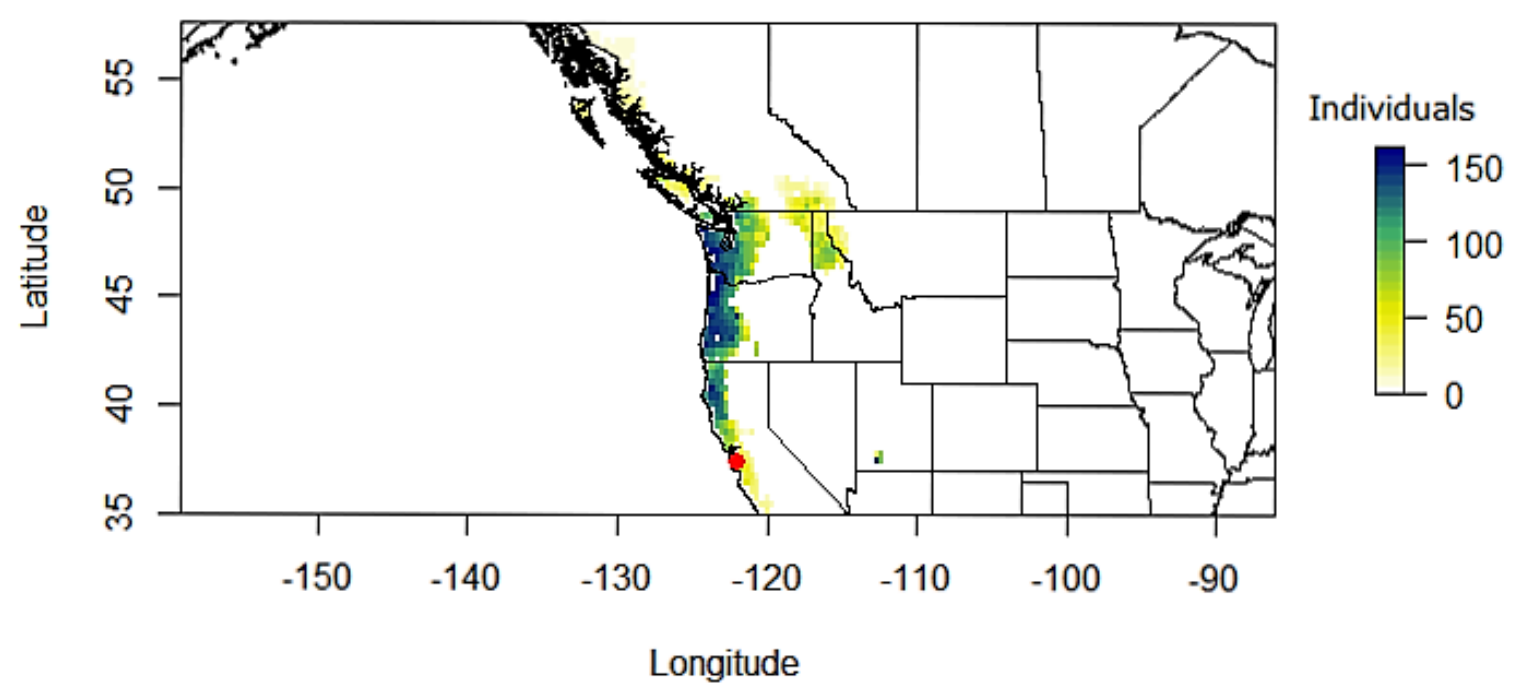

Figure 12. Probable breeding origins of Pacific-slope flycatchers $(n=169)$ sampled at the Coyote Creek Field Station in Milpitas, California (red dot) during fall migration in 2014. The legend scale specifies the number of individual PSFL $(n=162)$ that had consistent isotopic feather values with pixels on the map of the same color based on the likelihoodbased assignment at 2:1 odds incorporating North American Breeding Bird Survey Relative Abundance data within pixels as a prior probability.

Timing of migration. A significant relationship between $\delta^{2} \mathrm{H}$ and capture date at CCFS was found $\left(R^{2}=0.19, p<<0.001\right)$, which explains some of the variation of $\delta^{2} \mathrm{H}$ of PSFL tail feathers. There was a negative correlation between $\delta^{2} \mathrm{H}$ (representing latitudinal origin) and capture date at the Coyote Creek Field Station (Figure 13). PSFL migrating from more southern regions tended to arrive earlier in the season, and PSFL migrating from more norther regions tended to arrive later in the season. 


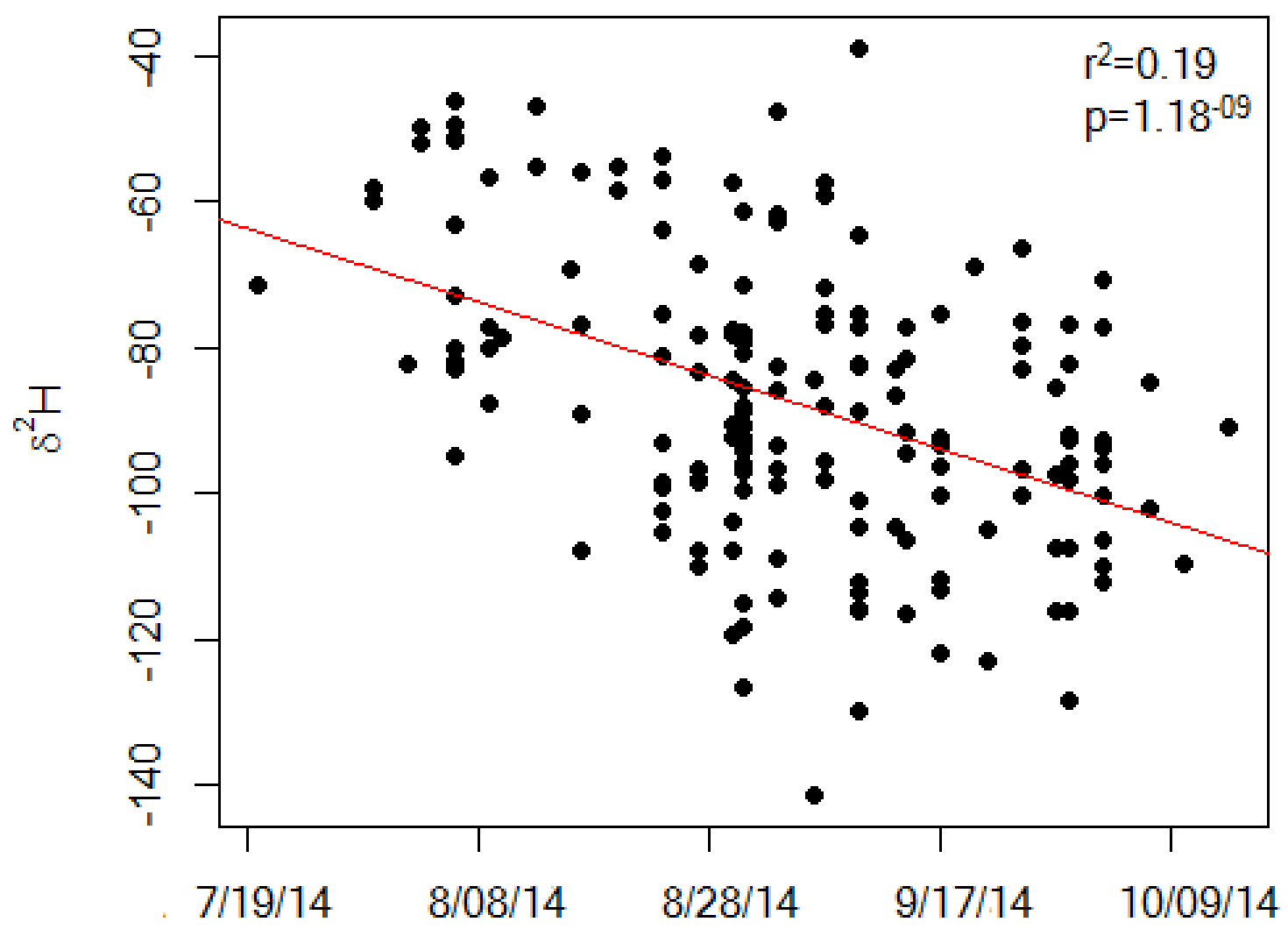

Capture Date

Figure 13. Relationship between $\delta^{2} \mathrm{H}$ and Capture Date of PSFL $(n=169)$ sampled at the Coyote Creek Field Station in Milpitas, California during fall migration in 2014.

A significant relationship between $\delta^{2} \mathrm{H}$ and capture date at CCFS was found for birds that arrived within the first half of the season $\left(R^{2}=0.24, p<<0.001\right)$, but not for birds that arrived within the second half of the season $\left(R^{2}=0.02, p=0.07\right)$. The $\delta^{2} \mathrm{H}$ values from feathers of HY PSFL migrating through the Coyote Creek Field Station in the first half of the season were on average $(\sim 15.2 \%)$ lower than birds migrating through the Coyote Creek Field Station later in the season. No significant relationships between $\delta^{2} \mathrm{H}$ 
and capture date at CCFS were found for any of the 13 weekly sub groups $(p>0.05)$. The average shift in $\delta^{2} \mathrm{H}$ per mil was $-2.945 \pm 0.494 \%$ per week (Table 1 ).

Table 1.

Average Values of $\delta^{2} H(\%)$ of 169 HY Pacific-Slope Flycatchers Sampled at the Coyote Creek Field Station in Milpitas, California During Fall of 2014.

\begin{tabular}{lrcccc}
\hline Week of capture & \multicolumn{1}{c}{$n$} & Mean & Range & SD & SE \\
\hline $7 / 20-7 / 26$ & 1 & -71.5 & -71.5 & -- & -- \\
$7 / 27-8 / 2$ & 3 & -66.7 & -57.9 to -82.2 & 13.4 & 7.7 \\
$8 / 3-8 / 9$ & 17 & -68.0 & -46.1 to -94.7 & 16.1 & 3.9 \\
$8 / 10-8 / 16$ & 4 & -62.5 & -46.8 to -78.4 & 14.1 & 7.1 \\
$8 / 17-8 / 23$ & 6 & -73.9 & -55.1 to -107.9 & 21.5 & 8.7 \\
$8 / 24-8 / 30$ & 27 & -88.2 & -53.6 to -119.5 & 17.7 & 3.4 \\
$8 / 31-9 / 6$ & 33 & -90.9 & -47.6 to -141.4 & 19.2 & 3.3 \\
$9 / 7-9 / 13$ & 25 & -87.9 & -38.8 to -129.8 & 21.5 & 4.3 \\
$9 / 14-9 / 20$ & 17 & -95.8 & -69.1 to -121.7 & 14.8 & 3.6 \\
$9 / 21-9 / 27$ & 12 & -94.7 & -66.5 to -123.1 & 16.9 & 4.8 \\
$9 / 28-10 / 4$ & 20 & -97.9 & -70.7 to -128.4 & 14.7 & 3.2 \\
$10 / 5-10 / 11$ & 3 & -98.8 & -84.7 to -109.7 & 12.8 & 7.3 \\
$10 / 12-10 / 18$ & 1 & -90.8 & -90.8 & -- & -- \\
\hline
\end{tabular}

The spatially explicit likelihood-based assignment model assigned 29 out of the 58 birds that migrated through CCFS during the first half of the season, from 7/20/14 to $8 / 30 / 14$, to latitudinal regions with expected $\delta^{2} \mathrm{H}$ ranges of $-76 \%$ to $-97 \%$ in northwestern California, throughout western Oregon, and southern/mid-western Washington (Figure 14). 


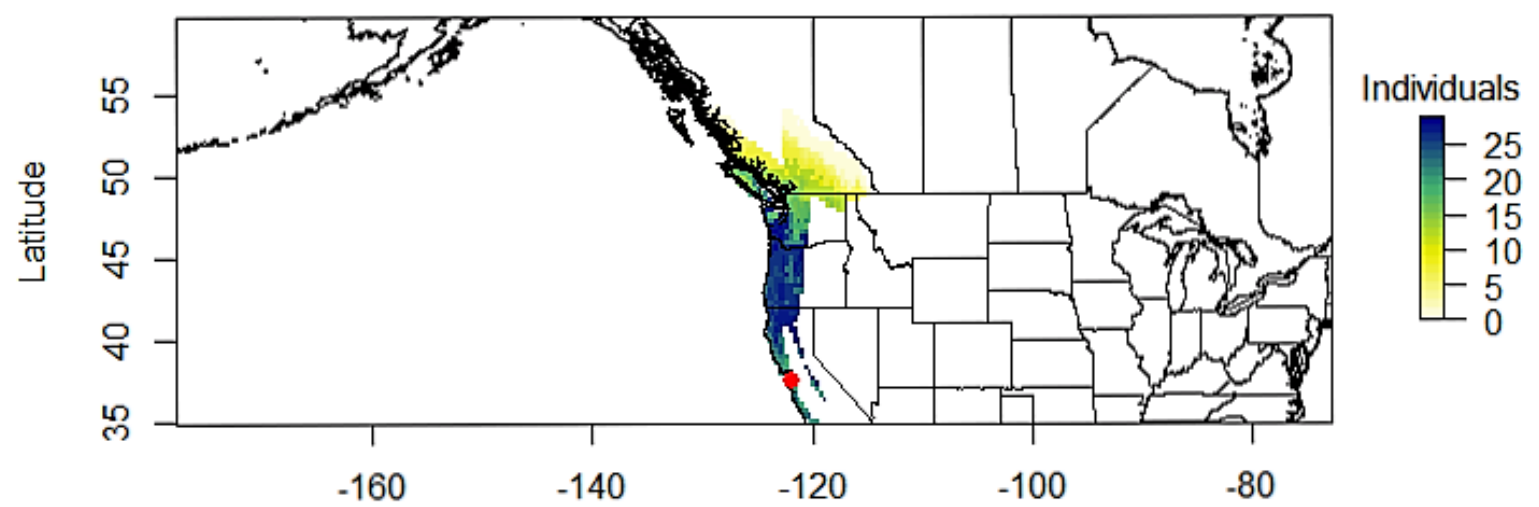

Longitude

Figure 14. Probable breeding origins of Pacific-slope flycatchers $(n=58)$ sampled at the Coyote Creek Field Station in Milpitas, California (red dot) from 7/20/2014 to 8/30/2014. The legend scale specifies the number of individual PSFL $(n=29)$ that had consistent isotopic feather values with pixels on the map of the same color based on the likelihoodbased assignment at 2:1 odds.

Secondary assignments were associated with latitudinal regions with expected $\delta^{2} \mathrm{H}$ ranges of $-98 \%$ o to $-119 \%$; the northernmost regions of Washington and the southern border of British Columbia. There were no assignments associated with the northernmost portion of the PSFL breeding range, north of the Vancouver islands.

Of the 111 birds that migrated through CCFS during the second half of the season, from $8 / 31 / 14$ to $10 / 12 / 2014$, 68 individuals were assigned to latitudinal regions with expected $\delta^{2} \mathrm{H}$ ranges of $-76 \%$ to $-115 \%$ in northwestern California, throughout western Oregon, and throughout western Washington (Figure 15). 


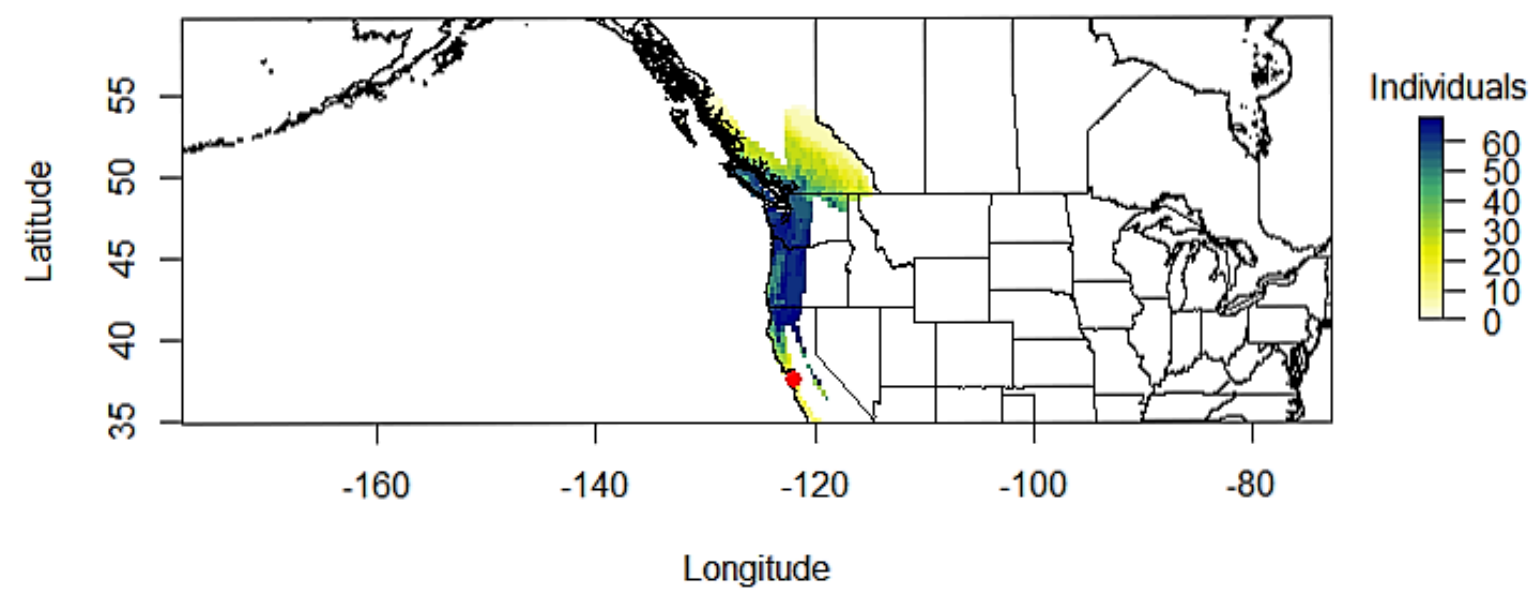

Figure 15. Probable breeding origins of Pacific-slope flycatchers $(n=111)$ sampled at the Coyote Creek Field Station in Milpitas, California (red dot) from 8/31/2014 to $10 / 12 / 2014$. The legend scale specifies the number of individual PSFL $(n=68)$ that had consistent isotopic feather values with pixels on the map of the same color based on the likelihood-based assignment at 2:1 odds.

Secondary assignments were associated with latitudinal regions with expected $\delta^{2} \mathrm{H}$ ranges of $-98 \%$ to $-119 \%$; the northernmost regions of Washington and the southern border of British Columbia. There were no assignments associated with the northernmost portion of the PSFL breeding range, north of the Vancouver islands.

Spatially explicit assignments varied when the samples (individual birds) were separated by week of capture, with birds arriving earlier in the season being assigned to latitudinal regions with expected $\delta^{2} \mathrm{H}$ ranges of $-32 \%$ to $-96 \%$ in northwestern California and throughout western Oregon, and birds that arrived later in the season being assigned to latitudinal regions with expected $\delta^{2} \mathrm{H}$ ranges of $-94 \%$ to $-119 \%$ in northern Washington and the southern border of British Columbia (Appendix B and Figure 16). 


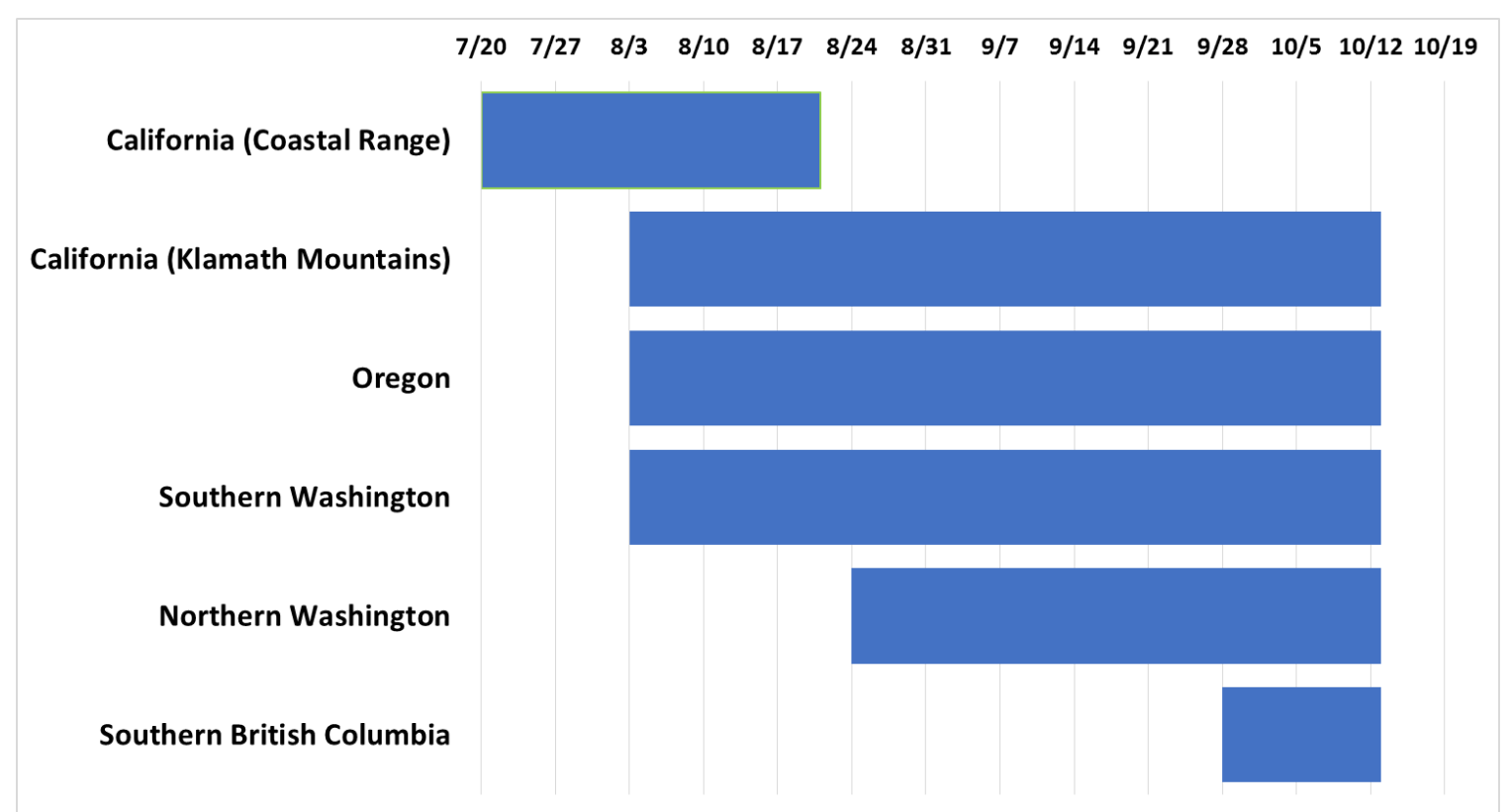

Figure 16. Timeline of Pacific-slope flycatchers migrating from varying probable breeding origins through the Coyote Creek Field Station in Milpitas, California in fall of 2014.

Birds that were assigned to latitudinal regions with expected $\delta^{2} \mathrm{H}$ ranges of $-54 \%$ to $-75 \%$, the San Francisco Bay Area west of the Sierra Nevada Mountain Range, were captured at CCFS only between 7/20/14 and 8/23/14. Birds that were assigned to latitudinal regions with expected $\delta^{2} \mathrm{H}$ ranges of $-76 \%$ to $-97 \%$, northwestern California, western Oregon, and southwestern Washington, were captured at CCFS only between $8 / 3 / 14$ and 10/12/2014. Birds that were assigned to latitudinal regions with expected $\delta^{2} \mathrm{H}$ ranges of $-98 \%$ to $-119 \%$, northwestern Washington and southern British Columbia; were captured at CCFS only between 8/24/14 and 10/13/14. 


\section{Natal Origin Habitat Selection of Pacific-slope flycatchers at CCFS during Fall Migration}

Precision in carbon and nitrogen analysis. Imprecision in the $\delta^{13} \mathrm{C}$ analysis was significantly greater than $0.2 \%$ for 8 out of the 14 duplicate samples, and significantly greater than $0.3 \%$ for 7 out of the 14 duplicate samples for $\delta^{15} \mathrm{~N}$ analysis.

All three $\left(\delta^{2} \mathrm{H}, \delta^{13} \mathrm{C}\right.$, and $\left.\delta^{15} \mathrm{~N}\right)$ stable isotope feather values were accessible from 167 HY PSFL (Appendix C). The mean (and standard deviation) isotope values for $\delta^{2} \mathrm{H}$ were $-87.5 \pm 19.8 \%$ \%,$-23.1 \pm 0.9 \%$ for $\delta^{13} \mathrm{C}$, and $5.5 \pm 1.5 \%$ for $\delta^{15} \mathrm{~N}$. Significant relationships were found among all three stable isotopes: $\delta^{2} \mathrm{H}$ and $\delta^{13} \mathrm{C}\left(R^{2}=0.14, p<<\right.$ $0.001), \delta^{2} \mathrm{H}$ and $\delta^{15} \mathrm{~N}\left(R^{2}=0.10, p<<0.001\right), \delta^{13} \mathrm{C}$ and $\delta^{15} \mathrm{~N}\left(R^{2}=0.07, p \leq 0.001\right)$. The feather isotope values of $\delta^{2} \mathrm{H}, \delta^{13} \mathrm{C}$, and $\delta^{15} \mathrm{~N}$ were not multivariate normally distributed (Shapiro-Wilk test of multivariate normality, $W=0.91, p<0.001$ ). All null hypotheses were accepted at a significance level of $p>0.05$. The robust Mahalanobis distance operation detected 12 multivariate outliers. These outliers were removed from the dataset, leaving 155 observations to analyze.

The $k$-means cluster analysis concluded that 2 clusters were the best number of clusters based on the majority (10 out of $30,33 \%$ ) of the validity indices. Against the majority were 4 indices (13\%) proposing 3 clusters as the best number, and 3 indices (10\%) proposing 10 clusters as the best number. The results were similar after removing the 12 multivariate outliers; the majority ( 9 out of 30,30\%) proposed 2 as the best number of clusters. This was followed by 8 indices (26\%) proposing 4 clusters and 3 indices (10\%) proposing 8 clusters as the best number. 
The hierarchical agglomerative cluster analysis showed that 2 clusters were the best number based on the majority (10 out of 30,33\%) of the validity indices. The second and third ranks were 6 indices (20\%) proposing 4 clusters, and 4 indices (13\%) proposing 10 clusters. Alternatively, after removing outliers, the majority ( 8 out of $30,26 \%$ ) of the validity indices for the hierarchical agglomerative method proposed 4 as the optimal number of clusters, but this was followed closely by 7 indices (23\%) proposing the use of 2 clusters. 5 indices $(16 \%)$ proposed that 3 clusters were the best number.

The model-based hierarchical cluster analysis resulted in all 3 of the top models (VII, VVE, VEV) concluding that 2 was the optimal number of clusters. This conclusion is based on the highest BIC value for each model (Table 2). Alternatively, after removing outliers, 3 different top models (EEE, EEV, EVE) all concluded that 1 was the optimal cluster number (Table 3). 
Table 2.

Bayesian Information Criterion (BIC) from the Top 3 Hierarchical Clustering Models.

\begin{tabular}{lccc}
\hline & \multicolumn{3}{c}{ BIC } \\
\cline { 2 - 4 } Number of clusters & VII & VVE & VEV \\
\hline 1 & -1439.2 & -1416.1 & -1416.1 \\
2 & -1401.5 & -1402.8 & -1403.2 \\
3 & -1419.7 & -1413.9 & -1419.1 \\
4 & -1432.9 & -1447.5 & -1460.4 \\
5 & -1440.6 & -1488.1 & -1472.2 \\
6 & -1446.1 & -1489.1 & -1483.3 \\
7 & -1447.7 & -1506.5 & -1506.8 \\
8 & -1467.9 & -1516.2 & -1533.8 \\
9 & -1478.8 & -1558.6 & -1561.4 \\
\hline
\end{tabular}

Note. BIC values are shown for $1-10$ clusters for $\delta^{2} \mathrm{H}, \delta^{13} \mathrm{C}$, and $\delta^{15} \mathrm{~N}$ isotopes from feathers of 167 individual HY Pacific-slope flycatchers.

Table 3.

Bayesian Information Criterion (BIC) from the Top 3 Hierarchical Clustering Models.

\begin{tabular}{lccc}
\hline & \multicolumn{3}{c}{ BIC } \\
\cline { 2 - 4 } Number of clusters & EEE & EEV & EVE \\
\hline 1 & -1171.7 & -1171.7 & -1171.7 \\
2 & -1173.2 & -1186.1 & -1179.8 \\
3 & -1179.9 & -1199.8 & -1200.6 \\
4 & -1200.6 & -1224.3 & -1221.9 \\
5 & -1201.7 & -1242.7 & -1232.4 \\
6 & -1221.1 & -1264.1 & -1254.2 \\
7 & -1237.9 & -1290.9 & -1274.9 \\
8 & -1240.9 & -1317.2 & -1296.9 \\
9 & -1261.1 & -1338.1 & -1316.1 \\
\hline
\end{tabular}

Note. BIC values are shown for $1-10$ clusters for $\delta^{2} \mathrm{H}, \delta^{13} \mathrm{C}$, and $\delta^{15} \mathrm{~N}$ isotopes from feathers of 155 individual HY Pacific-slope flycatchers. 
These results show that there is an apparent grouping of 2 clusters amongst all 167 observations (individual birds). Because the majority of the clustering procedures detected 2 clusters, a liberal approach to keeping the multivariate outliers was taken. Slight variation in analysis selection of cluster groups is common, several other studies have also found that results may be inconsistent amongst indices (Charrad et al., 2015; Milligan \& Cooper, 1985; Reudink et al., 2015).

The results of the MANOVA confirmed that there were significant differences between the $\delta^{2} \mathrm{H}, \delta^{13} \mathrm{C}$ and $\delta^{15} \mathrm{~N}$ feather stable isotope values between the 2 cluster groups that stemmed from the $k$-means cluster analysis (MANOVA, $F=126.99, \mathrm{df}=3,163, \mathrm{p}<$ 0.001). The observations (individual birds) in the $k$-means cluster group \#1 showed, on average, lower (more negative) $\delta^{2} \mathrm{H}$, lower (more negative) $\delta^{13} \mathrm{C}$, and lower $\delta^{15} \mathrm{~N}$ values, while the observations (individual birds) in the $k$-means cluster group \#2 showed, on average, higher $\delta^{2} \mathrm{H}, \delta^{13} \mathrm{C}$, and $\delta^{15} \mathrm{~N}$ ratios (Table 4, Figure 17). 
Table 4.

Mean ( \pm SD) Stable Isotope Ratios of Feathers from 167 Individual HY Pacific-Slope Flycatchers Partitioned into 2 Clusters Based on K-Means Clustering.

\begin{tabular}{llll}
\hline Cluster no. & $\delta^{2} \mathrm{H}$ & $\delta^{13} \mathrm{C}$ & $\delta^{15} \mathrm{~N}$ \\
\hline 1 & $-99.3(13.6)$ & $-23.4(0.7)$ & $4.8(1.1)$ \\
2 & $-70.2(13.9)$ & $-22.4(0.8)$ & $6.5(1.3)$ \\
\hline
\end{tabular}

Note. Clusters correspond to those shown in Figure 17.

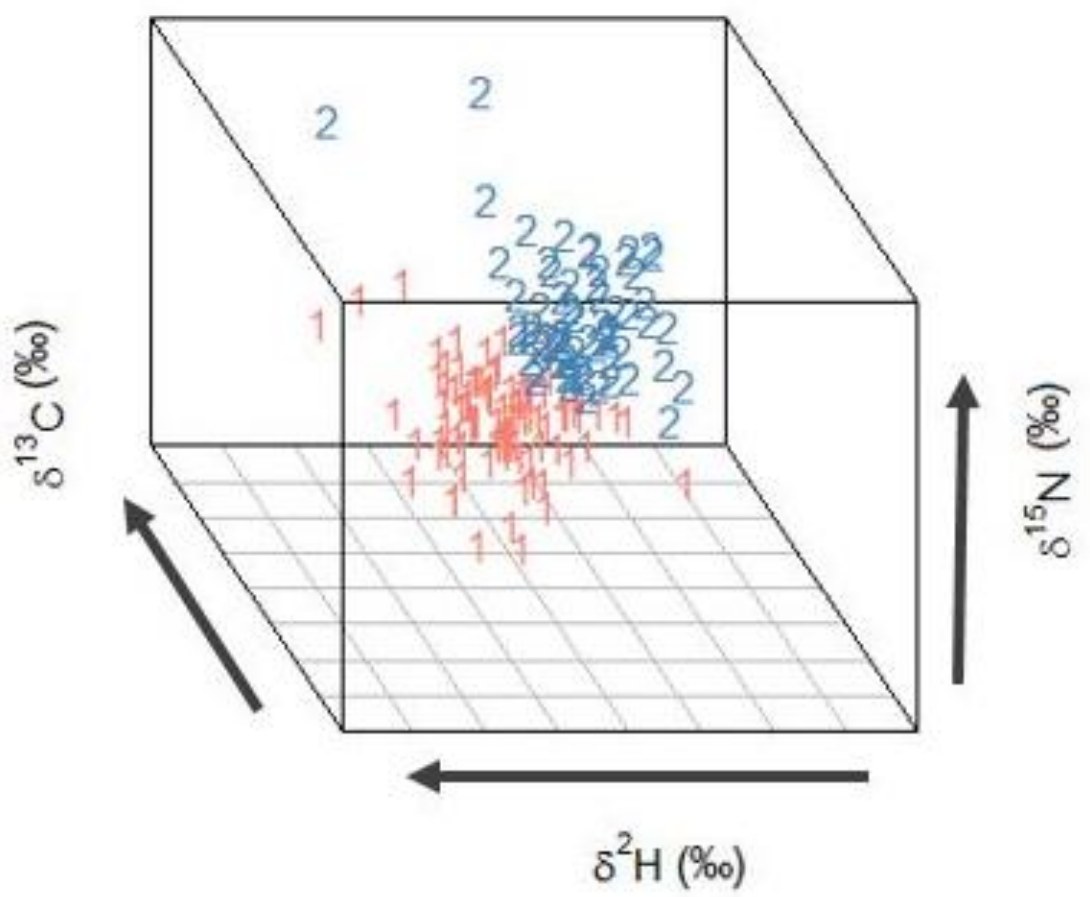

Figure 17. Clustering of stable isotope values of feathers from HY Pacific-slope flycatchers $(n=167)$ sampled at the Coyote Creek Field Station in Milpitas, California during fall migration in 2014 into 2 clusters based on $k$-means clustering. 


\section{Physical Conditions of Pacific-slope flycatchers at CCFS during Fall Migration}

All three stable isotopes $\left(\delta^{2} \mathrm{H}, \delta^{13} \mathrm{C}, \delta^{15} \mathrm{~N}\right)$ and all eight (weight, bill length, bill width, wing length, tail length, fat score, skull ossification, and primary feather wear) morphological measurements were accessible from 154 HY PSFL. The three feather stable isotopes and the eight morphological measurements were not multivariate normally distributed (Shapiro-Wilk test of multivariate normality, $W=0.69, p<0.001$ ). Weight and primary feather wear were asymmetrically distributed to the right, with a skewness of $2.6(\mathrm{SE}=0.195)$ and $1.7(\mathrm{SE}=0.195)$, respectively. Primary feather wear was removed from further analysis due to too many missing data values. All within-set variables were independently correlated (Pearson Product-moment correlations, $r<|0.700|$ ).

The Canonical Correlation Analysis returned 1 statistically significant canonical variate, Canonical Variate 1, (F-test, $p=0.041$ ). All three Canonical Loadings from Set 1 (feather isotopes values) returned values $(\geq|0.300|)$ and were selected for interpretation (Table 5). Fat score and the log of weight returned Canonical Loading values of $(\geq|0.300|)$ and were selected for interpretation (Table 6). 
Table 5.

Canonical Loadings for Stable Isotope Values of Feathers from HY Pacific-Slope Flycatchers $(n=154)$.

\begin{tabular}{lrrr}
\hline & \multicolumn{3}{c}{ Canonical Loadings } \\
\cline { 2 - 4 } Variable & 1 & 2 & 3 \\
\hline$\delta 2 H$ & -.898 & .366 & .245 \\
$\delta 13 C$ & -.763 & -.377 & -.525 \\
$\delta 15 N$ & -.490 & -.625 & .608 \\
\hline
\end{tabular}

Note. Interpretation was based on Loadings with values $(\geq|0.300|)$ for Canonical Variate 1.

Table 6.

Canonical Loadings for Morphological Measurements of HY Pacific-Slope Flycatchers $(n=154)$.

\begin{tabular}{lccr}
\hline & \multicolumn{3}{c}{ Canonical Loadings } \\
\cline { 2 - 4 } Variable & 1 & 2 & 3 \\
\hline Bill Length & -.269 & .591 & -.071 \\
Bill Width & .210 & .040 & -.602 \\
Wing Length & .133 & .227 & -.808 \\
Tail Length & -.139 & .118 & -.531 \\
Fat Score & .619 & -.059 & .298 \\
Skull & -.053 & -.733 & .096 \\
Log of Weight & .878 & .265 & -.075 \\
\hline
\end{tabular}

Note. Interpretation was based on Loadings with values $(\geq|0.300|)$ for Canonical Variate 1. 
Root scores showed a significant relationship $(\mathrm{p}=0.041, \mathrm{r}=0.366)$ between the $\log$ of weight, fat score and all three feather isotope values (Figure 18).

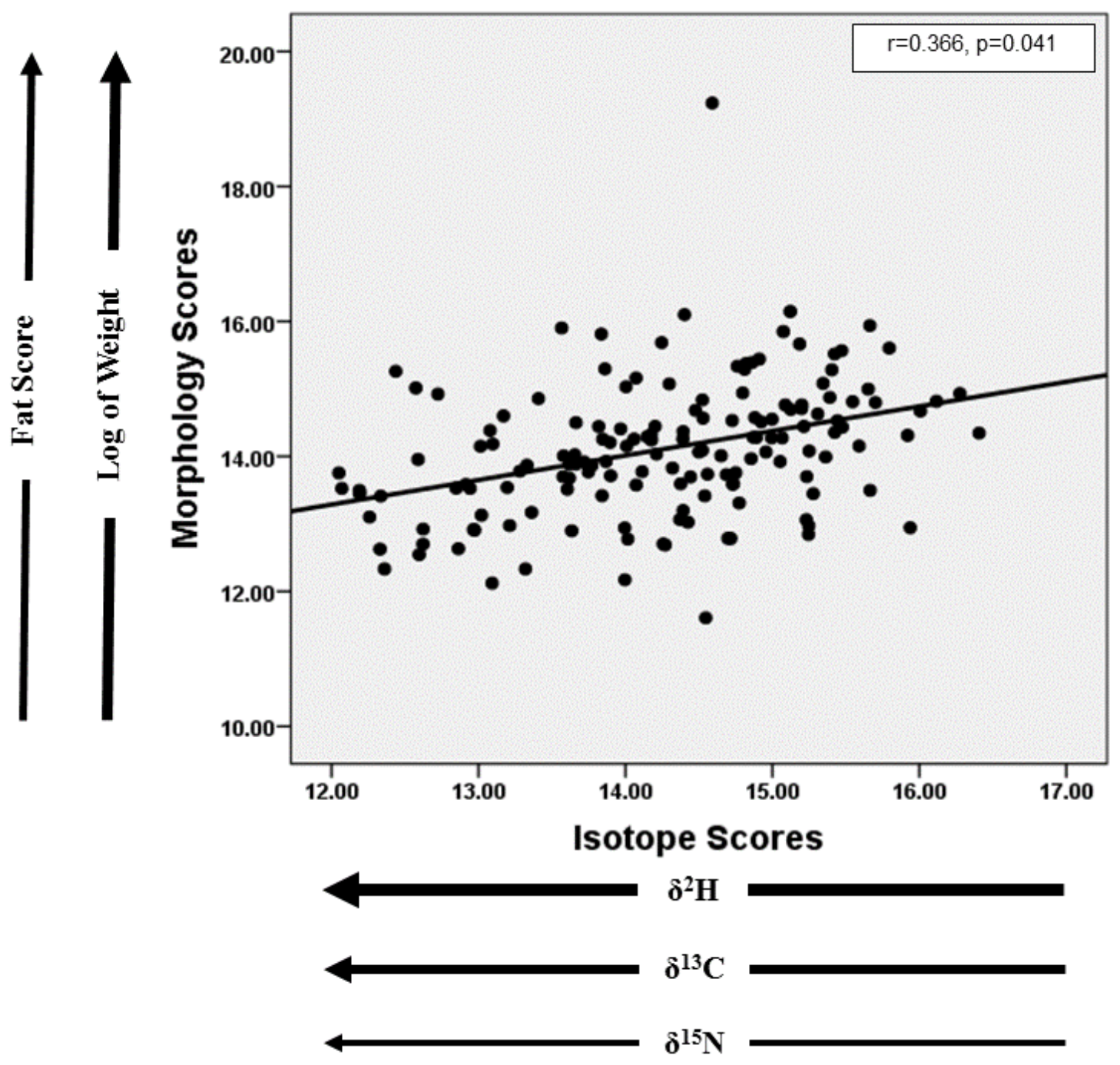

Figure 18. Relationship between loadings (Isotope Values and Morphological Measurements) of HY Pacific-slope flycatchers $(n=154)$ for Canonical Variate 1.

The Canonical Correlation Analysis demonstrated that birds with more negative $\delta^{2} \mathrm{H}$, $\delta^{13} \mathrm{C}$ and $\delta^{15} \mathrm{~N}$ values generally had lower weights (log) and fat scores. 


\section{Discussion}

This study provides the first assessment of migratory connectivity in Pacific-slope flycatchers (PSFL), a species for which no such data currently exist. The primary purpose of this research was to collect preliminary information on the breeding origins and habitat selection of groups of hatching-year (HY) Pacific-slope flycatchers migrating through the Coyote Creek Field Station in Milpitas, CA, in the South San Francisco Bay Area, at different times during the fall. This study also examined potential relationships between the morphological characteristics of HY Pacific-slope flycatchers and the inferred relative breeding origins and habitats used.

This study demonstrates that the geographic origins of HY Pacific-slope flycatchers, as inferred by stable isotope analysis and spatially explicit likelihood-based assignment models, were from a range of regions throughout their known breeding grounds and these origins varied temporally, specifically from northern California to southwestern British Columbia. Of the three approaches this study applied to deduce PSFL breeding origins, the partitioning of assignments by capture week proved to be the most informative. Some migratory connectivity studies have discussed the influence of temporal data to explain the variation of $\delta^{2} \mathrm{H}$ in feathers (González-Prieto et al., 2011; Kelly, 2006; Kelly et al., 2002), but the investigation of geographic origins of individuals using stable isotope analysis, spatially explicit likelihood-based assignment models, and timing of migration is a novel approach.

The significant relationship between between $\delta^{2} \mathrm{H}$ and capture date for PSFL justifies incorporation of temporal data for inference. Our results are consistent with other studies 
that have investigated relationships between migration timing and breeding latitude. Kelly et al. (2002) found a strong relationship between $\delta^{2} \mathrm{H}$ of feathers from Wilson's warblers (Cardellina pusilla) and arrival date during fall migration. Kelly (2006) found relationships between $\delta^{2} \mathrm{H}$ and capture date of yellow warblers (Setophaga petechia) orange-crowned warblers (Oreothlypis celata) and common yellowthroats (Geothlypis trichas).

Results for the HY PSFL caught in the south San Francisco Bay Area illustrate that birds with natal origins of more southern latitudes such as northern California, throughout western Oregon and southern Washington migrated through CCFS earlier than those from more northern latitudes such as northern Washington and southwestern British Columbia. This pattern suggests that the HY PSFL may employ chain migration strategies, in which populations migrate in an even progression (Fontaine, Stutzman, \& Gannes, 2015). Several other studies have reported similar findings of chain migration. For example, González-Prieto et al. (2011) found that HY veery (Catharus fuscescens) migrating from southern latitudes arrived at stopover sites in Colombia before birds from more northern latitudes. Kelly (2006) made the same conclusions about orange-crowned warblers and common yellowthroats during fall migration arriving at their wintering grounds in New Mexico at different times. Although this finding provides new insight on PSFL fall migration, the wintering grounds of the individual birds in this study were unknown.

The results of the geographic assignments that were partitioned by capture week (Appendix B) are consistent with the results of the group assignment (Figure 11) in that 
the majority of the birds were associated with regions spanning between northwestern California and midwestern Washington, with a secondary group associated with regions around the southwestern Canadian border. The partitioning of geographic assignments by capture week suggested that there may be distinct groups of migrant PSFL moving through the south San Francisco Bay region, with local breeders arriving the earliest (July 20- July 26, 2014), followed by breeders from northwestern California-to-midwestern Washington (August 3- August 9, 2014), breeders from northern Washington (August 24August 30, 2014), and British Columbia breeders arriving the latest (September 28 October 4). Similar patterns of migratory timing have been found in other songbird species. Paxton et al. (2013) combined stable isotopes and mitochondrial DNA to determine the weekly distribution of geographic origins of after-hatching-year Wilson's warblers migrating to stopover sites in Arizona during Spring migration. Migratory connectivity of Wilson's warblers migrating through stopover sites in Arizona were further refined in a study by Ruegg et al. (2014), which incorporated high-resolution genetic markers with the temporal data.

Inferences about natal habitats provide valuable information that can further refine the geographic origins of migratory birds and aid in the assessment of migratory connectivity.

Results for HY Pacific-slope flycatchers, as revealed by $\delta^{2} \mathrm{H}, \delta^{13} \mathrm{C}$, and $\delta^{15} \mathrm{~N}$ stable isotope feather values, suggested that individual birds clustered naturally into two isotopically distinct groups representing regional origin. Variations in $\delta^{2} \mathrm{H}, \delta^{13} \mathrm{C}$, and $\delta^{15} \mathrm{~N}$ values can be explained by a variety of environmental factors that ultimately define 
different habitat types (Reudink et al., 2015). Variation in $\delta^{2} \mathrm{H}$ values are related to latitude, altitude, distance from the ocean, and rainfall amount (Kendall et al., 1995; Marshall et al., 2007; Plummer et al., 1993). Variation in $\delta^{13} \mathrm{C}$ is related to the climatic distribution of $\mathrm{C}_{3}, \mathrm{C}_{4}$, and CAM plants (Inger \& Bearhop, 2008; Marshall et al., 2007), while variation in $\delta^{15} \mathrm{~N}$ is related to trophic diet and agricultural soil exposure (Inger \& Bearhop, 2008).

The one distinct group migrated from more northern latitudes with cooler and wetter climates than birds in the second group. Additionally, the diet of birds from the first group may have consisted of fewer insects than plants than the diets of birds from the second group, but more data on such materials would need to have been collected to properly infer this. The finding that HY Pacific-slope flycatchers originating from cooler and wetter climates than others is supported by research showing that $\delta^{13} \mathrm{C}$ values vary across differentiating habitats under temperature and moisture influences influences (Garcia-Perez \& Hobson, 2014; Hobson et al., 2012; Inger \& Bearhop, 2008; Marra et al., 1998; Marshall et al., 2007; Reudink et al., 2015). Pacific-slope flycatchers breed in coastal habitats stretching from southeastern Alaska, northwestern and central British Columbia, and the Queen Charlotte and Vancouver islands to southwestern California and throughout the mountain ranges of northern and southern Baja California (American Ornithologists' Union, 1998; Lowther, 2000). Habitats within the Pacific Coast mountain ranges are characterized by climatic-moisture scales which vary with latitude; cooler, wetter regions are found farther north (The Editors of Encyclopædia Britannica, 2006; Turner \& Kuhlmann, 2014). The HY Pacific-slope flycatchers that were characterized to 
have originated from cooler and wetter climates were also shown to originate from more northern latitudes, which further supports my findings within the spatially explicit likelihood-based assignment models.

Multi-isotope $\left(\delta^{2} \mathrm{H}, \delta^{13} \mathrm{C}\right.$ and $\left.\delta^{15} \mathrm{~N}\right)$ approaches have been previously used in studies of migratory connectivity. Reudink et al. (2015) found natural wintering ground clusters (inferred from $\delta^{2} \mathrm{H}, \delta^{13} \mathrm{C}$ and $\delta^{15} \mathrm{~N}$ claw values) within a population of Vaux's swift (Chaetura vauxi) using a stopover roost site in British Columbia. In a study conducted by Garcia-Perez \& Hobson (2014), multi-isotope clusterering, migratory connectivity indices, and probability-based assignment models yielded longitudinal links between the wintering and breeding grounds of barn swallow (Hirundo rustica) sampled on breeding sites throughout Canada and the U.S. Garcia-Perez \& Hobson's (2014) study incorporated an isoscape of vegetation cover (based on previously collected $\delta^{13} \mathrm{C}$ values from plants throughout the potential wintering range) which strenghtened their ability to make geographic assignments. Similarly, Hobson et al. (2012) constructed plant $\delta^{13} \mathrm{C}$ and $\delta^{15} \mathrm{~N}$ isoscapes of Africa and were successful making in assignments of previously published feather data to geographic clusters based on multi-isotopes. Similar to my findings, these studies have used $\delta^{13} \mathrm{C}$ and $\delta^{15} \mathrm{~N}$ feather isotope data to further refine migratory origins of birds.

This study also investigated potential relationships between morphological measurements and feather isotope values $\left(\delta^{2} \mathrm{H}, \delta^{13} \mathrm{C}\right.$ and $\left.\delta^{15} \mathrm{~N}\right)$ of the HY Pacific-slope flycatchers that migrated through CCFS in the fall of 2014. Certain morphological characteristics of birds affect energetic abilities during migration, and have the ability to 
provide information about an individual's migratory and foraging behavior (Hedenström, 2008; Nowakowski et al., 2014; Vágási et al., 2016). For example, it has been widely observed that the length of a bird's wing is positively correlated with the length of distance that the bird migrates (Delingat et al., 2011; Gunnarsson et al., 2012; Milá et al., 2008; Nowakowski et al., 2014; Pérez-Tris \& Tellería, 2003; Vágási et al., 2016). Body mass has been observed to decrease with migration distances (Jones \& Witt, 2014; Kaboli et al., 2007; Sol, Lefebvre, \& Rodríguez-Teijeiro, 2005). Fat score at stopover sites is representative of the amount of fat being stored in a birds body and has many implications for migration strategies (Lindström et al., 2002; Meissner, 1996; Meissner, 2009; Wichmann et al., 2004).

The results of the analysis between morphological measurements and the feather isotope values of the HY Pacific-slope flycatchers suggested that individual birds with less enriched $\delta^{2} \mathrm{H}, \delta^{13} \mathrm{C}$, and $\delta^{15} \mathrm{~N}$ feather isotope values will exhibit lower body masses (Log of weight) and lower fat Scores.

The findings of my study align most closesly with Arizaga, Alonso, \& Hobson's (2014) study of crossbills (Loxia spp.), in which researchers were able to isolate a migratory population moving through a stopover site based on morphological measuremeants associated with regions with distinct foraging vegetation specific to crossbill preferences. Unlike with the crossbills, there are no known obvious morphometric differences between populations of Pacific-slope flycatchers, most likely because they are not specialist foragers. In a captive-rearing study of song sparrows (Melospiza melodia), Kempster et al. (2007) concluded there were no significant 
relationships between $\delta^{13} \mathrm{C}$ and $\delta^{15} \mathrm{~N}$ values and physiological parameters of nutritional stress, but as expected body mass and fat score were found to be significantly lower in malnourished captive birds. Morphological measurements in this study may have similar implications to those of Kempster et al. (2007), in that $\delta^{13} \mathrm{C}$ and $\delta^{15} \mathrm{~N}$ feather values provide less information then $\delta^{2} \mathrm{H}$ values and that lower body masses and Fat Scores may be indicitive of a certain level of nutritional/environmental stress. The Pacific-slope flycatchers that exhibited lower body masses and fat scores likely migrated through the south San Francisco Bay from more northern breeding regions than the other birds, and we may be able to speculate that longer migration serves as a form of environmental stress that is reflected in these morphological characteristics.

Overall, I found the incorporation of temporal data with spatially explicit likelihoodbased assignment models of Pacific-slope flycatcher $\delta^{2} \mathrm{H}$ feather values proved to be the most informative in terms of determining probable geographic origins and initial assessments of migratory connectivity. The incorporation of $\delta^{13} \mathrm{C}$ and $\delta^{15} \mathrm{~N}$ feather values and morphological data within the cluster and canonical correlation analyses further supported my findings within the spatially explicit likelihood-based assignments, but were not especially informative on their own. In summary, weekly spatially explicit likelihood-based assignment models suggest that HY Pacific-slope flycatchers utilize chain-migration strategies, and migrate through the Coyote Creek Field Station in Milpitas, CA during the fall from a range of geographic origins within their known breeding grounds. The proportion of individuals migrating through CCFS from more northern breeding regions was discovered to be significantly lower than the individuals 
migrating from lower latitudes. The incorporation of $\delta^{13} \mathrm{C}$ and $\delta^{15} \mathrm{~N}$ data provided secondary information to further confirm that HY Pacific-slope flycatchers migrating through CCFS originated from multiple breeding origins. Analysis of morphological data suggested that birds that migrate through CCFS from more northern breeding latitudes (and with the incorporation of the temporal data we can speculate that these populations migrate through CCFS towards the end of fall migration) will have lower body weights and small fat scores.

Although there were limitations, and the points made in this study are basic inferences about the probable geographic origins of migrating HY Pacific-slope flycatchers, the results provided valuable initial information on the fall migration of this species. These findings can serve as a foundation for future researchers to better define the migratory patterns, breeding territories and levels of migratory connectivity of Pacific-slope flycatcher populations. This is the only known study that has investigated the migration of Pacific-slope flycatchers and shed light on chain-migration patterns of the species. The inferences made from the migratory timing data collected in this study have multiple implications for stopover ecology, environmental degradation, and methodologies in migratory connectivity. This study strongly indicates that Pacific-slope flycatchers breeding in multiple regions of western North America, that migrate hundreds of miles south to winter, rely heavily on stopover sites such as the Coyote Creek Field Station in Milpitas, CA. It is imperative that riparian corridors surrounding the southern boundary of the South San Francisco Bay remain preserved for sensitive neo-tropical migrant songbirds like the Pacific-slope flycatcher. I emphasize management of the 
Coyote Creek Field Station to ensure continuous restoration and protection of the site to provide nutritious and quality habitat for migrant species. Future research may seek to fully understand migratory connectivity of Pacific-slope flycatchers, and the location and timing of PSFL populations migrating through the Coyote Creek Field Station will play an important role in better understanding genetic variation, evolution, and environmental adaptability of the species. The role of CCFS as a valuable stopover location for migrating Pacific-slope flycatchers from multiple breeding origins at different times may help wildlife managers track the future spread of disease and parasites, better understand aspects of climate change, and properly track population decline. The methodologies used in this study demonstrate the potential ability for researchers to explore the migratory movements of individuals, or smaller groups of migrants, through temporal data to make inferences about populations. It is my hope that the methodologies used in this study can be improved upon by future researchers and applied in migratory connectivity studies of many other species.

\section{Recommendations for Future Research}

Future research should further refine the geographic origins of migrating Pacificslope flycatchers by expanding the sample size and by sampling flycatchers that pass through other nearby banding stations such as Point Blue Conservation in Point Reyes, CA or local areas where flycatchers have been seen or heard by citizen scientists. This expanded sample would target not only hatching-year Pacific slope flycatchers, but afterhatch year adult Pacific-slope flycatchers as well to make proper inferences of the population as a whole. An interesting phenomenon that has been historically observed at 
the Coyote Creek Field Station is that the proportion of HY to AHY Pacific-slope flycatchers moving through is significantly higher in HY birds (San Francisco Bay Bird Observatory, 2016). Increased incidences of HY birds at stopover sites may be indicative of young birds solely selecting a coastal, or alternative migration route to the routes of adult birds (Ralph, 1981). Additionally, very few AHY birds are observed migrating through CCFS during the spring. A future study that targets HY and AHY birds at periphery locations to CCFS may provide insight on the true migratory movements of the population as a whole, and help quantify any HY mortality events that are likely connected to coastal route selection.

When sampling the Pacific-slope flycatchers, collecting additional morphological data such as presence number of fault bars on flight feathers and tarsus length, keel length and wing span to calculate body size could add valuable data. Expanded analyses could incorporate secondary data sets such as Pacific-slope flycatcher feathers from known breeding origins to better calibrate the deuterium in precipitation maps from (Bowen et al., 2005). These samples would need to be collected through museum specimens or banding stations throughout known breeding sites in western North America. Additional secondary data sets could also include banding and encounter data from the U.S. Geological Survey Bird Banding Laboratory to investigate direction of migratory movements or PSFL Productivity (reproductive index) data from the Institute for Bird Populations Monitoring Avian Productivity and Survivorship program to investigate potential source-sink dynamics. Techniques, such as genetic analyses and or light-level geolocators can also be used to improve estimates of migratory origins. 
Another refinement would be to re-structure the incorporation of $\delta^{13} \mathrm{C}$ and $\delta^{15} \mathrm{~N}$ data into analyses to improve inferences about migratory origin and habitat selection. $\delta^{13} \mathrm{C}$ and $\delta^{15} \mathrm{~N}$ data should only be used if stable isotope data from vegetation and insects across the known Pacific-slope flycatcher breeding range can be collected prior to migration to be used as a basis of comparison. Additionally, the incorporation of compound-specific stable isotope analysis of amino acids, a newer methodology that has shown to improve information about food-web and diet structure in wildlife, could be used.

Finally, a full-circle assesmment of migratory connectivity in Pacific-slope flycatchers should be continued by sampling migratory individuals during the spring to determine geographic origins of their wintering grounds.

Investigations of the probable wintering origins of Pacific-slope flycatchers during spring migration will further quantify the dynamics of the PSFL annual cycle, open more doors for population ecologists to quantify mortality events, and provide concrete spatial and temporal advisement to wildlife managers to prioritize conservation measures in breeding, stopover, or wintering sites. 


\section{References}

Åkesson, S., \& Hedenström, A. (2000). Wind selectivity of migratory flight departures in birds. Behavioral Ecology and Sociobiology, 47, 140-144. http://doi.org/10.1007/s002650050004

American Ornithologists' Union. (1998). Check-list of North American birds. Seventh edition. Washington, D.C.

American Ornithologists' Union and Cooper Ornithological Society. (2016). American Ornithologists Union | American Ornithology. Retrieved September 20, 2016, from http://www.americanornithology.org/content/american-ornithologists-union

Arizaga, J., Alonso, D., \& Hobson, K. A. (2014). Disentangling the origin of crossbills using morphology and isotopic $(\delta 2 \mathrm{H})$ characters. Are southern European crossbills restricted to population-specific key resources? Journal of Ornithology, 155, 10271035. http://doi.org/10.1007/s10336-014-1089-x

Arizaga, J., Van Wilgenburg, S. L., Alonso, D., Cortés, J. A., Leconte, M., Rguibi, H., ... Hobson, K. A. (2016). Breeding origins and pattern of migration of Bluethroats Luscinia svecica wintering from Iberia to Senegal as revealed by stable isotopes. Bird Study, 3657, 1-7. http://doi.org/10.1080/00063657.2016.1182963

Bearhop, S., Furness, R. W., Hilton, G. M., Votier, S. C., \& Waldron, S. (2003). A forensic approach to understanding diet and habitat use from stable isotope analysis of (avian) claw material. Functional Ecology, 17, 270-275. http://doi.org/10.1046/j.1365-2435.2003.00725.x

Becker, R. A., Wilks, A. R., Brownrigg, R., Minka, T. P., \& Deckmyn, A. (2016). Package "maps": Draw Geographical Maps. Retrieved from https://cran.rproject.org/web/packages/maps/maps.pdf

Bell, C. P. (2005). The origin and development of bird migration: comments on Rappole and Jones, and an alternative evolutionary model. Ardea, 93, 115-123.

Bensch, S., Grahn, M., Müller, N., Gay, L., \& Åkesson, S. (2009). Genetic, morphological, and feather isotope variation of migratory willow warblers show gradual divergence in a ring. Molecular Ecology, 18, 3087-3096. http://doi.org/10.1111/j.1365-294X.2009.04210.x

Berthold, P. (2001). Bird migration: a general survey. Oxford University Press on Demand.

BirdLife International. (2008). North American monitoring schemes are revealing 
declines in migratory species. Presented as part of the BirdLife State of the world's birds website. Retrieved January 8, 2016, from

http://www.birdlife.org/datazone/sowb/casestudy/65

BirdLife International. (2012). Empidonax Difficilis. Retrieved August 1, 2016, from http://dx.doi.org/10.2305/IUCN.UK.2012-1.RLTS.T22699871A39098810.en.

BirdLife International and NatureServe. (2015). Bird species distribution maps of the world. Verson 5.0. Dataset, Cambridge, UK and NatureServe, Arlington, USA: BirdLife International.

Bivand, R., Lewin-Koh, N., Pebesma, E., Archer, E., Baddeley, A., Bearman, N., ... Callahan, J. (2016). Package "maptools": Tools for Reading and Handling Spatial Objects. Retrieved from https://cran.rproject.org/web/packages/maptools/maptools.pdf

Both, C., Bouwhuis, S., Lessells, C. M., \& Visser, M. E. (2006). Climate change and population declines in a long-distance migratory bird. Nature, 441, 81-3. http://doi.org/10.1038/nature04539

Both, C., \& Visser, M. E. (2001). Adjustment to climate change is constrained by arrival date in a long-distance migrant bird. Nature, 411, 296-298. http://doi.org/10.1038/35077063

Boulet, M., Gibbs, H. L., \& Hobson, K. A. (2006). Integrated Analysis of Genetic, Stable Isotope, and Banding Data Reveal Migratory Connectivity and Flyways in the Northern Yellow Warbler (Dendroica petechia; Aestiva group). Ornithological Monographs, 61, 29-78.

Bowen, G. J., Liu, Z., Vander Zanden, H. B., Zhao, L., \& Takahashi, G. (2014). Geographic assignment with stable isotopes in IsoMAP. Methods in Ecology and Evolution, 5, 201-206. http://doi.org/10.1111/2041-210X.12147

Bowen, G. J., Wassenaar, L. I., \& Hobson, K. A. (2005). Global application of stable hydrogen and oxygen isotopes to wildlife forensics. Oecologia, 143, 337-348. http://doi.org/10.1007/s00442-004-1813-y

Boyle, W. A., \& Conway, C. J. (2007). Why migrate? A test of the evolutionary precursor hypothesis. The American Naturalist, 169, 344-359. http://doi.org/10.1086/511335

Brennan, L. A., Hernandez, F., \& Williford, D. (1999). Northern Bobwhite (Colinus virginianus). In P. G. Rodewald (Ed.), The Birds of North America Online. Cornell Lab of Ornithology. http://doi.org/10.2173/bna.397 
Buler, J. J., \& Moore, F. R. (2011). Migrant-habitat relationships during stopover along an ecological barrier: Extrinsic constraints and conservation implications. Journal of Ornithology, 152. http://doi.org/10.1007/s10336-010-0640-7

Butcher, G. S., \& Niven, D. K. (2007). Combining Data from the Christmas Bird Count and the Breeding Bird Survey to Determine the Continental Status and Trends of North America Birds. Technical Report.

Carlisle, J. D., Skagen, S. K., Kus, B. E., van Riper, C., Paxton, K. L., \& Kelly, J. F. (2009). Landbird Migration in the American West: Recent Progress and Future Research Directions. The Condor, 111, 211-225. http://doi.org/10.1525/cond.2009.080096

Chamberlain, C. P., Blum, J. D., Holmes, R. T., Xiahong, F., Sherry, T. W., \& Graves, G. R. (1997). The use of isotope tracers for identifying populations of migratory birds. Oecologia, 109, 132-141. Retrieved from file://C:/Users/Dell/Downloads/Chamberlain_1997_Oecol.pdf

Charrad, M., Ghazzali, N., Boiteau, V., \& Niknafs, A. (2015). Package "NbClust": Determining the Best Number of Clusters in a Data Set. Retrieved from https://cran.rproject.org/web/packages/NbClust/NbClust.pdf

Christie, K. S. (2004). Trends in Abundance of Migratory Songbirds at Rocky Point Bird Observatory, Southern Vancouver Island, British Columbia. Technical Report.

Classic Collection of North American Birds. (2016). Extinct Birds of North America. Retrieved January 1, 2016, from http://www.birds-of-north-america.net/extinct-birdsof-north-america.html

Cohen, E. B., Moore, F. R., \& Fischer, R. A. (2014). Fuel stores, time of spring, and movement behavior influence stopover duration of Red-eyed Vireo Vireo olivaceus. Journal of Ornithology, 155, 785-792. http://doi.org/10.1007/s10336-014-1067-3

Cohen, E. B., Németh, Z., Zenzal, T. J., Paxton, K. L., Diehl, R., Paxton, E. H., \& Moore, F. R. (2015). Spring Resource Phenology and Timing of Songbird Migration across the Gulf of Mexico. Studies in Avian Biology, (47), 63-82.

Collar, N. (1992). Threatened Birds of the Americas: The ICBP/IUCN Red Data Book (3rd ed.).

Cox, G. W. (1985). The University of Chicago New World, 126, 451-474.

DeGraaf, R. M., \& Rappole, J. H. (1995). Neotropical migratory birds: natural history, 
distribution, and population change. Cornell University Press.

Delingat, J., Hobson, K. A., Dierschke, V., Schmaljohann, H., \& Bairlein, F. (2011). Morphometrics and stable isotopes differentiate populations of Northern Wheatears (Oenanthe oenanthe). Journal of Ornithology, 152, 383-395. http://doi.org/10.1007/s10336-010-0599-4

Esler, D. (2000). Applying Metapopulation Theory to Conservation of Migratory Birds. Conservation Biology, 14, 366-372. http://doi.org/10.1046/j.1523-1739.2000.98147.x

Evans, K. L., Newton, J., Mallord, J. W., \& Markman, S. (2012). Stable isotope analysis provides new information on winter habitat use of declining avian migrants that is relevant to their conservation. PLOS ONE, 7. http://doi.org/10.1371/journal.pone.0034542

Filzmoser, P., \& Varmuza, K. (2016). Package "chemometrics": Multivariate Statistical Analysis in Chemometrics. Retrieved from https://cran.rproject.org/web/packages/chemometrics/chemometrics.pdf

Fontaine, J. J., Stutzman, R. J., \& Gannes, L. Z. (2015). Leaps, Chains, and Climate Change for Western Migratory Songbirds. Studies in Avian Biology, (47), 3-15.

Fontaine, J. J., \& Van Riper III, C. (2009). A Neotropical Migrant Bird's Dilemma Where to Stop for a Good Meal. Nebraska Cooperative Fish \& Wildlife Research Unit--Staff Publications.

Fraley, C., Raftery, A. E., Scrucca, L., Murphy, T. B., \& Fop, M. (2016). Package "mclust": Gaussian Mixture Modelling for Model-Based Clustering, Classification, and Density Estimation. Retrieved from https://cran.rproject.org/web/packages/mclust/mclust.pdf

Fretwell, S. D. (1972). Populations in a Seasonal Environment.

Fry, B. (2006). Stable Isotope Ecology. Springer New York.

Gagnon, C., \& Hobson, K. A. (2009). Using stable isotopes to track frugivory in migratory passerines. Canadian Journal of Zoology, 87, 981-992. http://doi.org/10.1139/Z09-086

Garcia-Perez, B., \& Hobson, K. A. (2014). A multi-isotope (d2H, d13C, d15N) approach to establishing migratory connectivity of Barn Swallow (Hirundo rustica). Ecosphere, 5, 1-12. http://doi.org/10.3161/000164514X682896

Garcia-Perez, B., Hobson, K. A., Powell, R. L., Still, C. J., \& Huber, G. H. (2013). 
Switching Hemispheres: A New Migration Strategy for the Disjunct Argentinean Breeding Population of Barn Swallow (Hirundo rustica). PLoS ONE, 8. http://doi.org/10.1371/journal.pone.0055654

González-Prieto, A. M., Hobson, K. A., Bayly, N. J., \& Gómez, C. (2011). Geographic Origins and Timing of Fall Migration of the Veery in Northern Colombia. The Condor, 113, 860-868. http://doi.org/10.1525/cond.2011.100245

Goymann, W., Spina, F., Ferri, A., Fusani, L., \& Fusanu, L. (2010). Body fat influences departure from stopover sites in migratory birds: evidence from whole-island telemetry. Biology Letters, 6, 478-481. http://doi.org/10.1098/rsbl.2009.1028

Graham, F. (1990). The Audubon Ark: A History of the National Audubon Society.

Greenway, J. C. (1967). Extinct and Vanishing Birds of the World.

Gunnarsson, G., Latorre-Margalef, N., Hobson, K. A., Van Wilgenburg, S. L., Elmberg, J., Olsen, B., ... Waldenstrom, J. (2012). Disease dynamics and bird migrationlinking mallards Anas platyrhynchos and subtype diversity of the influenza a virus in time and space. PLoS ONE, 7. http://doi.org/10.1371/journal.pone.0035679

Haché, S., Hobson, K. A., Bayne, E. M., Van Wilgenburg, S. L., \& Villard, M. A. (2014). Tracking natal dispersal in a coastal population of a migratory songbird using feather stable isotope $(\delta 2 \mathrm{~h}, \delta 34 \mathrm{~s})$ tracers. PLOS ONE, 9. http://doi.org/10.1371/journal.pone.0094437

Haramis, G. M., Jorde, D. G., Macko, S. A., Walker, J. L., \& Walker, J. L. (2001). Stable-Isotope Analysis of Canvasback Winter Diet in Upper Chesapeake Bay. The Auk, 118, 1008-1017.

Hedenström, A. (2008). Adaptations to migration in birds: behavioural strategies, morphology and scaling effects. Philosophical Transactions of the Royal Society of London. Series B, Biological Sciences, 363, 287-99. http://doi.org/10.1098/rstb.2007.2140

Hervé, M. (2016). Package "RVAideMemoire": Diverse Basic Statistical and Graphical Functions. Retrieved from https://cran.rproject.org/web/packages/RVAideMemoire/RVAideMemoire.pdf

Hijmans, R. J., van Etten, J., Cheng, J., Mattiuzzi, M., Sumner, M., Greenberg, J. A., ... Shortridge, A. (2016). Package "raster": Geographic Data Analysis and Modeling. Retrieved from https://cran.r-project.org/web/packages/raster/raster.pdf

Hobson, K. A. (1999a). Stable-Carbon and Nitrogen Isotope Ratios of Songbird Feathers 
Grown in Two Terrestrial Biomes: Implications for Evaluating Trophic Relationships and Breeding Origins. The Condor, 101, 799-805. http://doi.org/10.2307/1370067

Hobson, K. A. (1999b). Tracing origins and migration of wildlife using stable isotopes: A review. Oecologia, 120, 314-326. http://doi.org/10.1007/s004420050865

Hobson, K. A. (2005). Stable isotopes and the determination of avian migratory connectivity and seasonal interactions. The Auk, 122, 1037-1048.

Hobson, K. A., Mcfarland, K. P., Wassenaar, L. I., Rimmer, C. C., \& Goetz, J. E. (2001). Linking Breeding and Wintering Grounds of Bicknell's Thrushes Using Stable Isotope Analyses of Feathers. The Auk, 118, 16-23.

Hobson, K. A., \& Norris, R. D. (2008). Animal Migration: A Context for Using New Techniques and Approaches. Terrestrial Ecology, 2(2008), 1-19. http://doi.org/10.1016/S1936-7961(07)00001-2

Hobson, K. A., Van Wilgenburg, S. L., Dunn, E. H., Hussell, D. J. T., Taylor, P. D., \& Collister, D. M. (2015). Predicting origins of passerines migrating through Canadian migration monitoring stations using stable-hydrogen isotope analyses of feathers: a new tool for bird conservation. Avian Conservation and Ecology, 10, 3. http://doi.org/10.5751/ACE-00719-100103

Hobson, K. A., Van Wilgenburg, S. L., Faaborg, J., Toms, J. D., Rengifo, C., Sosa, A. L., ... Brito Aguilar, R. (2014). Connecting breeding and wintering grounds of Neotropical migrant songbirds using stable hydrogen isotopes: A call for an isotopic atlas of migratory connectivity. Journal of Field Ornithology, 85, 237-257. http://doi.org/10.1111/jofo.12065

Hobson, K. A., Van Wilgenburg, S. L., Ferrand, Y., Gossman, F., \& Bastat, C. (2013). A stable isotope $(\mathrm{d} 2 \mathrm{H})$ approach to deriving origins of harvested woodcock (Scolopax rusticola) taken in France. European Journal of Wildlife Research, 59, 881-892. http://doi.org/10.1007/s10344-013-0742-7

Hobson, K. A., Van Wilgenburg, S. L., Wassenaar, L. I., \& Larson, K. (2012). Linking hydrogen $(\mathrm{d} 2 \mathrm{H})$ isotopes in feathers and precipitation: Sources of variance and consequences for assignment to isoscapes. PLOS ONE, 7. http://doi.org/10.1371/journal.pone.0035137

Hobson, K. A., van Wilgenburg, S. L., Wassenaar, L. I., Powell, R. L., Still, C. J., \& Crane, J. M. (2012). A multi-isotope $(\delta 13 \mathrm{C}, \delta 15 \mathrm{~N}, \delta 2 \mathrm{H})$ feather isoscape to assign Afrotropical migrant birds to origins. Ecosphere, 3, 44. http://doi.org/10.3161/000164514X682896 
Hobson, K. A., Van Wilgenburg, S. L, Wassenaar, L. I., Hands, H., Johnson, W. P., O’Meilia, M., \& Taylor, P. (2006). Using Stable Hydrogen Isotope Analysis of Feathers to Delineate Origins of Harvested Sandhill Cranes in the Central Flyway of North America. Waterbirds, 29, 137-147. http://doi.org/10.1675/15244695(2006)29[137:USHIAO]2.0.CO;2

Hobson, K. A., \& Wassenaar, L. I. (1997). Linking breeding and wintering grounds of neotropical migrant songbirds using stable hydrogen isotopic analysis of feathers. Oecologia, 109, 142-148. http://doi.org/10.1007/s004420050068

Hobson, K. A., Wassenaar, L. I., \& Taylor, O. R. (1999). Stable isotopes (dD and d13C) are geographic indicators of natal origins of monarch butterflies in eastern North America. Oecologia, 120, 397-404. http://doi.org/10.1007/s004420050872

Hobson, K. A., Van Wilgenburg, S. L., Wassenaar, L. I., Moore, F., \& Farrington, J. (2007). Estimating Origins of Three Species of Neotropical Migrant Songbirds at a Gulf Coast Stopover Site: Combining Stable Isotope and GIS Tools. The Condor, 109, 256-267. http://doi.org/10.2307/4500958

Hobson, K. A., Wunder, M. B., Van Wilgenburg, S. L., Clark, R. G., \& Wassenaar, L. I. (2009). A method for investigating population declines of migratory birds using stable isotopes: Origins of harvested lesser scaup in North America. PLoS ONE, 4. http://doi.org/10.1371/journal.pone.0007915

Holberton, R. L., Van Wilgenburg, S. L., Leppold, A. J., \& Hobson, K. A. (2015). Isotopic (d2Hf) evidence of "loop migration" and use of the Gulf of Maine Flyway by both western and eastern breeding populations of Blackpoll Warblers. Journal of Field Ornithology, 86, 213-228. http://doi.org/10.1111/jofo.12112

Holmes, R. T. (2007). Understanding population change in migratory songbirds: Longterm and experimental studies of Neotropical migrants in breeding and wintering areas. Ibis, 149, 2-13. http://doi.org/10.1111/j.1474-919X.2007.00685.x

Hopkins, J. B., \& Ferguson, J. M. (2012). Estimating the diets of animals using stable isotopes and a comprehensive Bayesian mixing model. PLOS ONE, 7. http://doi.org/10.1371/journal.pone.0028478

Hume, J. P., \& Walters, M. (2013). Extinct Birds (Poyser Monographs).

Inger, R., \& Bearhop, S. (2008). Applications of stable isotope analyses to avian ecology. Ibis, 150, 447-461. Retrieved from http://doi.wiley.com/10.1111/j.1474919X.2008.00839.x

International Atomic Energy Agency. (2014). Water Resources Programme - Global 
Network of Isotopes in Precipitation. Retrieved September 26, 2016, from http://www-naweb.iaea.org/napc/ih/IHS_resources_gnip.html

IUCN. (2016a). IUCN Red List version 2016-1: Table 3a. Retrieved July 11, 2016, from http://www.iucnredlist.org/about/summary-statistics\#Tables_3_4

IUCN. (2016b). IUCN Red List Version 2016-1: Table 5. Retrieved July 11, 2016, from http://www.iucnredlist.org/about/summary-statistics\#Tables_5_6

Jaramillo, A., Hudson, S. E., \& Strong, C. M. (1996). Coyote Creek Field Station TenYear Report, 1987-1996. San Francisco Bay Bird Observatory.

Johnson, N. K., \& Marten, J. A. (1988). Evolutionary Genetics of Flycatchers. II. Differentiation in the Empidonax Difficilis Complex. The Auk, 105, 177-191.

Jones, M. R., \& Witt, C. C. (2014). Migrate small, sound big: Functional constraints on body size promote tracheal elongation in cranes. Journal of Evolutionary Biology, 27, 1256-1264. http://doi.org/10.1111/jeb.12397

Kaboli, M., Aliabadian, M., Guillaumet, A., Roselaar, C. S., \& Prodon, R. (2007). Ecomorphology of the wheatears (genus Oenanthe). Ibis, 149, 792-805. http://doi.org/10.1111/j.1474-919X.2007.00714.X

Kelly, J. F. (2000). Stable isotopes of carbon and nitrogen in the study of avian and mammalian trophic ecology. Canadian Journal of Zoology, 78, 1-27. http://doi.org/10.1139/z99-165

Kelly, J. F. (2006). Stable isotope evidence links breeding geography and migration timing in wood warblers (Parulidae). The Auk, 123, 431-437. http://doi.org/10.1642/0004-8038(2006)123[431:sielbg]2.0.co;2

Kelly, J. F., Atudorei, V., Sharp, Z. D., \& Finch, D. M. (2002). Insights into Wilson's Warbler migration from analyses of hydrogen stable-isotope ratios. Oecologia, 130, 216-221. http://doi.org/10.1007/s004420100789

Kelly, J. F., Finch, D. M., \& Yong, W. (2000). Southwestern Association of Naturalists Vegetative Associations of Wood Warblers Migrating along the Middle Rio Grande Valley, New Mexico. Southwestern Association of Naturalists, 45, 159-168.

Kempster, B., Zanette, L., Longstaffe, F. J., MacDougall-Shackleton, S. A., Wingfield, J. C., \& Clinchy, M. (2007). Do stable isotopes reflect nutritional stress? Results from a laboratory experiment on song sparrows. Oecologia, 151, 365-371. http://doi.org/10.1007/s00442-006-0597-7 
Kendall, C., Sklash, M. G., \& Bullen, T. D. (1995). Isotope Tracers of Water and Solute Sources in Catchments. In Solute Modelling in Catchment Systems (pp. 261-303). New York: J. Wiley \& Sons.

Klaassen, M. (1996). Metabolic constraints on long-distance migration in birds. The Journal of Experimental Biology, 199, 57-64. Retrieved from http://www.ncbi.nlm.nih.gov/pubmed/9317335

Kuvlesky, W. P., Brennan, L. A., Morrison, M. L., Boydston, K. K., Ballard, B. M., \& Bryant, F. C. (2007). Wind Energy Development and Wildlife Conservation: Challenges and Opportunities. The Journal of Wildlife Management, 71, 2487-2498. http://doi.org/10.2193/2007-248

Lajtha, K., \& Marshall, J. D. (1994). Sources of variation in the stable isotopic composition of plants. In K. Lajtha \& R. H. Michener (Eds.), Stable isotopes in ecology and environmental science (pp. 1-21). Blackwell.

Ligges, U., Maechler, M., \& Schnackenberg, S. (2016). Package "scatterplot3d": 3D Scatter Plot. Retrieved from https://cran.rproject.org/web/packages/scatterplot3d/scatterplot3d.pdf

Lindström, Å., Klaassen, M., Piersma, T., Holmgren, N., \& Wennerberg, L. (2002). Fuel Stores of Juvenile Waders on Autumn Migration in High Arctic Canada. Ardea, 90, 93-102.

Lowther, P. E. (2000). Pacific-slope Flycatcher (Empidonax difficilis). In The Birds of North America Online (A.Poole, Ed.). Cornell Lab or Ornithology. Retrieved from http://bna.birds.cornell.edu/bna/species/556a

Maggini, I., Spina, F., Voigt, C. C., Ferri, A., \& Bairlein, F. (2013). Differential migration and body condition in Northern Wheatears (Oenanthe oenanthe) at a Mediterranean spring stopover site. Journal of Ornithology, 154, 321-328. http://doi.org/10.1007/s10336-012-0896-1

Magoc, C. J. (2006). Environmental Issues in American History: A Reference Guide with Primary Documents (Major Issues in American History).

Marra, P., Hobson, K. A., \& Holmes, R. T. (1998). Linking Winter and Summer Events in a Migratory Bird by Using Stable-Carbon Isotopes. Science, 282, 1884-1886. http://doi.org/10.1126/science.282.5395.1884

Marra, P. P., Norris, R. D., Haig, S. M., Webster, M. S., \& Royle, A. J. (2006). Migratory Connectivity. In K. Crooks \& M. Sanjayan (Eds.), Connectivity Conservation (pp. 157-183). New York: Cambridge University Press. 
Marshall, J. D., Brooks, J. R., \& Lajtha, K. (2007). Sources of variation in the stable isotopic composition of plants. Stable Isotopes in Ecology and Environmental Science, 22-59. http://doi.org/10.1002/9780470691854.ch2

Martin, P. S., \& Wright, H. E. (1967). Pleistocene Extinctions: The Search for a Cause.

Matthews, J. (2016). Personal Communication.

Mazerolle, D. F., Hobson, K. A., \& Wassenaar, L. I. (2005). Stable isotope and bandencounter analyses delineate migratory patterns and catchment areas of whitethroated sparrows at a migration monitoring station. Oecologia, 144, 541-549. http://doi.org/10.1007/s00442-005-0031-6

Meehan, T. D., Giermakowski, J. T., \& Cryan, P. M. (2004). GIS-based model of stable hydrogen isotope ratios in North American growing-season precipitation for use in animal movement studies. Isotopes in Environmental and Health Studies, 40, 291300. http://doi.org/10.1080/10256010410001731404

Mehlman, D. W., Mabey, S. E., Ewert, D. N., Duncan, C., Abel, B., Cimprich, D., ... Woodrey, M. (2005). Conserving Stopover Sites for Forest-Dwelling Migratory Landbirds. The Auk, 122, 1281-1290.

Meissner, W. (1996). Timing and phenology of autumn migration of common sandpiper (Actitis hypoleucos) at the Gulf of Gdańsk. The Ring, 18, 59-72.

Meissner, W. (2009). A classification scheme for scoring subcutaneous fat depots of shorebirds. Journal of Field Ornithology, 80, 289-296. http://doi.org/10.1111/j.15579263.2009.00232.x

Milá, B., Wayne, R. K., \& Smith, T. B. (2008). Ecomorphology Of Migratory And Sedentary Populations Of The Yellow-Rumped Warbler (Dendroica coronata). The Condor, 110, 335-344. http://doi.org/10.1525/cond.2008.8396

Milligan, G. W., \& Cooper, M. C. (1985). An examination of procedures for determining the number of clusters in a data set. Psychometrika, 50, 159-179.

Milligan, G. W., \& Cooper, M. C. (1988). A study of standardization of variables in cluster analysis. Journal of Classification, 5, 181-204. http://doi.org/10.1007/BF01897163

Møller, A. P., \& Hobson, K. A. (2004). Heterogeneity in stable isotope profiles predicts coexistence of populations of barn swallows Hirundo rustica differing in morphology and reproductive performance. Proceedings of the Royal Society of London. Series B: 
Biological Sciences, 271, 1355-1362. http://doi.org/10.1098/rspb.2003.2565

Møller, A. P., Rubolini, D., \& Lehikoinen, E. (2008). Populations of migratory bird species that did not show a phenological response to climate change are declining. Proceedings of the National Academy of Sciences of the United States of America, 105, 16195-16200. http://doi.org/10.1073/pnas.0803825105

Monroe, B. L., Banks, R. C., Fitzpatrick, J. W., Howell, T. R., Johnson, N. K., Ouellet, H., ... Storer, R. W. (1989). Thirty-Seventh Supplement to the American Ornithologists' Union Check-List of North American Birds. The Auk, 106, 532-538.

Moore, F. R., \& Aborn, D. A. (2000). Mechanisms of en route habitat selection: how do migrants make habitat decisions during stopover? Studies in Avian Biology, 20, 3442.

Moore, F. R., Kerlinger, P., \& Simons, T. R. (1990). Stopover on a Gulf coast barrier island by spring trans-Gulf migrants. The Wilson Bulletin, 102, 487-500. Retrieved from http://www.jstor.org/stable/4162904

Moore, F. R., Smith, R. J., \& Sandberg, R. (2005). Stopover ecology of intercontinental migrants : solutions to problems and consequences for reproductive performance. In R. Greenberg \& P. P. Marra (Eds.), Birds of Two Worlds: The Ecology and Evolution of Migration (pp. 251-261). Smithsonian Institution.

Morris, S. R., Holmes, D. W., \& Richmond, M. E. (1996). A ten-year study of the stopover patterns of migratory passerines during fall migration on Appledore Island, Maine. The Condor, 98, 395-409. http://doi.org/10.2307/1369157

National Oceanic and Atmospheric Administration. (2016). Global Historical Climatology Network (GHCN). Retrieved January 1, 2016, from https://www.ncdc.noaa.gov/data-access/land-based-station-data/land-baseddatasets/global-historical-climatology-network-ghen

Newton, I. (2004). Population limitation in migrants. Ibis, 146, 197-226. http://doi.org/10.1111/j.1474-919X.2004.00293.x

Nocedal, J. (1994). Local migrations of insectivorous birds in western Mexico: implications for the protection and conservation of their habitats. Bird Conservation International, 4, 129-142.

Norris, D. R., Marra, P. P., Kyser, T. K., Sherry, T. W., \& Ratcliffe, L. M. (2004). Tropical winter habitat limits reproductive success on the temperate breeding grounds in a migratory bird. Proceedings. Biological Sciences / The Royal Society, 271, 5964. http://doi.org/10.1098/rspb.2003.2569 
North American Bird Conservation Initiative. (2016). The State of North America's Birds 2016. Ottawa, Ontario. Retrieved from www.stateofthebirds.org

Nowakowski, J. K., Szulc, J., \& Remisiewicz, M. (2014). The further the flight, the longer the wing: Relationship between wing length and migratory distance in Old World reed and bush Warblers (Acrocephalidae and Locustellidae). Ornis Fennica, 91, 178-186.

Orben, R. (2014). Feather Cleaning Recommendations for Stable Isotope Analysis. Personal Communication.

Paritte, J. M., \& Kelly, J. F. (2009). Effect of cleaning regime on stable-isotope ratios of feathers in Japanese Quail (Coturnix japonica). The Auk, 126, 165-174. http://doi.org/10.1525/auk.2009.07187

Paxton, E. H. (2008). Geographic variation and migratory connectivity of willow flycatcher subspecies. Dissertation.

Paxton, K. L., \& Moore, F. R. (2015). Carry-over effects of winter habitat quality on en route timing and condition of a migratory passerine during spring migration. Journal of Avian Biology, 46, 495-506. http://doi.org/10.1111/jav.00614

Paxton, K. L., Van Riper III, C., Theimer, T. C., \& Paxton, E. H. (2007). Spatial and Temporal Migration Patterns of Wilson's Warbler (Wilsonia Pusilla) in the Southwest As Revealed By Stable Isotopes. The Auk, 124, 162-175. http://doi.org/10.1642/0004-8038(2007)124

Paxton, K. L., Yau, M., Moore, F. R., \& Irwin, D. E. (2013). Differential migratory timing of western populations of Wilson's Warbler (Cardellina pusilla) revealed by mitochondrial DNA and stable isotopes. The Auk, 130, 689-698. http://doi.org/10.1525/auk.2013.13107

Pearson, S. F., Levey, D. J., Greenberg, C. H., \& Martínez Del Rio, C. (2003). Effects of elemental composition on the incorporation of dietary nitrogen and carbon isotopic signatures in an omnivorous songbird. Oecologia, 135, 516-23. http://doi.org/10.1007/s00442-003-1221-8

Pérez, G. E., \& Hobson, K. A. (2007). Feather deuterium measurements reveal origins of migratory western loggerhead shrikes (Lanius ludovicianus excubitorides) wintering in Mexico: Biodiversity research. Diversity and Distributions, 13, 166-171. http://doi.org/10.1111/j.1472-4642.2006.00306.x

Pérez-Tris, J., \& Tellería, J. (2003). Age-related variation in wing shape of migratory and 
sedentary Blackcaps Sylvia atricapilla. Journal of Avian Biology, 32, 207-213. http://doi.org/10.1111/j.0908-8857.2001.320301.x

Peterson, B. J., \& Fry, B. (1987). Stable Isotopes in Ecosystem Studies. Annual Review of Ecology and Systematics, 18, 293-320.

Pillar, A. G., Marra, P., Flood, N. J., \& Reudink, M. W. (2016). Moult Migration in Bullock's orioles (Icterus bullockii) confirmed by geolocators and stable isotope analysis. Journal of Ornithology, 157, 265-275.

Plummer, L. N., Michel, R. L., Thurman, E. M., \& Glynn, P. D. (1993). Environmental tracers for age dating young ground water. In W. M. Alley (Ed.), Regional GroundWater Quarterly (pp. 255-294). New York: Reinhold, V. N.

Post, D. M. (2002). Using stable isotopes to estimate trophic position: model, methods, and assumptions. Ecology, 83, 703-718. http://doi.org/10.1890/00129658(2002)083[0703:USITET]2.0.CO;2

Pyle, P., Institute for Bird Populations, \& Point Reyes Bird Observatory. (1997). Identification Guide to North American Birds, Part I: Columbidae to Ploceidae. Slate Creek Press.

Quinn, G. P., \& Keough, M. J. (2002). Experimental Design and Data Analysis for Biologists. New York: Cambridge University Press.

R Core Team. (2015). R: A Language and Environment for Statistical Computing. Vienna, Austria: The R Foundation for Statistical Computing. Retrieved from https://www.r-project.org

Ralph, C. J. (1981). Age ratios and their possible use in determining autumn routes of passerine migrants. The Wilson Bulletin, 93, 164-188. Retrieved from http://www.jstor.org/stable/10.2307/4161458 Inpapers2://publication/uuid/FA12B7225759-403E-BA75-595AAC58A088

Raphael, M. G., Rosenberg, K. V., \& Marcot, B. G. (1988). Large-scale changes in bird populations of Douglas-fir forests, northwestern California. In Bird Conservation 3 (pp. 63-83). Madison, Wisconsin: The Board of Regents of the University of Wisconsin System.

Reudink, M. W., Van Wilgenburg, S. L., Steele, L. S., Pillar, A. G., Marra, P. P., \& McKellar, A. E. (2015). Patterns of migratory connectivity in Vaux's Swifts at a northern migratory roost: A multi-isotope approach. The Condor, 117, 670-682. http://doi.org/10.1650/CONDOR-15-82.1 
Rigney, M., Katano, B., \& Otahal, C. (1993). Coyote Creek Flood Control Project, pilot revegetation site, wildlife program, five-year summary report 1988-1992. San Jose.

Rigney, M., Katano, B., \& Otahal, C. (1994). Coyote Creek Flood Control Project, pilot revegetation site, wildlife program, 1993-1994 annual report. San Jose, California.

Rigney, M., Mewaldt, L. R., Wolf, B. O., \& Duke, R. R. (1989). Wildlife monitoring of a riparian mitigation site. Proceedings of the California Riparian Systems Conference: Protection, Management, and Restoration for the 1990s. General Technical Report PSW-110, 319-324.

Rosenberg, K. V., Ohmart, R. D., Hunter, W. C., \& Anderson, B. W. (1991). Birds of the Lower Colorado River Valley. Tucson: University of Arizona Press.

Royle, A. J., \& Rubenstein, D. R. (2004). The Role of Species Abundance in Determining Breeding Origins of Migratory Birds with Stable Isotopes. Ecolological Applications, 14, 1780-1788.

Rubenstein, D. R., Chamberlain, C. P., Holmes, R. T., Ayres, M. P., Waldbauer, J. R., Graves, G. R., \& Tuross, N. C. (2002). Linking Breeding and Wintering Ranges of a Migratory Songbird Using Stable Isotopes. Science, 295, 1062-1065.

Ruegg, K. C., Anderson, E. C., Paxton, K. L., Apkenas, V., Lao, S., Siegel, R. B., ... Smith, T. B. (2014). Mapping migration in a songbird using high-resolution genetic markers. Molecular Ecology, 23, 5726-5739. http://doi.org/10.1111/mec.12977

Rundel, C. W., Wunder, M. B., Alvarado, A. H., Ruegg, K. C., Harrigan, R., Schuh, A., ... Novembre, J. (2013). Novel statistical methods for integrating genetic and stable isotope data to infer individual-level migratory connectivity. Molecular Ecology, 22, 4163-4176. http://doi.org/10.1111/mec.12393

Rush, A. C., Cannings, R. J., \& Irwin, D. E. (2009). Analysis of multilocus DNA reveals hybridization in a contact zone between Empidonax flycatchers. Journal of Avian Biology, 40, 614-624. http://doi.org/10.1111/j.1600-048X.2009.04681.x

Rushing, C. S., Ryder, T. B., Marra, P. P., \& Rushing, C. S. (2016). Quantifying drivers of population dynamics for a migratory bird throughout the annual cycle. Proceedings of the Royal Society B: Biological Sciences, 283, 20152846. http://doi.org/10.1098/rspb.2015.2846

San Francisco Bay Bird Observatory. (2016). Western Flycatcher Data from the Coyote Creek Field Station 1983-2015. Unpublished raw data.

Sauer, J. R., Hines, J. E., \& Fallon, J. (2007). The North American Breeding Bird Survey, 
results and analysis 1966-2007. Version 10.13.2007. Laurel, MD.

Sauer, J. R., Hines, J. E., Fallon, J. E., Pardieck, D. J., Ziolkowski Jr., D. J., \& Link, W. A. (2014). The North American Breeding Bird Survey, Results and Analysis 1966 2012. Version 02.19.2014. Dataset, Laurel, MD: USGS Patuxent Wildlife Research Center.

Sauer, J. R., Hines, J. E., Gough, G., Thomas, I., \& Peterjohn, B. G. (1997). The North American Breeding Bird Survey Results and Analysis. Version 96.4. Dataset, Laurel, MD: Patuxent Wildlife Research Center.

Schaub, M., Jenni, L., \& Bairlein, F. (2008). Fuel stores, fuel accumulation, and the decision to depart from a migration stopover site. Behavioral Ecology, 19, 657-666. http://doi.org/10.1093/beheco/arn023

Shaffer, S. A., Tremblay, Y., Weimerskirch, H., Scott, D., Thompson, D. R., Sagar, P. M., ... Costa, D. P. (2006). Migratory shearwaters integrate oceanic resources across the Pacific Ocean in an endless summer. Proceedings of the National Academy of Sciences of the United States of America, 103, 12799-802. http://doi.org/10.1073/pnas.0603715103

Shaffer, S. A., Weimerskirch, H., \& Costa, D. P. (2001). Functional significance of sexual dimorphism in Wandering Albatrosses,Diomedea exulans. Functional Ecology, 15, 203-210. http://doi.org/10.1046/j.1365-2435.2001.00514.x

Sillett, T. S., \& Holmes, R. T. (2002). Variation in survivorship of a migratory songbird throughout its annual cycle. Journal of Animal Ecology, 71, 296-308. Retrieved from http://doi.wiley.com/10.1046/j.1365-2656.2002.00599.x InISI:000174986700013

Skagen, S. K., Kelly, J. F., Van Riper III, C., Hutto, R. L., Finch, D. M., Krueper, D. J., \& Melcher, C. P. (2005). Geography of Spring Landbird Migration through Riparian Habitats in Southwestern North America. The Condor, 107, 212-227.

Sol, D., Lefebvre, L., \& Rodríguez-Teijeiro, J. D. (2005). Brain size, innovative propensity and migratory behaviour in temperate Palaearctic birds. Proceedings. Biological Sciences / The Royal Society, 272, 1433-41. http://doi.org/10.1098/rspb.2005.3099

Solovyeva, D., Hobson, K. A., Kharitonova, N., Newton, J., Fox, J. W., Afansyev, V., \& Fox, A. D. (2015). Combining stable hydrogen $(\delta 2 \mathrm{H})$ isotopes and geolocation to assign Scaly-sided Mergansers to moult river catchments. Journal of Ornithology, 157, 663-669. http://doi.org/10.1007/s10336-015-1319-x

Still, C. J., Berry, J. A., Collatz, G. J., \& DeFries, R. S. (2003). Global distribution of C3 
and C4 vegetation: carbon cycle implications. Global Biogeochemical Cycles, 17.

Still, C. J., \& Powell, R. L. (2010). Continental-scale distributions of vegetation stable carbon isotope ratios. In J. B. West, G. J. Bowen, T. E. Dawson, \& K. P. Tu (Eds.), Isoscapes: understanding movements, pattern and process on Earth through isotope mapping (pp. 179-194). New York: Springer New York.

Sullins, D. S., Conway, W. C., Haukos, D. A., Hobson, K. A., Wassenaar, L. I., Comer, C. E., \& Hung, I. K. (2016). American woodcock migratory connectivity as indicated by hydrogen isotopes. Journal of Wildlife Management, 80, 510-526. http://doi.org/10.1002/jwmg.1035

Taketa, E. (2013). 2013 CCFS Vegetation Data. Unpublished raw data.

The Editors of Encyclopædia Britannica. (2006). Coast Ranges Mountains, North America. In Encyclopadia Britannica.

Thomas, C. D., Cameron, A., Green, R. E., Bakkenes, M., Beaumont, L. J., Collingham, Y. C., ... Williams, S. E. (2004). Extinction risk from climate change. Nature, 427(February), 145-148. http://doi.org/10.1038/nature02121

Turner, M., \& Kuhlmann, E. (2014). Trees and Shrubs of the Pacific Northwest. Timber Press, Inc.

U.C. Davis Stable Isotope Facility. (2014a). Carbon (13C) and Nitrogen (15N) Analysis of Solids by EA-IRMS. Retrieved September 26, 2016, from http://stableisotopefacility.ucdavis.edu/13cand15n.html

U.C. Davis Stable Isotope Facility. (2014b). Oxygen (18O) and Hydrogen (D/H) Analysis of Solids by TC/EA-IRMS. Retrieved September 21, 2016, from http://stableisotopefacility.ucdavis.edu/18osolids.html

U.S. Department of the Interior, \& U.S. Geological Survey. (2016). Why Band Birds? Retrieved April 4, 2016, from https://www.pwrc.usgs.gov/BBL/homepage/whyband.cfm

U.S. Fish \& Wildlife Service. (2016a). Neotropical Migratory Bird Conservation Act Bird List. Retrieved September 20, 2016, from https://www.fws.gov/birdhabitat/grants/nmbca/birdlist.shtm

U.S. Fish \& Wildlife Service. (2016b). U.S. Fish \& Wildlife Service - Migratory Bird Program | Conserving America's Birds. Retrieved September 20, 2016, from https://www.fws.gov/birds/policies-and-regulations/laws-legislations/migratory-birdtreaty-act.php 
Urban, M. C. (2015). Accelerating extinction risk from climate change. Science, 348.

Vágási, C. I., Pap, P. L., Vincze, O., Osváth, G., Erritzøe, J., \& Møller, A. P. (2016). Morphological Adaptations to Migration in Birds. Evolutionary Biology, 43, 48-59. http://doi.org/10.1007/s11692-015-9349-0

Van Wilgenburg, S. L. (2016). Personal Communication.

Van Wilgenburg, S. L., \& Hobson, K. A. (2011). Combining stable-isotope (dD) and band recovery data to improve probabilistic assignment of migratory birds to origin. Ecological Applications, 21, 1340-1351. http://doi.org/10.1890/09-2047.1

Waller, S. S., \& Lewis, J. K. (1979). Occurrence of C3 and C4 Photosynthetic pathways in North American grasses. Journal Of Range Management, 32(1), 12-28. http://doi.org/10.2307/3897378

Wassenaar, L. I. (2008). An Introduction to Light Stable Isotopes for Use in Terrestrial Animal Migration Studies. In Tracking Animal Migration with Stable Isotopes: Terrestrial Ecology Volume 2 (pp. 21-44).

Wassenaar, L. I., \& Hobson, K. A. (2000a). Improved method for determining the stablehydrogen isotopic composition (dD) of complex organic materials of environmental interest. Environmental Science and Technology, 34, 2354-2360. http://doi.org/10.1021/es990804i

Wassenaar, L. I., \& Hobson, K. A. (2000b). Stable-Carbon and Hydrogen Isotope Ratios Reveal Breeding Origins of Red-Winged Blackbirds. Ecological Applications, 10, 911-916.

Wassenaar, L. I., \& Hobson, K. A. (2003). Comparative equilibration and online technique for determination of non-exchangeable hydrogen of keratins for use in animal migration studies. Isotopes in Environmental and Health Studies, 39, 211 217. http://doi.org/10.1080/1025601031000096781

Webster, M. S., \& Marra, P. P. (2005). The Importance of understanding migratory connectivity and seasonal interactions. Birds of Two Worlds: The Ecology and Evolution of Migration, 199-209.

Webster, M. S., Marra, P. P., Haig, S. M., Bensch, S., \& Holmes, R. T. (2002). Links between worlds: Unraveling migratory connectivity. Trends in Ecology and Evolution, 17, 76-83.

Wichmann, G., Barker, J., Zuna-Kratky, T., Donnerbaum, K., \& Rössler, M. (2004). 
Age-related stopover strategies in the Wood Sandpiper Tringa glareola. Ornis Fennica, 81, 169-179.

Wolf, B. O., Mewaldt, L. R., Rigney, M., Duke, R. R., \& Hopkins, R. (1989). Coyote Creek Wildlife Monitoring Annual Report, July 1988-June 1989. San Jose, California.

Woodworth, B. K., Newman, A. E. M., Turbek, S. P., Dossman, B. C., Hobson, K. A., Wassenaar, L. I., ... Norris, D. R. (2016). Differential migration and the link between winter latitude, timing of migration, and breeding in a songbird. Oecologia, (February), 1-10. http://doi.org/10.1007/s00442-015-3527-8

Wunder, M. B. (2010). Using Isoscapes to Model Probability Surfaces for Determining Geographic Origins. In J. B. West (Ed.), Isoscapes: Understanding Movement, Pattern, and Process on Earth Through Isotope Mapping (pp. 251-279). Springer Science + Business Media.

Wunder, M. B. (2012). Determining geographic patterns of migration and dispersal using stable isotopes in keratins. Journal of Mammalogy, 93, 360-367. http://doi.org/10.1644/11-MAMM-S-182.1

Wunder, M. B. (2007). Geographic structure and dynamics in Mountain Plover. Dissertation.

Wunder, M. B., \& Norris, D. R. (2008). Improved estimates of certainty in stableisotope-based methods for tracking migratory animals. Ecological Applications, 18, 549-559. http://doi.org/10.1890/07-0058.1

Yong, W., \& Moore, F. R. (1997). Spring Stopover of Intercontinental Migratory Thrushes along the Northern Coast of the Gulf of Mexico. The Auk, 114, 263-278.

Zink, R. M. (2011). The evolution of avian migration. Biological Journal of the Linnean Society, 104, 237-250. 
APPENDIX A: Example of a field data sheet
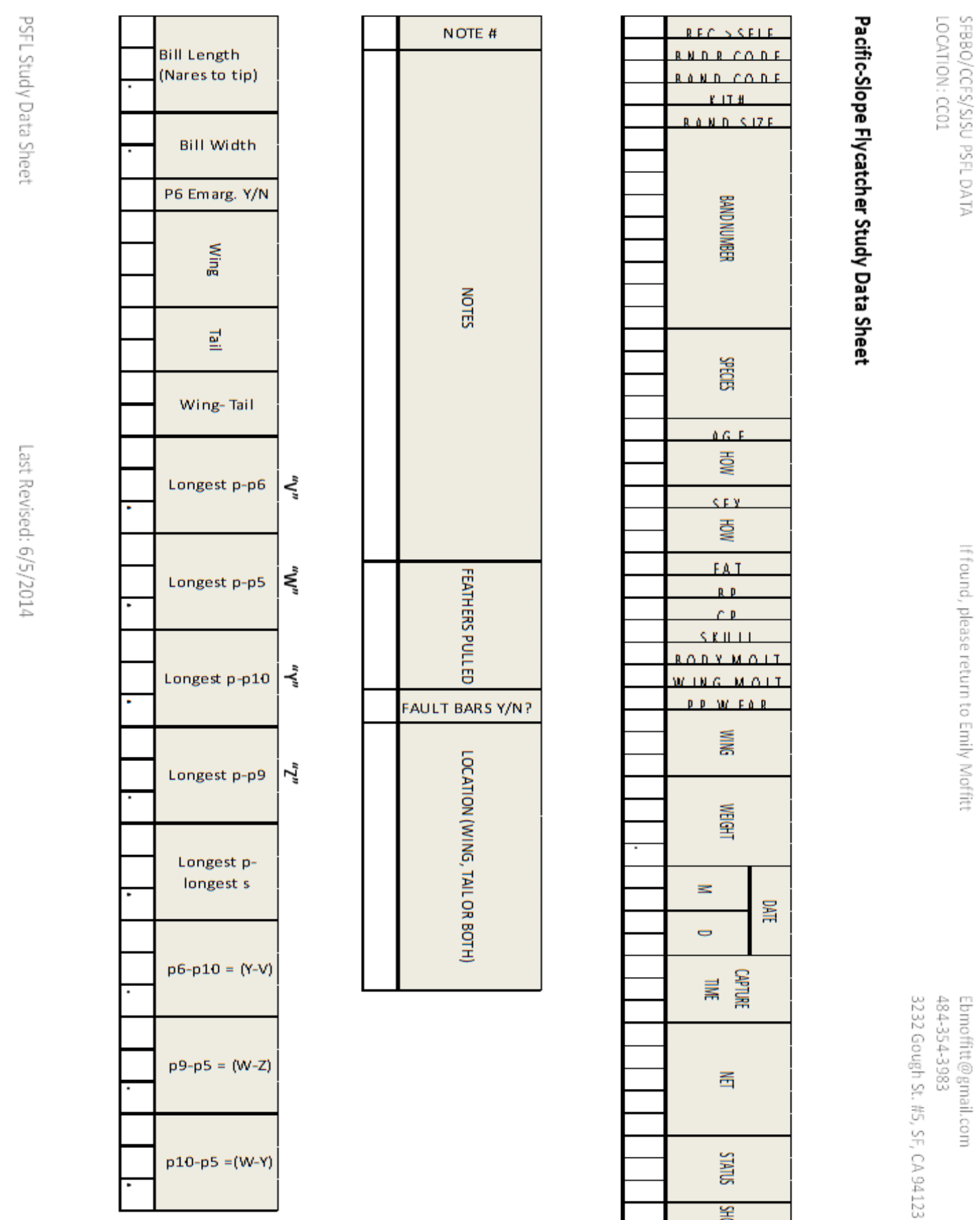

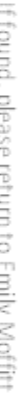




\section{APPENDIX B: Weekly Assignment Models}

(A)

\section{Week 1}

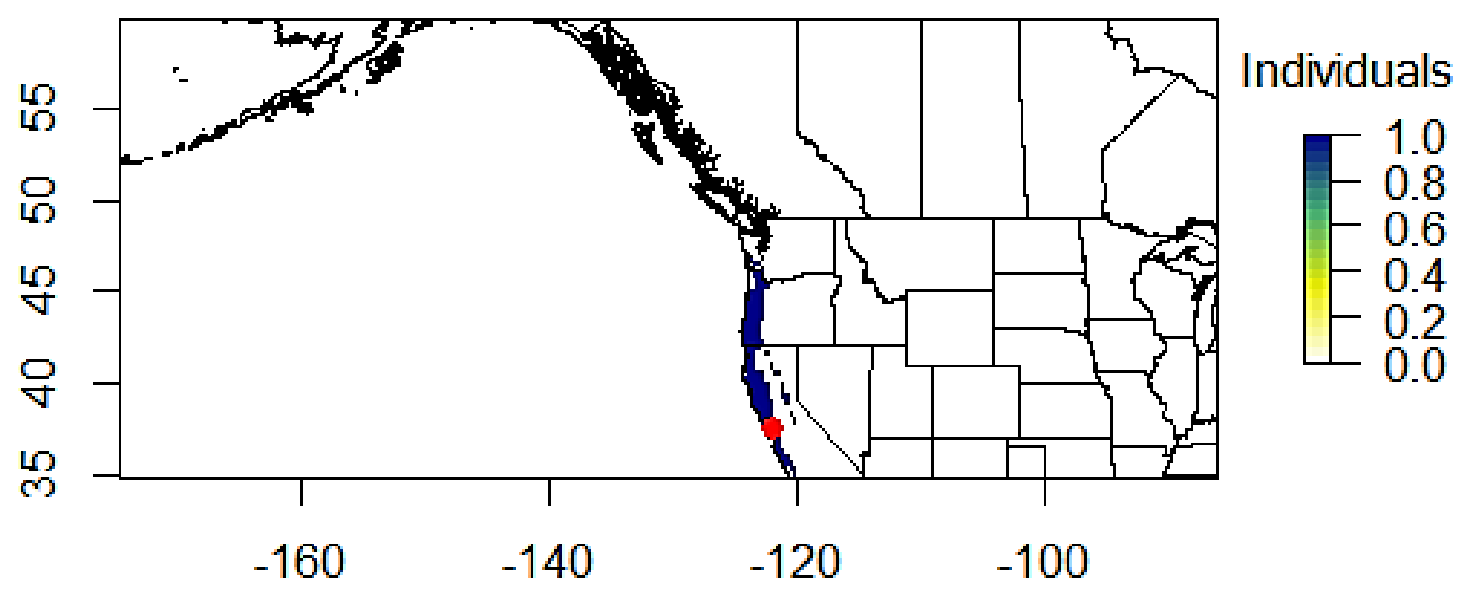

(B)

Week 2

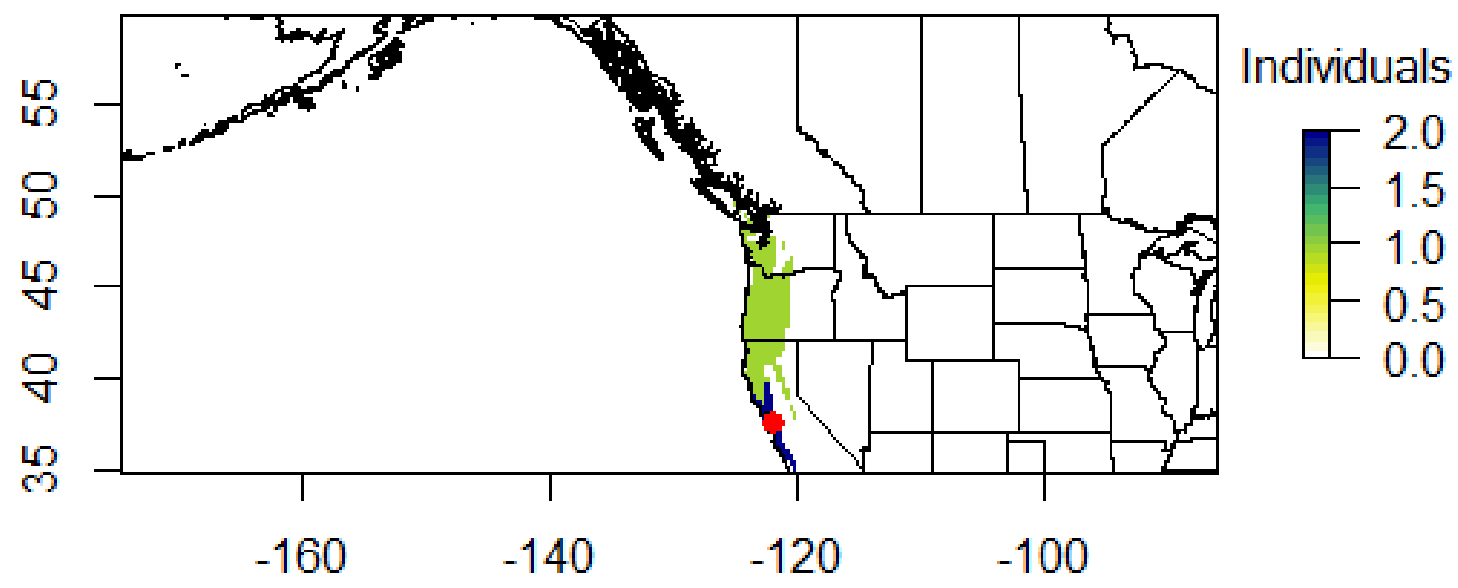


(C)

\section{Week 3}

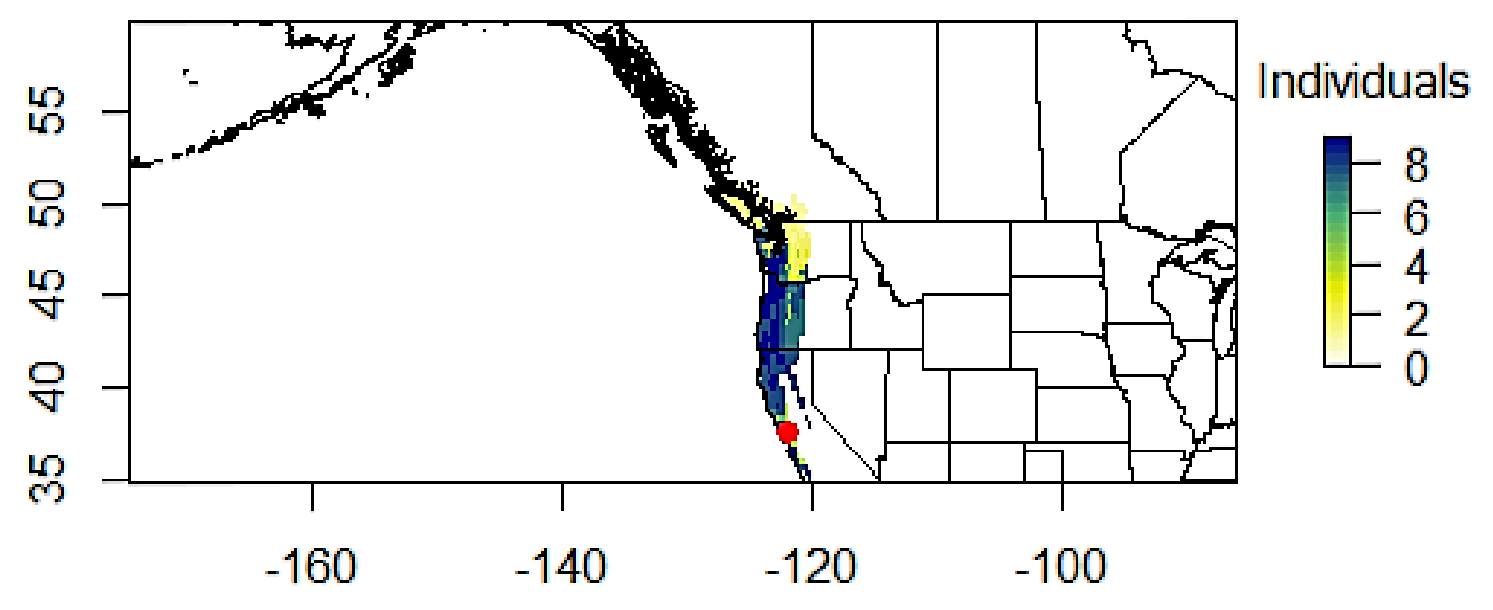

(D)

\section{Week 4}

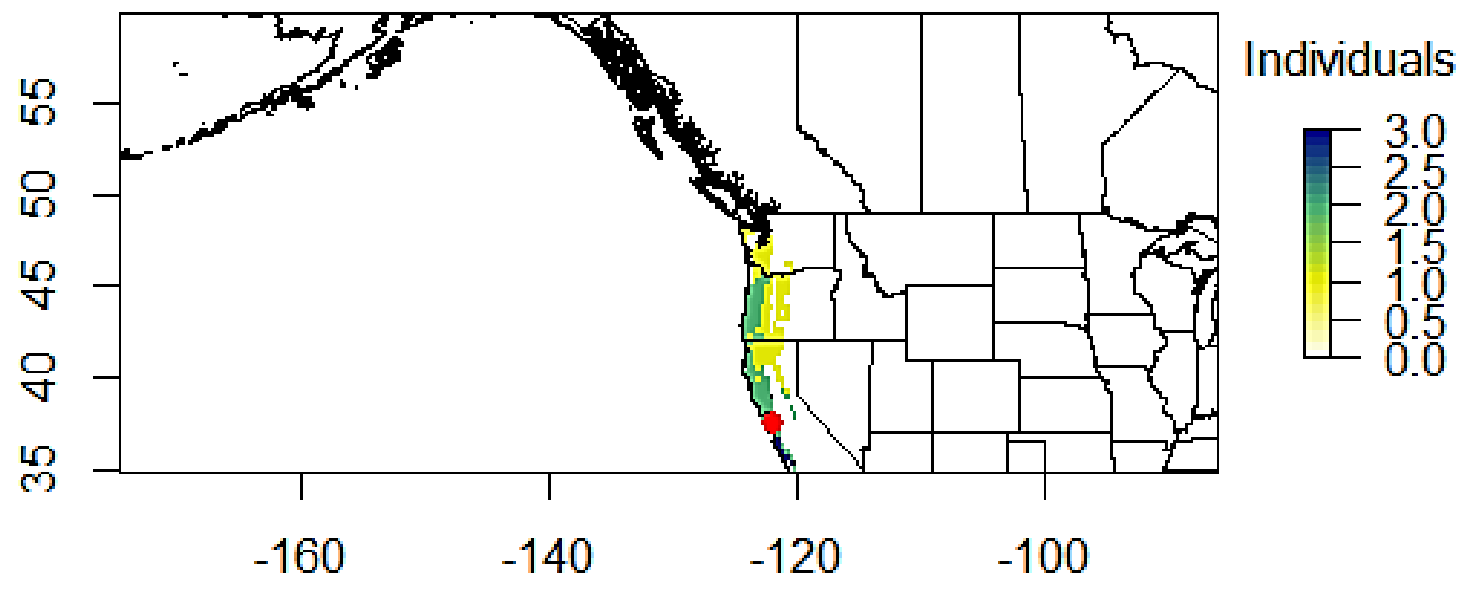


(E)

\section{Week 5}

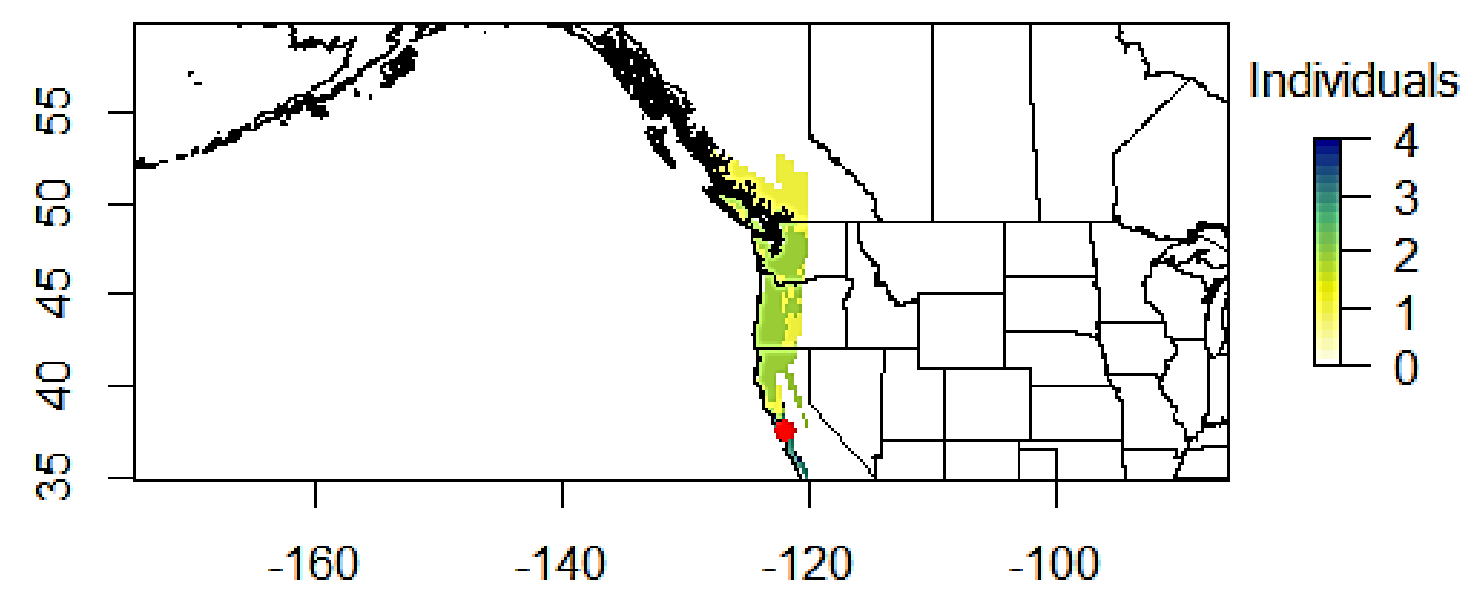

(F)

\section{Week 6}

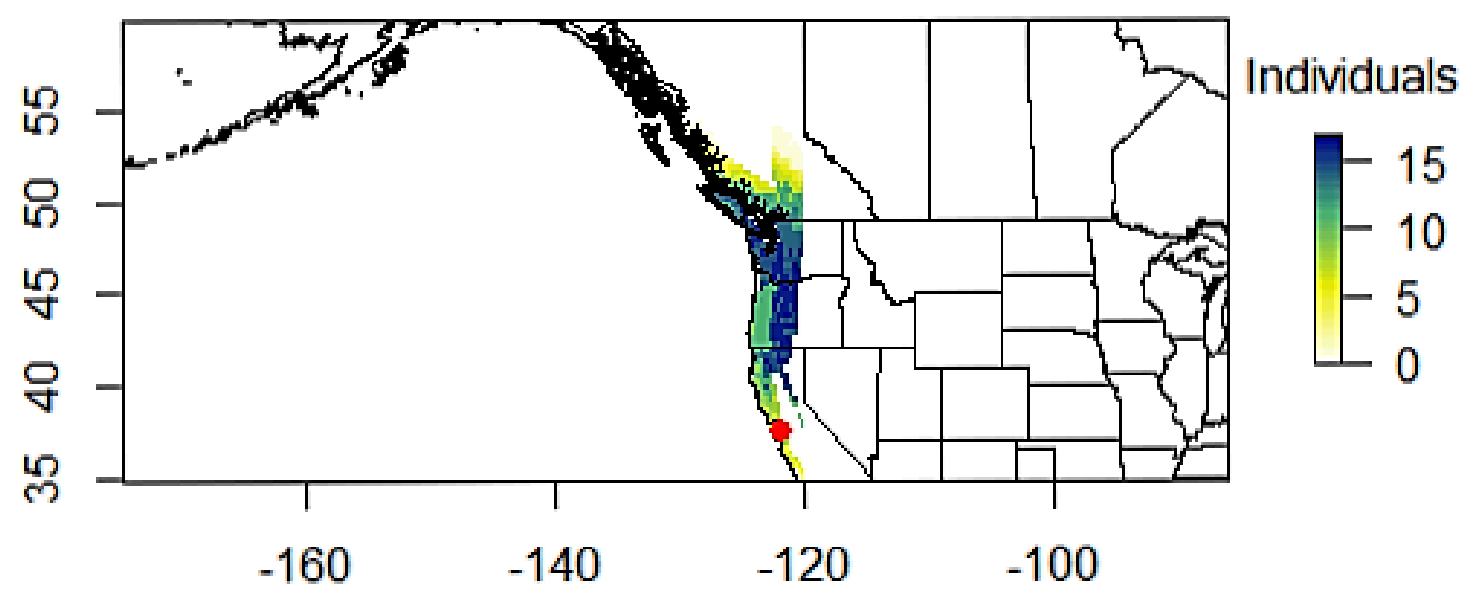


(G)

\section{Week 7}

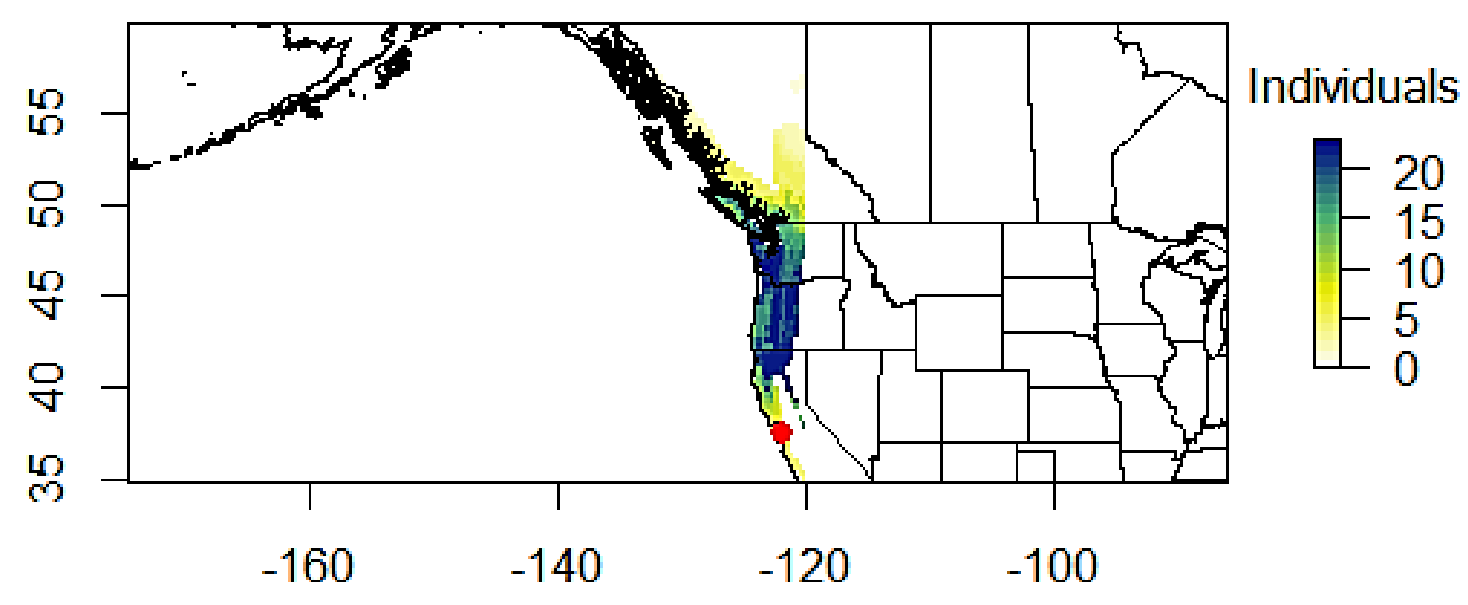

(H)

\section{Week 8}

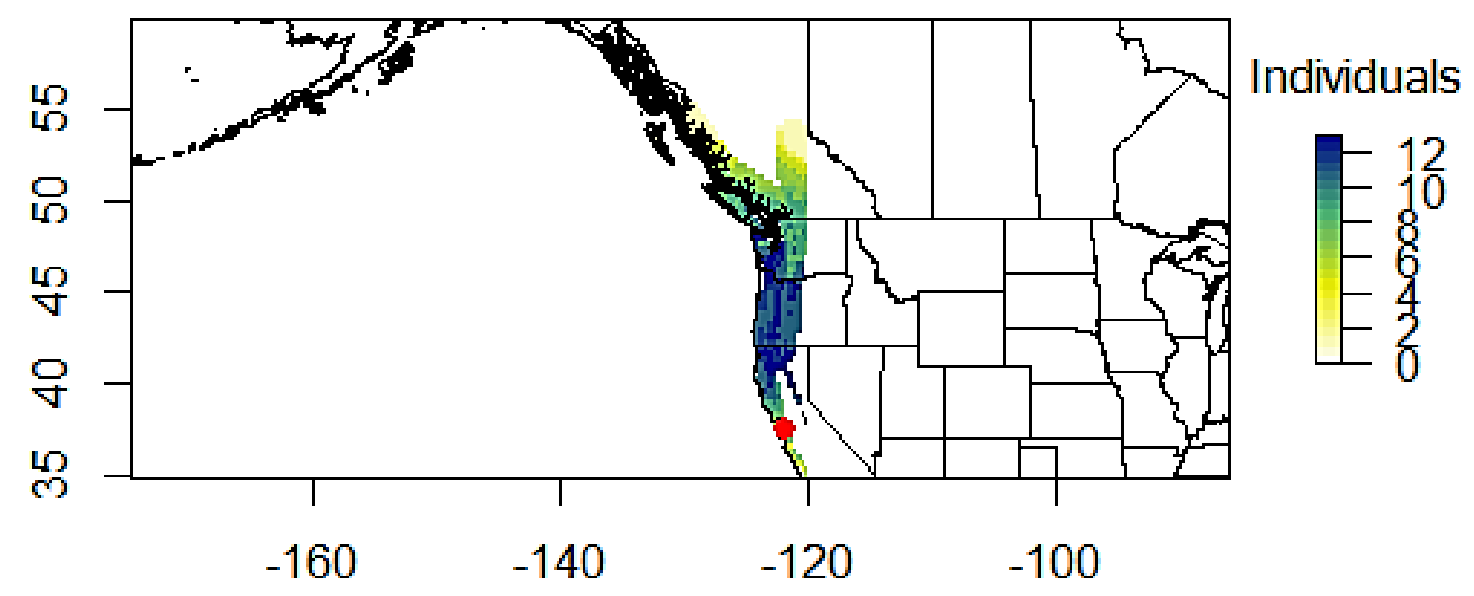


(I)

\section{Week 9}

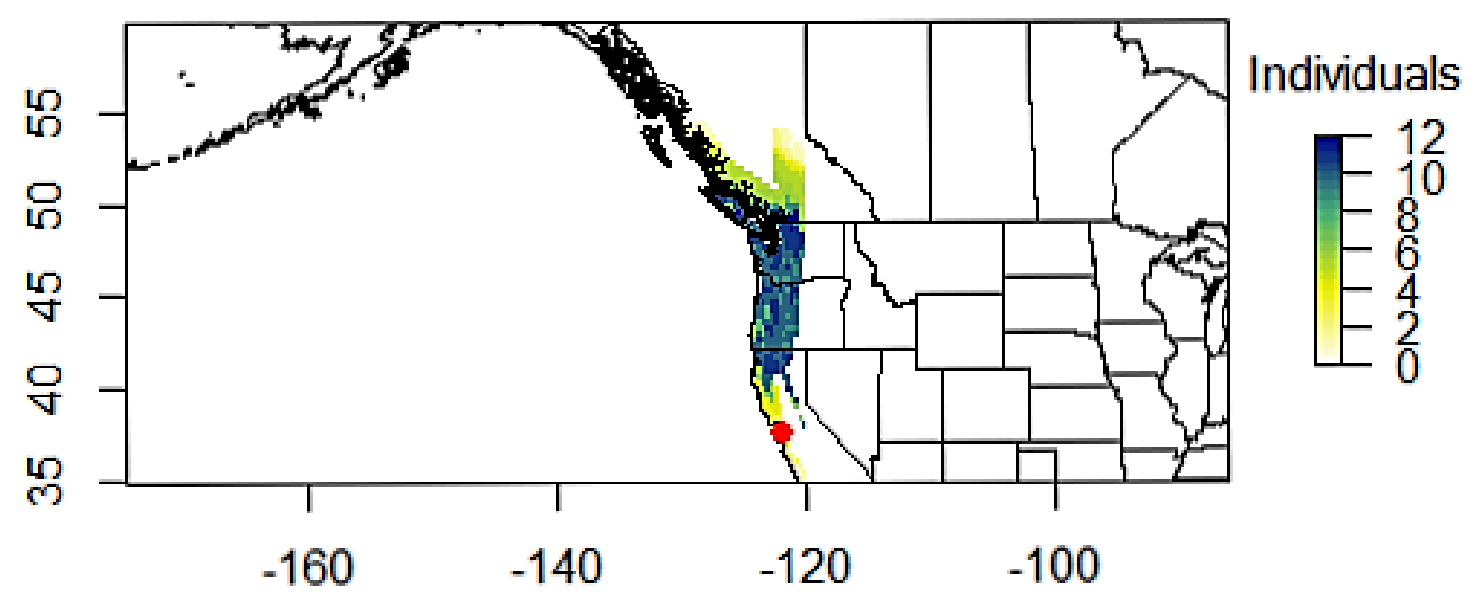

(J)

\section{Week 10}

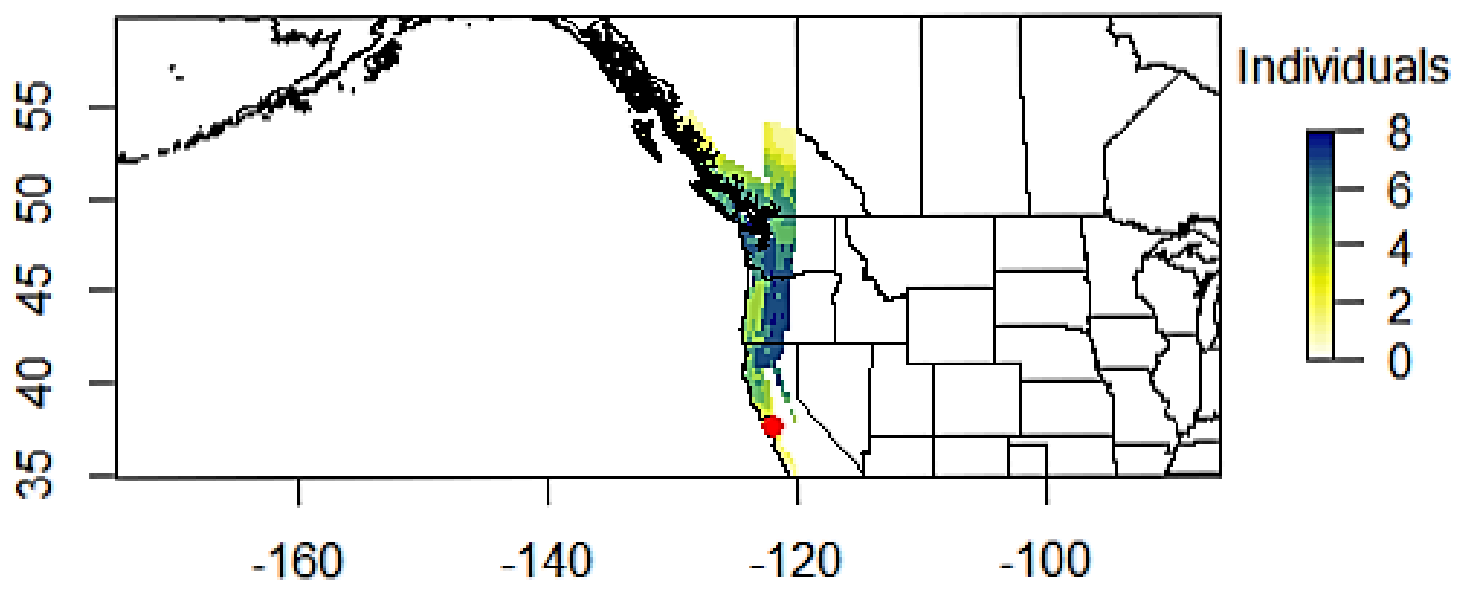


(K)

\section{Week 11}

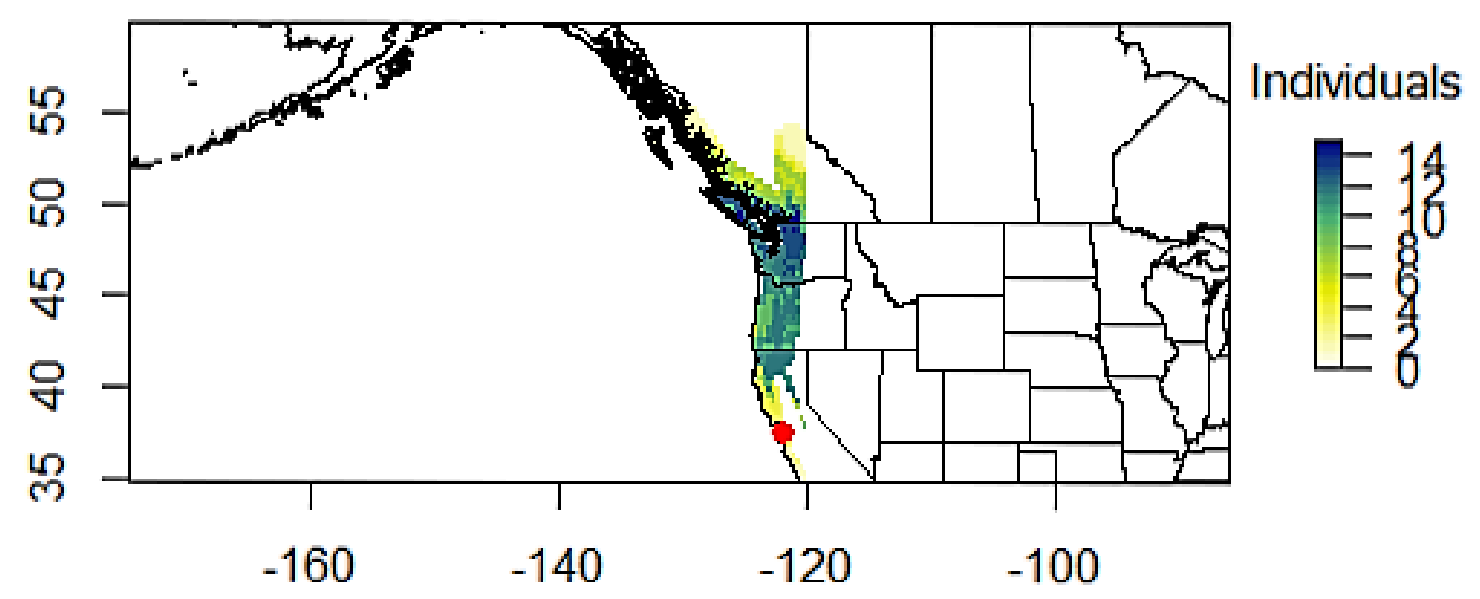

(L)

Week 12

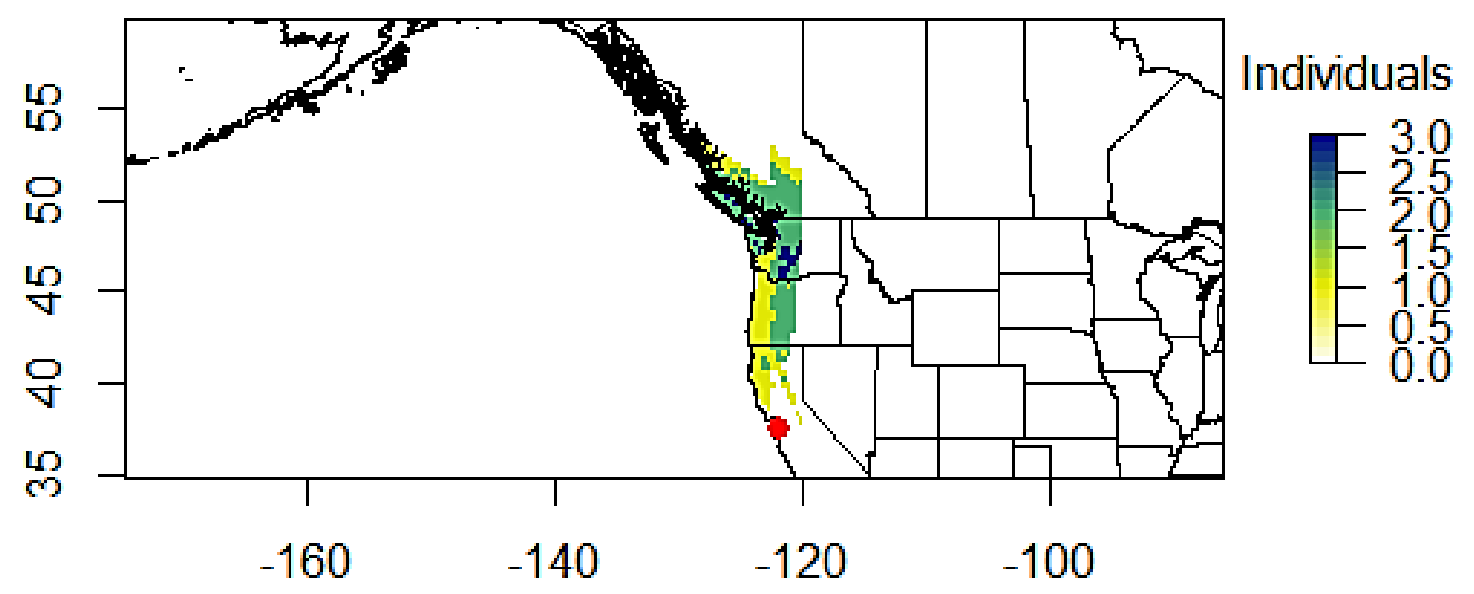




\section{Week 13}

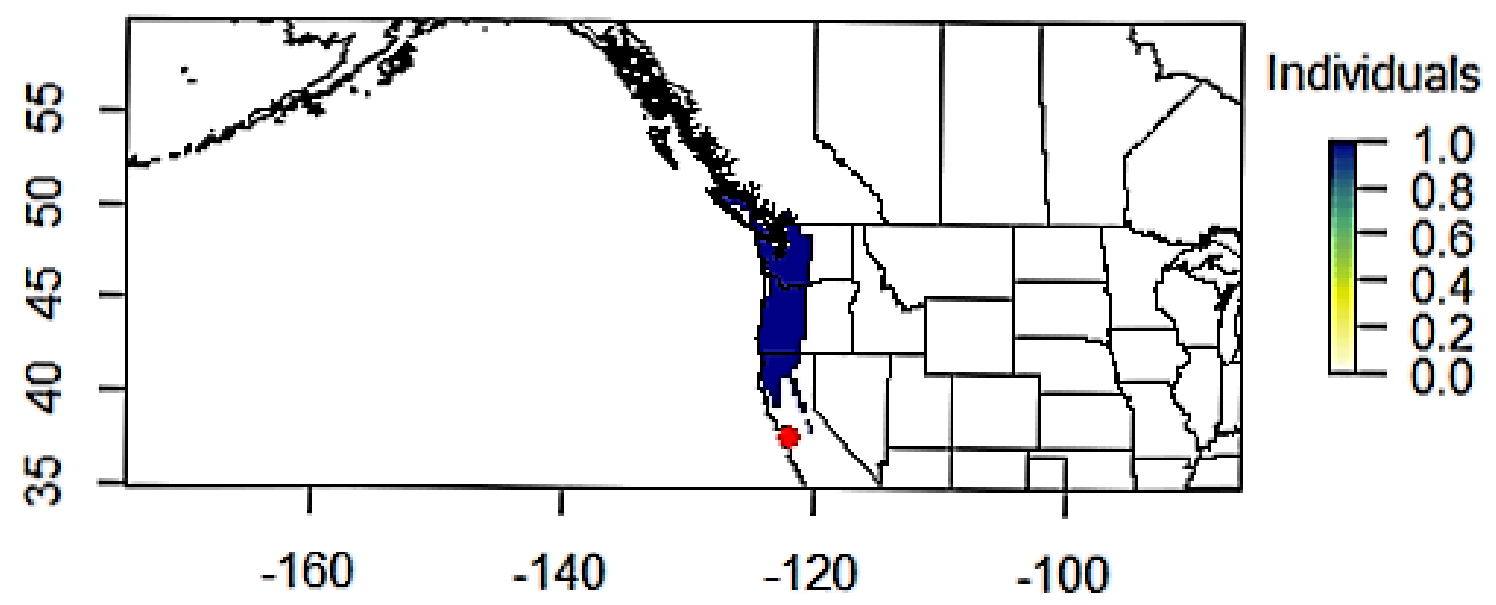

Figure 19. Probable breeding origins of Pacific-slope flycatchers sampled at the Coyote Creek Field Station in Milpitas, California (red dot) from (A) 7/20/2014 to 7/26/2014 $(N=1)$; (B) $7 / 27 / 2014$ to $8 / 2 / 2014$ (N=3); (C) $8 / 3 / 2014$ to $8 / 9 / 2014$ ( $N=17)$; (D) $8 / 10 / 2014$ to $8 / 16 / 2014(N=4)$; (E) $8 / 17 / 2014$ to $8 / 23 / 2014(N=6)$; (F) $8 / 24 / 2014$ to $8 / 30 / 2014$ (N=27); (G) 8/31/2014 to $9 / 6 / 2014$ (N=33); (H) $9 / 7 / 2014$ to $9 / 13 / 2014$ (N=25); (I) $9 / 14 / 2014$ to $9 / 20 / 2014(N=17)$; (J) $9 / 21 / 2014$ to $9 / 27 / 2014(N=12)$; (K) 9/28/2014 to $10 / 4 / 2014$ ( $N=20$ ); (L) $10 / 5 / 2014$ to $10 / 11 / 2014(N=3)$; and (M) $10 / 12 / 2014$ to $10 / 18 / 2014(N=1)$. Each legend scale specifies the number of individual PSFL that had consistent isotopic feather values with pixels on the maps of the same color based on the likelihood-based assignment at 2:1 odds. 
APPENDIX C: Stable isotope values (\%o) of feathers from 167 HY Pacific-slope flycatchers sampled at the Coyote Creek Field Station in Milpitas, California

\begin{tabular}{cccc}
\hline ID & $\delta^{2} \mathrm{H}$ & $\delta^{13} \mathrm{C}$ & $\delta^{15} \mathrm{~N}$ \\
\hline 01 & -71.5 & -21.82 & 5.2 \\
02 & -60 & -22.37 & 6.8 \\
03 & -58 & -21.74 & 5.2 \\
04 & -82.3 & -22.33 & 6.2 \\
05 & -49.9 & -22.92 & 5.8 \\
06 & -52 & -21.83 & 6.1 \\
07 & -80 & -22.7 & 8.2 \\
08 & -51.7 & -21.79 & 7.8 \\
09 & -73 & -23.62 & 5.9 \\
010 & -81.7 & -22.82 & 8.6 \\
011 & -80.2 & -23.43 & 7.9 \\
012 & -94.8 & -24.58 & 8.1 \\
013 & -82.9 & -20.57 & 7.9 \\
014 & -49.6 & -22.32 & 8.4 \\
015 & -46.1 & -21.89 & 7.8 \\
016 & -51.3 & -23.33 & 4.7 \\
017 & -63 & -23.02 & 6.3 \\
018 & -87.5 & -23.49 & 5.7 \\
019 & -80.2 & -21.36 & 6.1 \\
020 & -56.6 & -21.31 & 6.0 \\
021 & -77.1 & -24.04 & 5.6 \\
022 & -78.5 & -22.87 & 6.6 \\
023 & -46.9 & -23.23 & 5.5 \\
024 & -55.3 & -21.04 & 6.1 \\
025 & -69.4 & -22.69 & 8.7 \\
026 & -108 & -22.96 & 6.6 \\
027 & -76.8 & -23.39 & 6.1 \\
028 & -89.2 & -25.39 & 6.2 \\
029 & -55.9 & -24.53 & 4.2 \\
030 & -58.6 & -22.96 & 8.4 \\
031 & -55.2 & -21.4 & 5.1 \\
032 & -63.9 & -22.26 & 5.6 \\
\hline & & &
\end{tabular}


APPENDIX C: Continued

\begin{tabular}{cccc}
\hline $\mathrm{ID}$ & $\delta^{2} \mathrm{H}$ & $\delta^{13} \mathrm{C}$ & $\delta^{15} \mathrm{~N}$ \\
\hline 033 & -93.1 & -23.51 & 7.4 \\
034 & -105.3 & -23.22 & 4.6 \\
035 & -56.9 & -22.35 & 8.1 \\
036 & -102.6 & -23.8 & 4.7 \\
037 & -99.3 & -22.04 & 3.7 \\
038 & -75.4 & -22.88 & 4.5 \\
039 & -98.4 & -22.79 & 6.1 \\
040 & -81.3 & -23.27 & 6.3 \\
041 & -53.6 & -22.82 & 6.9 \\
042 & -68.7 & -22.02 & 5.2 \\
043 & -109.9 & -23.77 & 5.0 \\
044 & -98.5 & -22.37 & 4.8 \\
045 & -98.3 & -22.55 & 4.9 \\
046 & -96.6 & -24.16 & 5.7 \\
047 & -83.2 & -25.69 & 7.3 \\
048 & -108 & -22.59 & 5.5 \\
049 & -78.4 & -22.41 & 5.9 \\
050 & -78.1 & -22.52 & 6.0 \\
051 & -84.4 & -24.47 & 6.6 \\
052 & -90.5 & -22.95 & 6.8 \\
053 & -77.5 & -21.97 & 5.3 \\
054 & -92.3 & -21.99 & 4.2 \\
055 & -119.5 & -23.85 & 7.2 \\
056 & -108 & -23.58 & 4.9 \\
057 & -57.4 & -21.52 & 5.5 \\
058 & -104 & -22.48 & 5.3 \\
059 & -61.2 & -22.38 & 5.3 \\
060 & -97.1 & -24.22 & 4.6 \\
061 & -96.3 & -23.35 & 4.0 \\
062 & -88.7 & -22.93 & 5.1 \\
063 & -77.8 & -23.06 & 6.1 \\
064 & -79.3 & -23.57 & 5.6 \\
065 & -71.4 & -23.01 & 6.6 \\
066 & -80.8 & -23.53 & 3.8 \\
067 & -92.5 & -23.14 & 4.5 \\
\hline & & & \\
053
\end{tabular}


APPENDIX C: Continued

\begin{tabular}{cccc}
\hline $\mathrm{ID}$ & $\delta^{2} \mathrm{H}$ & $\delta^{13} \mathrm{C}$ & $\delta^{15} \mathrm{~N}$ \\
\hline 068 & -99.4 & -23.5 & 5.2 \\
069 & -91 & -23.3 & 5.5 \\
070 & -78.6 & -21.73 & 4.7 \\
071 & -90.6 & -23.88 & 3.5 \\
072 & -96.1 & -23.32 & 4.2 \\
073 & -88 & -23.61 & 4.8 \\
074 & -94.1 & -23.85 & 6.1 \\
075 & -126.6 & -23.2 & 4.7 \\
076 & -93.4 & -23.35 & 3.7 \\
077 & -118.4 & -24.38 & 3.6 \\
078 & -115 & -23.56 & 5.9 \\
079 & -85.5 & -22.57 & 9.2 \\
080 & -99 & -23.49 & 7.1 \\
081 & -82.4 & -22.34 & 6.0 \\
082 & -61.8 & -22.38 & 6.1 \\
083 & -114.5 & -23.15 & 3.6 \\
084 & -85.8 & -20.81 & 11.2 \\
085 & -62.9 & -21.86 & 7.9 \\
086 & -47.7 & -21.83 & 6.4 \\
087 & -108.9 & -23.34 & 4.0 \\
088 & -93.3 & -23.55 & 5.0 \\
089 & -96.5 & -23.03 & 8.8 \\
090 & -84.3 & -22.08 & 5.7 \\
091 & -141.5 & -22.36 & 6.3 \\
092 & -76.7 & -23.06 & 7.4 \\
093 & -88 & -22.18 & 3.1 \\
094 & -59 & -22.04 & 5.8 \\
095 & -98 & -22.84 & 4.7 \\
096 & -72 & -22.36 & 7.5 \\
097 & -57.4 & -21.8 & 4.2 \\
098 & -75.2 & -22.57 & 9.1 \\
099 & -95.5 & -23.29 & 4.8 \\
100 & -64.4 & -22.38 & 7.9 \\
101 & -82.6 & -22.7 & 5.4 \\
102 & -101.1 & -22.68 & 5.1 \\
\hline & & & \\
\hline
\end{tabular}


APPENDIX C: Continued

\begin{tabular}{cccc}
\hline ID & $\delta^{2} \mathrm{H}$ & $\delta^{13} \mathrm{C}$ & $\delta^{15} \mathrm{~N}$ \\
\hline 103 & -38.8 & -21.46 & 5.3 \\
104 & -116 & -19.13 & 8.5 \\
105 & -113.7 & -23.33 & 4.6 \\
106 & -129.9 & -24.25 & 4.0 \\
107 & -88.9 & -23.88 & 7.3 \\
108 & -82.4 & -23.46 & 7.0 \\
109 & -112.3 & -23.61 & 4.5 \\
110 & -104.8 & -23.26 & 5.7 \\
111 & -75.2 & -23 & 7.3 \\
112 & -115.7 & -24.3 & 4.2 \\
113 & -77.4 & -23.58 & 6.1 \\
114 & -104.6 & -23.78 & 4.0 \\
115 & -86.5 & -23.55 & 6.1 \\
116 & -83 & -22.12 & 3.5 \\
117 & -91.7 & -22.96 & 4.8 \\
118 & -106.6 & -23.24 & 5.3 \\
119 & -94.6 & -22.27 & 4.3 \\
120 & -81.7 & -22.56 & 7.0 \\
121 & -94.5 & -24.95 & 5.7 \\
122 & -116.5 & -23.72 & 4.2 \\
123 & -77.2 & -22.78 & 7.5 \\
124 & -113.2 & -23 & 5.6 \\
125 & -93.5 & -22.22 & 4.3 \\
126 & -75.3 & -22.68 & 5.2 \\
127 & -96.2 & -23.23 & 4.2 \\
128 & -121.8 & -22.79 & 8.0 \\
129 & -92.4 & -22.28 & 4.9 \\
130 & -111.9 & -24.4 & 2.4 \\
131 & -92.4 & -22.34 & 5.1 \\
132 & -100.3 & -23.73 & 4.2 \\
133 & -69.1 & -22.49 & 4.5 \\
134 & -104.9 & -22.98 & 4.7 \\
135 & -123.2 & -23.54 & 4.3 \\
136 & -100.3 & -23.51 & 4.9 \\
137 & -79.7 & -23.12 & 6.8 \\
\hline & & & \\
113 &
\end{tabular}


APPENDIX C: Continued

\begin{tabular}{cccc}
\hline ID & $\delta^{2} \mathrm{H}$ & $\delta^{13} \mathrm{C}$ & $\delta^{15} \mathrm{~N}$ \\
\hline 138 & -66.5 & -23.89 & 6.5 \\
139 & -76.3 & -23.05 & 5.7 \\
140 & -96.8 & -23.48 & 5.7 \\
141 & -82.9 & -22.48 & 4.9 \\
142 & -97.6 & -23.47 & 4.4 \\
143 & -85.5 & -22.92 & 4.3 \\
144 & -116.3 & -24.09 & 3.3 \\
145 & -107.4 & -23.63 & 5.0 \\
146 & -92.6 & -24.24 & 3.2 \\
147 & -76.7 & -22.99 & 5.4 \\
148 & -82.2 & -22.59 & 3.2 \\
149 & -92 & -22.73 & 3.7 \\
150 & -116.1 & -23.54 & 4.4 \\
151 & -98.2 & -23.43 & 4.1 \\
156 & -116.1 & -23.58 & 5.5 \\
157 & -128.4 & -22.13 & 6.8 \\
158 & -95.8 & -23.79 & 1.6 \\
161 & -70.8 & -24.34 & 5.8 \\
162 & -93.8 & -23.18 & 3.8 \\
163 & -100.5 & -24.85 & 4.6 \\
164 & -112.2 & -23.42 & 5.6 \\
165 & -92.7 & -23.24 & 5.1 \\
166 & -77.3 & -23.34 & 4.8 \\
167 & -106.5 & -22.85 & 4.5 \\
168 & -93.3 & -23.51 & 3.0 \\
169 & -109.8 & -23.95 & 5.3 \\
170 & -84.8 & -23.79 & 5.4 \\
171 & -102.1 & -23.77 & 4.4 \\
174 & -109.8 & -25.32 & 3.9 \\
175 & -90.8 & -24.7 & 6.3 \\
\hline & & &
\end{tabular}

